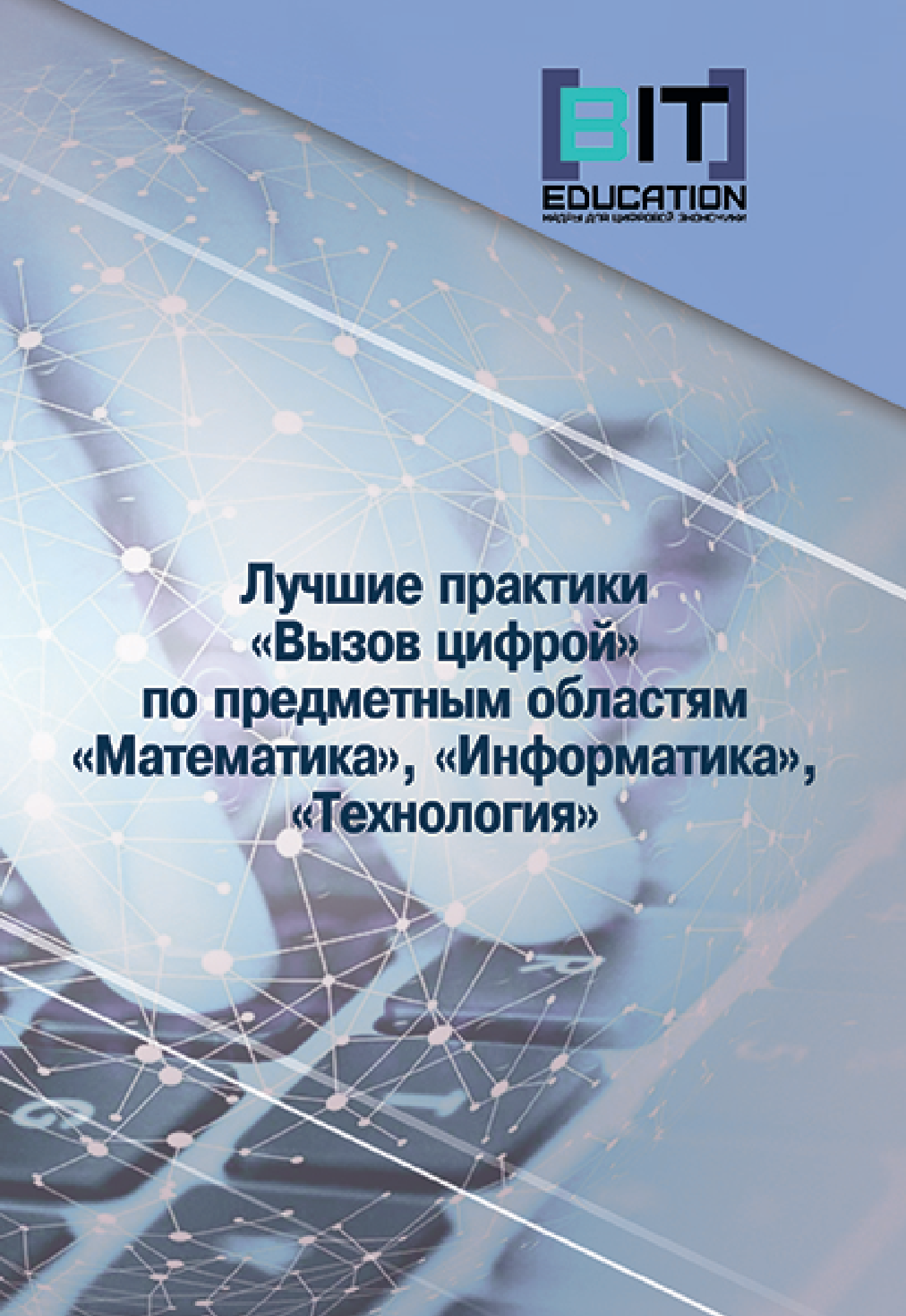


Муниципальное бюджетное общеобразовательное учреждение «Средняя общеобразовательная школа №12» города Чебоксары Чувашской Республики

\section{ЛУЧШИЕ ПРАКТИКИ «ВЫЗОВ ЦИФРОЙ» ПО ПРЕДМЕТНЫМ ОБЛАСТЯМ «МАТЕМАТИКА», «ИНФОРМАТИКА», «ТЕХНОЛОГИЯ» \\ Методическое пособие}

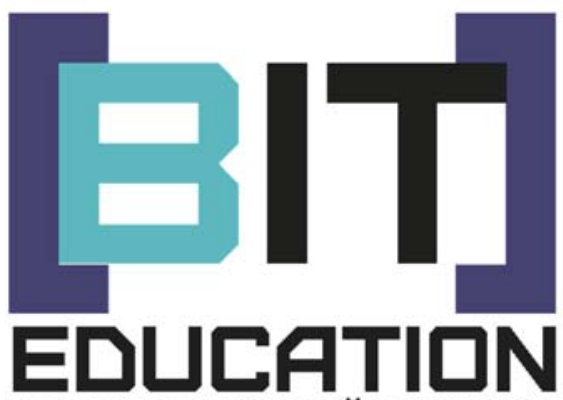

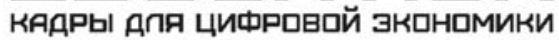

Чебоксары

«Интерактив плюс»

2020 


\title{
УДК 373
}

ББК 74.26

Л87

Выполнено при финансовой поддержке Министерства просвещения РФ в рамках Соглашения №073-15-2020-1400 от 22.06.2020 г.

Рецензенты: Жданова Светлана Николаевна - д-р пед. наук, профессор ФГБОУ ВО «Оренбургский государственный педагогический университет»,

Попова Инна Григорьевна, канд. физ.-мат. наук, доцент ФГБОУ ВО «Донской государственный технический

Редакционная университет»

коллегия:

Мочалова Елена Алексеевна, директор МБОУ «СОШ №12» г. Чебоксары

Андреева Татьяна Юрьевна, заместитель директора МБОУ «СОШ №12» г. Чебоксары

\section{Дизайн \\ обложки: Фирсова Надежда Васильевна, дизайнер}

Л87

\begin{abstract}
Лучшие практики «Вызов цифрой» по предметным областям «Математика», «Информатика», «Технология» : методическое пособие / редкол.: Е.А. Мочалова, Т.Ю. Андреева. - Чебоксары: «Интерактив плюс», 2020. - 92 с.
\end{abstract}

\section{ISBN 978-5-6045742-1-8}

В методическом пособии представлены научные публикации, посвященные вопросам деятельности образовательных организаций в сфере формирования цифровых навыков. В материалах пособия приведены результаты теоретических и прикладных изысканий представителей научного и образовательного сообщества в данной области.

Статьи представлены в авторской редакции.

ISBN 978-5-6045742-1-8

DOI $10.21661 / \mathrm{a}-752$
(C) МБОУ «СОШ №12» г. Чебоксары, 2020

(C) «Интерактив плюс», оформление, 2020 


\section{СОДЕРЖАНИЕ}

Предисловие 5

ЛУЧШИЕ ПРАКТИКИ ОБУЧЕНИЯ «ВЫЗОВ ЦИФРОЙ» ПО ПРЕДМЕТНОЙ ОБЛАСТИ «МАТЕМАТИКА»

Алексей Ю.В. Электронные образовательные ресурсы и их применение на уроках математики

Белова Е.И. Применение цифровых технологий на уроках математики 11

Волкова C.H., Сивак E.E. Применение метода наименьших квадратов к подбору производственных функций.. 14

Глебова М.B. Требования к проведению дистанционного тестирования по математике в цифровой образовательной среде 23

Глебова М.В., Хрянина И.М. Использование возможностей cepвиса Google Classroom для организации дистанционного практико-ориентированного обучения математике 26

Демина Н.В., Сабанова Л.В., Глинкина Е.В. Практика выявления уровня сформированности познавательных УУД у младших школьников на внеклассных занятиях по математике средствами электронных образовательных ресурсов 30

Ezорова K.B. Профильная направленность обучения математике в условиях среднего профессионального образования................. 36

Елизарова Е.Ю., Красильникова С.В. Интерполяционные формулы Ньютона как основа численного дифференцирования ... 40

Кораблева Д.А. Технологии достижения метапредметных результатов во внеклассной работе по математике у подростков в условиях дистанционного обучения ….................................. 48

Мотрюк E.H. Преподавание высшей математики в вузе

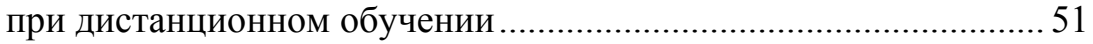

Пономарева Ю.A. Роль информационных технологий в обучении математике ................................................................ 55

Попова T.A. Роль методов математики в обучении программированию 58

Шакирова Р.В. Электронные образовательные ресурсы как средство обучения дискретной математике 61 


\section{ЛУЧШИЕ ПРАКТИКИ ОБУЧЕНИЯ «ВЫЗОВ ЦИФРОЙ» ПО ПРЕДМЕТНОЙ ОБЛАСТИ «ИНФОРМАТИКА»}

\section{Анетова А.Ж., Тулегулов А.Д., Еипанов В.С. Развитие} обучающихся в процессе разработки творческих компьютерных проектов в условиях дополнительного образования на факультативных занятиях по предмету «Информатика»

Бахматова С.В., Иванова И.П. Уроки информатики как средство развития информационной культуры......................6 67

Бахмисова М.A. Внедрение 3D-технологий в образовательную деятельность: время готовить инженеров будущего.................... 72

Дорофеев A.C., Сосинская С.C. Разработка модуля для индивидуализации процесса обучения в Moodle 76

Дудковская И.А. Электронное учебное пособие как способ развития познавательных универсальных учебных действий обучающихся на уроках информатики ....................................8 80

\section{ЛУЧШИЕ ПРАКТИКИ ОБУЧЕНИЯ «ВЫЗОВ ЦИФРОЙ» ПО ПРЕДМЕТНОЙ ОБЛАСТИ «ТЕХНОЛОГИЯ»}

Никифорова О.В. Эффективное использование ИКТ на уроках технологии в современных условиях

Сергеева A.A. Реализация межпредметных связей в рамках предметной области «Технология» в условиях цифровизации образовательного процесса 86 


\section{ПРЕДИСЛОВИЕ}

Муниципальное бюджетное общеобразовательное учреждение «Средняя общеобразовательная школа №12» города Чебоксары Чувашской Республики представляет методическое пособие «Лучшие практики «Вызов цифрой» по предметным областям «Математика», «Информатика», «Технология». Методическое пособие выпущено по итогам реализации проекта «Платформа ЦифроРИТМ» в рамках федерального проекта «Кадры для цифровой экономики» национальной программы «Цифровая экономика Российской Федерации» государственной программы Российской Федерации «Развитие образования», выполненного в соответствии с Соглашением №073-15-2020-1400 от 22.06.2020 г. с Министерством просвещения Российской Федерации о предоставлении гранта из федерального бюджета в форме субсидии на развитие и распространение лучшего опыта в сфере формирования цифровых навыков образовательных организаций, осуществляющих образовательную деятельность по общеобразовательным программам, имеющим лучшие результаты в преподавании предметных областей «Математика», «Информатика» и «Технология».

В методическом пособии представлены научные публикации, посвященные вопросам деятельности образовательных организаций в сфере формирования цифровых навыков. В материалах пособия приведены результаты теоретических и прикладных изысканий представителей научного и образовательного сообщества в данной области.

Цифровизация - это вызов современности. Сейчас как никогда необходимо совершенствовать образовательный контент, развивать компьютерную грамотность и цифровые навыки, повышать познавательную мотивацию учащихся и уровень самообразования педагогов.

Данное методическое пособие создано с целью создания и распространения апробированного методического комплекса рекомендаций по организации занятий в подопечных школах с целью внедрения лучших практик обучения по предметным областям «Математика», «Информатика» и «Технология», а также создания в МБОУ «СОШ №12» г.Чебоксары условий для формирования понимания значимости развития цифровых навыков и образовательных технологий с последующей диссеминацией позитивного опыта.

Редакционная коллегия выражает глубокую признательность нашим уважаемым авторам за активную жизненную позицию, желание поделиться уникальными разработками и проектами, публикацию в методическом пособии Лучшие практики «Вызов цифрой» по предметным областям «Математика», «Информатика», «Технология», содержание которого не может быть исчерпано. 


\title{
ЛУЧШИЕ ПРАКТИКИ «ВЫЗОВ ЦИФРОЙ» ПО ПРЕДМЕТНОЙ ОБЛАСТИ «МАТЕМАТИКА»
}

\author{
Алексей Юлия Вадимовна \\ преподаватель \\ ГБПОУ Ростовской области \\ «Константиновский педагогический колледж» \\ г. Константиновск, Ростовская область
}

\section{ЭЛЕКТРОННЫЕ ОБРАЗОВАТЕЛЬНЫЕ РЕСУРСЫ И ИХ ПРИМЕНЕНИЕ НА УРОКАХ МАТЕМАТИКИ}

Аннотация: в статье рассмотрены некоторые аспекты информационных технологий на уроках математики. Автором представлень наблюдения и выводы, полученные в ходе работы.

Ключевые слова: электронные образовательные ресурсы, уроки математики.

Учитель, работающий в инновационном режиме, использует в своей работе разнообразные обучающие технологии, в том числе компьютерные. Они эффективны в том случае, если педагог является настоящим профессионалом в своей предметной области, имеет специальные знания и умения для работы с применением компьютерных технологий; кабинеты оснащены достаточным количеством современных ТСО; приобретены или созданы методически обоснованные, качественные учебные компьютерные программы.

Эффективность интерактивных методов обучения еще не исследована в полной мере. На основании приобретенного за годы работы опыта я хотела бы представить некоторые мои наблюдения и выводы.

Активное использование электронных образовательных ресурсов приводит к необходимости перестройки учебного процесса.

Урок - введение нового материала в традиционной форме теряет свою актуальность. Ученики получают больше новой информации исходя из самостоятельной деятельности, нежели чем на обычном уроке. Во время самостоятельной работы учащиеся осваивают содержание ЭОР. Работа с интернет-ресурсами и другими информационными ресурсами: электронными библиотеками, справочниками, графическими конструкторами и так далее.

Рассмотрим некоторые модели обучения, реализованные различными типами уроков.

\section{Урок-введение нового материала}

с использованием ЭОР при ведущеей роли учителя

На таких уроках применяются электронные учебные модули информационного типа. Учащиеся воспринимают информацию, сообщаемую учителем. Учитель, в свою очередь, объясняет новый материал, используя материалы ЭУМ как основу для презентации.

При формулировании учителем заданий могут использоваться ЭУМ практического типа. Учащиеся знакомятся с заданием и задают вопросы

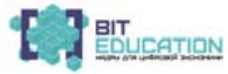


по его усвоению. Учитель же определяет ЭУМ П-типа; при наличии вариативных ЭУМ П-типа определяет их индивидуально для каждого учащегося.

При выполнении заданий учащимися используются ЭУМ П-типа. После выполнения заданий учащиеся могут размещать результаты его выполнения на форуме. Учитель анализирует результаты выполнения заданий.

При формулировании контрольного вопроса или задания используются ЭУМ контрольного типа (К-типа). Учащиеся знакомятся с заданиями, а учитель определяет ЭУМ К-типа; при наличии вариативных ЭУМ К-типа определяет их индивидуально для каждого учащегося. Далее, после выполнения учащимися контрольного задания учитель анализирует ответы учащихся, оценивает их деятельность.

Урок-введение нового материала с использованием ЭОР и самостоятельной деятельности учащихся

Таблица 1

\begin{tabular}{|c|l|l|l|l|}
\hline № & \multicolumn{1}{|c|}{ Этап урока } & Содержание & \multicolumn{1}{|l}{$\begin{array}{c}\text { Деятельность } \\
\text { учащихся }\end{array}$} & $\begin{array}{l}\text { Деятельность } \\
\text { учителя }\end{array}$ \\
\hline 1 & $\begin{array}{l}\text { Изучение нового } \\
\text { материала }\end{array}$ & ЭУМ И-типа & $\begin{array}{l}\text { Знакомятся с } \\
\text { содержанием }\end{array}$ & $\begin{array}{l}\text { Определяет } \\
\text { ЭУМ, при } \\
\text { наличии }\end{array}$ \\
\hline 2 & $\begin{array}{l}\text { Формирование } \\
\text { вопросов } \\
\text { учащимися } \\
\text { учителю по } \\
\text { изученному }\end{array}$ & $\begin{array}{l}\text { Вопросы } \\
\text { учеников }\end{array}$ & $\begin{array}{l}\text { Задают вопросы } \\
\text { учителю }\end{array}$ & $\begin{array}{l}\text { Отвечает на } \\
\text { вопросы } \\
\text { учащихся }\end{array}$ \\
\hline 3 & $\begin{array}{l}\text { Ответы учащихся } \\
\text { на вопросы }\end{array}$ & $\begin{array}{l}\text { Вопросы } \\
\text { учителя }\end{array}$ & $\begin{array}{l}\text { Отвечают на } \\
\text { вопросы учителя }\end{array}$ & $\begin{array}{l}\text { Задает } \\
\text { вопросы по } \\
\text { изученному } \\
\text { материалу }\end{array}$ \\
\hline
\end{tabular}

Урок-решение задач

Основной целью такого урока будет являться формирование новых методов и способов решения задач исходя из изученных теоретических материалов. Этот урок может быть в индивидуальной и групповой форме.

Основой таких уроков являются электронная учебная модель (ЭУМ) практического типа (П-типа), которая содержит задания с решением неалгоритмического характера. Решение таких заданий предполагают осуществления поиска. Электронный учебный модуль практического типа определяет учитель.

Используются также ЭУМ информационного типа (И-типа). Они включают в себя необходимые сведения для решения задач. При этом учитель может рекомендовать определенные ЭУМ И-типа, а может предложить учащимся самостоятельно найти ЭУМ, включающие в себя необходимые сведения.

\section{Проектная деятельность учащихся}

Несомненно, умение осуществлять деятельность по выполнению учебного проекта является интегрированным умением, включающим в себя:

- личный опыт и его анализ;

- формулирование цели;

- формирование задач; 
- план деятельности;

- поиск информации и ее анализ;

- применение усвоенных знаний на практике, для решения конкретных задач;

- умение осуществлять самоанализ и рефлексию;

- презентация собственных исследований и результатов.

Электронные образовательные ресурсы могут быть основой такой деятельности. При этом электронные учебные модули всех типов могут являться в качестве основы. Выбор модулей осуществляется учащимися.

Взятые сами по себе информационные технологии прекрасны, но бесполезны. Необходимо связать воедино содержание преподаваемого предмета, инновационные педагогические и компьютерные технологии. Работая по учебникам таких авторов, как М.Л. Галицкий, Д.А. Терешин, А.Д. Александров, В.И. Рыжик, И.Ф. Шарыгин и др., и при этом применяя на уроках электронные образовательные ресурсы (далее ЭОР), нельзя нарушать концептуальное содержание учебников. Но для того, чтобы внести элемент новизны в эти учебники, ориентированные в большей степени на репродуктивное обучение, требуется большая подготовительная работа как по освоению функций интерактивной доски и компьютерных программ, так и по созданию материалов для работы с ними. Таким образом, освоив создание презентаций в Power Point и научившись создавать качественные уроки на Smart-доске, я пришла к необходимости создать методическую копилку своих уроков и проектов своих учеников, которая практически ежедневно пополняется. Наиболее удачные уроки, созданные во время подготовки к занятиям, я помещаю в эту копилку. После апробации уроков иногда возникает необходимость внести некоторые изменения. Тем самым моя методическая копилка совершенствуется. В нее входят набор задач к урокам, различный справочный материал, презентации и уроки на Smart-доске.

В преподавании математики и, в особенности, тех ее разделов, которые относятся к конструктивной геометрии, математическому анализу, требуется большое количество иллюстраций. Современные информационные технологии позволяют с помощью компьютера создать ряд новых преимуществ при организации иллюстративной поддержки в преподавании предмета. Новыми преимуществами являются: возможность остановок в непрерывном процессе построения изображения, возможность возврата к более ранним стадиям процесса, возможность установки имеющихся материалов в информационных сетях разного уровня (что обеспечивает широкий доступ к ним) и, наконец, возможность использования мультимедийных технологий для анимации и озвучивания тех или иных фрагментов процесса обучения.

Таким образом, с помощью средств интерактивной доски мною созданы: коллекция геометрических фигур, коллекция графиков функций и их производных, видеоролики, видеоуроки, тесты и т. д.

\section{Коллекиия геометрических фигур}

Все чертежи фигур интерактивны. При необходимости фигуру можно увеличить или уменьшить, двигать ее относительно системы координат, обсуждая с учениками правильный и удобный ее выбор. Хотелось бы отметить, что к каждому чертежу существует видеофрагмент, показывающий, как правильно выполнить построение фигуры. При этом ни чертежи, ни 
видеоролики не заменяют кропотливой работы учителя над формированием навыков построения чертежа учениками и их работу над построением на доске. Выбор учителя зависит от целей и задач урока или его этапов.

Коллекция графиков функций и из производньх

К графикам функций созданы видеоролики, демонстрирующие различные свойства функций и их графиков, позволяющие наблюдать, например, за движением касательных. Это позволяет просматривать иллюстрации в интерактивном представлении (движение графиков, совмещение различных частей чертежа), что делает урок наглядным: появляется возможность в очень доступной форме обсуждать свойства функций, использовать материал в большем количестве, что способствует лучшему усвоению темы урока. Все они находятся во вложениях доски и на любом уроке в нужный момент могут быть продемонстрированы обучающимся. Ученики на своих персональных компьютерах проверяют правильность построения графика; кроме того, компьютер помогает определиться в путях решения сложных задач. Безусловно, ЭОР не исключают традиционной деятельности обучающихся, но очевидно, что они улучшают качество выполняемой работы.

Кроме того, на уроках используется и коллекция самой доски. В качестве примера можно привести тригонометрический круг и интерактивный график, вид которого зависит от введенных параметров.

Видеоролики. В работе активно использую и видеоролики, которые созданы по самым различным темам школьной программы: «Построение перпендикуляра к плоскости», «Исследование функций на монотонность и экстремумы», «Решение задач на построение» и др.

Например, к теме урока «Расстояние от точки до плоскости» (как и ко многим другим фрагментам различных уроков) с помощью средств интерактивной доски записан звуковой видеоролик. Это очень удобно: можно несколько раз продемонстрировать построение, в частности, перпендикуляра к плоскости и использовать потом на любом уроке (он хранится в создаваемой учителями коллекции доски), можно во время его показа ходить по классу и показывать ребятам затрудняющие их построения. Большую помощь обучающимся 7 класса оказали видеоролики, созданные к задачам на построение.

Мною созданы и звуковые видеоролики математических диктантов по различным темам школьного курса математики. Не занимаясь непосредственно диктовкой во время урока, учитель имеет возможность ходить по классу, следить за качеством выполнения заданий и в конце диктанта тут же провести полный анализ ошибок.

Ребята могут работать с записями и самостоятельно, поскольку они легко транспортируются на электронные носители или электронную почту.

\section{Видеоуроки}

В качестве примера рассмотрим урок по теме: «Задачи на сравнение объемов многогранников». Это сложная тема. Зачастую обучающимся трудно увидеть, на какие части необходимо разбить многогранник при решении задачи. С помощью средств доски удается наглядно показать, как это делается, что существенно облегчает понимание материала. 


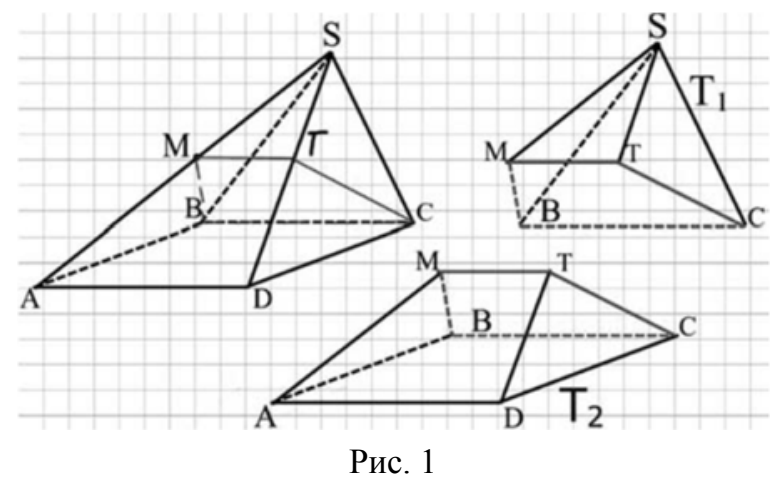

Tecmbl

Обучающие тесты, созданные на SmartBoard

Программа Notebook установлена на персональные компьютеры обучающихся. Тесты составлены таким образом, что ребята не только отвечают на вопросы, но и получают консультации трех уровней. Каждый обучающийся работает в своем темпе, учитель при необходимости помогает, осуществляя тем самым индивидуальный подход к ребятам. Такие тесты помещаются в сеть гимназии. Ребята имеют возможность индивидуально работать на уроке и тренироваться в компьютерном классе. Обучающие тесты могут быть использованы как при изучении нового материала, так и при подготовке к ЕГЭ.

Контролируюшие тесть, созданные на SmartBoard

Работая по контролирующим тестам, все необходимые дополнительные построения, вычисления, записи обучающиеся выполняют на своих персональных компьютерах, которые объединены в локальную сеть, тем самым учитель имеет возможность следить за работой каждого и очень быстро оценить результат этой работы. После получения отметки ребята вновь работают на своих компьютерах, выполняя работу над ошибками, получая индивидуальные консультации учителя.

Тематические тесты, программы 1C «Математика 5-11»

Во время работы обучающихся над тематическими тестами учитель видит у себя на компьютере результаты решения задач каждого обучающегося: верно ли выполнено задание, количество попыток, время работы над заданием, ошибки.

\section{Исследовательская деятельность учащихся}

Тенденции последнего времени таковы, что математика становится экспериментальной наукой. Об этом неоднократно говорилось и на различных конференциях учителей, и на Всероссийском съезде учителей математики. Поэтому роль эксперимента все больше и больше увеличивается и в школе, чему в большой степени способствует наличие персональных компьютеров. Проводя эксперименты, ребята формулируют различные утверждения, догадываются о результатах решения задач, которые потом должны строго обосновать.

Экспериментальную работу учащиеся выполняют в программе MathCad.

Результат этой работы позже оформляется в презентации Power Point, в которую включены созданные обучающимися видеоролики. 
Таким образом, рассмотрев некоторые аспекты информационных технологий на уроках математики, можно говорить о необходимости и пользе их применения. У учителя появляется возможность мгновенно реагировать на ошибки учеников и проводить оперативный контроль знаний в таких формах, как тестирование, сканирование работ. Происходит индивидуализация процесса обучения - дифференцированный подход к выбору материала, индивидуальные подходы при оценке результатов. Ученики активнее вовлекаются в процесс обучения, создавая собственные презентации и видеоролики. Такой вид деятельности способствует развитию логического и творческого мышления, формирует исследовательские навыки при выполнении творческих заданий.

Надо понимать, что ЭОР - это всего лишь инструменты в руках учителя. И от того, каким образом они будут применены, зависит качество обучения. Если ЭОР освоены на достаточно высоком уровне, то они становятся незаменимым помощником, положительно влияющим на уровень знаний, о чем убедительно свидетельствуют результаты моих учеников.

Белова Елена Ивановна

учитель

МБОУ «СОШ №42»

г. Чебоксары, Чувашская Республика

\section{ПРИМЕНЕНИЕ ЦИФРОВЫХ ТЕХНОЛОГИЙ НА УРОКАХ МАТЕМАТИКИ}

Аннотация: автор полагает, все дети способны по-своему. Важно их направить не на получение определенного объема знаний, а на развитие логического мышления, творческих способностей, самостоятельного осмысления и воспитать стремление получать новые знания на основе современных цицрровых образовательных технологий.

Ключевые слова: образовательные платформы, логические задачи, олимпиадные задачи.

Работая учителем математики, часто новый учебный год начинаю со знакомства вновь поступившими пятиклассниками. Поразительно, с каким желанием и неподдельным интересом мальчишки и девчонки работают на уроках. 5-й класс - это новая ступень в жизни ребенка, в каком-то смысле второе рождение. И очень часто на уроках наряду с повторением материала предлагаю решать примеры и упражнения из образовательной платформы «Учи.ру», выводя их на проекторе. Мне интересно: «Кто попытается решить? Кто справится? Кто активно поднимет руку, а скажет только какую-нибудь нелепость?» И знаете, всегда найдется такой ученик, который интересно ответит, предложит свой способ решения. Я для себя делаю вывод: этот пятиклассник будет любить математику, будет решать нестандартные задачи, тем более, по новым цифровым технологиям.

Великий русский писатель и учитель Л.Н. Толстой сказал: «Детей не отпугнешь суровостью, они не переносят только лжи». Только творческий диалог, личностная заинтересованность участников воспитательного процесса создадут благоприятные условия для воспитания творческой личности. Поэтому мое обучение направлено на сотрудничество, на сознательное отношение к учебе. 
Хочется опять привести слова великого классика: «Дело не в том, чтобы знать много, а в том, чтобы знать из всего того, что можно знать, самое нужное». Для этого учитель должен помогать увидеть сущность понятия, приемы или методы решения, их структуру; раскрывать взаимосвязь между родственными понятиями, их свойствами и признаками; нацеливать школьников на их самостоятельное выделение; тщательно вскрывать взаимосвязь между прямыми и обратными действиями. Необходимо вырабатывать у учащихся умение определять главное в рассуждении, избегать многословности, но при этом кратко и логически грамотно пояснять каждый этап решении задач.

Как же продолжить развитие способных к математике детей в условиях одного класса? В первую очередь, я таких учеников выделяю в одну группу, сажаю за учительский компьютер. Так как способные дети новую тему понимают сразу, они могут вместе самостоятельно решать задачи, обсуждать решение. Для этого я использую образовательную платформу ЯКласс. В это время я продолжаю объяснять учебный материал другим ученикам, контролирую закрепление темы. Затем я работаю с сильной группой, консультирую, корректирую их ошибки. Благодаря дифференцированному подходу способные ученики углубленно изучают тему, решают нестандартные и развивающие задачи на платформе ЯКласс, в разделе Переменка. Такие задания можно предлагать, как дополнительные (т. е. не обязательные для выполнения) всему классу, но для одарённых учащихся эти задания являются обязательными. Дети не должны бояться делать ошибки (ведь на ошибках учатся), и не ошибается тот, кто ничего не делает. Поэтому за дополнительные задания ставится лишь положительная оценка при условии, что выполнено без ошибок. В противном случае отметка не обязательна. Это приводит к тому, что ученики с желанием пробуют свои силы, экспериментируют, им интересно решать. Для развития способностей у учащихся необходимо предлагать различные типы олимпиадных задач:

- логические задачи;

- математические ребусы;

- инварианты;

- принцип Дирихле;

- геометрические задачи (на разрезание и др.);

- арифметические задачи, текстовые задачи.

Дополнительные возможности для индивидуальной работы предоставляет использование информационных технологий на уроке и во внеурочное время. Использование готовых цифровых ресурсов в сети Интернет позволяет учащимся выполнять задания различного уровня сложности, включая развивающие, исследовательские.

Ученики нашей школы уже давно работают на образовательной платформе ЯКласс. Наша школа занимает 3-4 места в топе школ по городу Чебоксары. Ребята с интересом соревнуются между классами.

Чем же нам, учителям школы, нравится эта платформ?

Во-первых, каждому ребенку дается свое индивидуальное задание, т. е. меньше шансов списать, происходит объективная оценка знаний.

Во-вторых, можно самому педагогу составить свою проверочную работу.

В-третьих, при подключении ЯКласс плюс, система сама объясняет ошибки ученику, дает возможность выполнить работу над ошибками. 
В-четвертых, нет проблемы с оценками. Если даже учитель уходит на больничный или другая причина отсутствия, можно дать ребятам задание в ЯКлассе и поставить оценки в журнал.

Благодаря данной платформе можно во главу угла ставить задачу развития самодеятельности учащихся. Естественно, происходит отказ от авторитарного стиля общения в пользу демократического. Я работаю над созданием такой модели системы обучения учащихся, которая позволила бы учащимся повысить мотивацию к обучению математике, создать условия для развития математических способностей детей, приобрести специальные учебные навыки с учетом индивидуальных желаний и способностей. Обучение организовано так, чтобы целенаправленно вести за собой развитие. Ученик, получая знания не в готовом виде, а, добывая их сам на основе цифровых технологий, осознает при этом содержание и формы своей учебной деятельности, понимает и принимает систему ее норм, активно участвует в их совершенствовании.

Применение образовательных платформ на уроках осуществляется через:

- моделирование и анализ жизненных ситуаций на занятиях;

- использование активных и интерактивных методик;

- участие в проектной деятельности, владение приёмами исследовательской деятельности;

- вовлечение учащихся в игровую, оценочно-дискуссионную, рефлексивную деятельность, а также проектную деятельность - обеспечивающих свободный поиск эффективного, отвечающего индивидуальности ребёнка, подхода к решению задачи.

Учащиеся:

- работают с источниками информации, с современными средствами коммуникации;

- решают познавательные и практические задачи, отражающие типичные ситуации;

- аргументируют защиту своей позиции;

- выполняют творческие работы и исследовательские проекты.

На этапе самоопределения к учебной деятельности и актуализации знаний создается проблемная ситуация, которая предполагает наличие разных вариантов решения проблем.

Очень важно ставить перед учащимися задания, требующие самостоятельного их поиска или создания, подбирать задачи, содержательная сторона которых соответствует реальной действительности. По возможности использовать для них материал, отвечающий интересам учеников. При этом надо учить их при решении задачи переходить на абстрагированный уровень, отвлекаясь от конкретного содержания.

В обучении математике главная цель задач - развивать математический стиль мышления учащихся, заинтересованность их математической деятельностью. Важно направить одаренного ребенка не на получение определенного объема знаний, а на творческую его переработку, воспитать способность мыслить самостоятельно, на основе полученного материала.

\section{Список литературы}

1. Петерсон Л.Г. Требования к составлению плана урока по дидактической системе деятельностного метода / Л.Г. Петерсон, М.А. Кубышев, Т.Г. Кудряшова. - М.: УМЦ «Школа $2000 \ldots ., 2005$.

2. Шуба М.Ю. Учимся творчески мыслить на уроках математики. Пособие для учителей. - М.: Просвещение, 2012. 
Волкова Светлана Николаевна

д-р с.-х. наук, профессор

Сивак Елена Евгеньевна д-р с.-х. наук, профессор

ФГБОУ ВО «Курская государственная сельскохозяйственная академия им. И.И. Иванова»

г. Курск, Курская область

\section{ПРИМЕНЕНИЕ МЕТОДА НАИМЕНЫШИХ КВАДРАТОВ К ПОДБОРУ ПРОИЗВОДСТВЕННЫХ ФУНКЦИЙ}

Аннотация: в статье представлены методы обработки экспериментальных данных, применяемые при заполнении лабораторных, расчетнографических, контрольных работ, в научно-исследовательской работе, при курсовом и дипломном проектировании на различных факультетах, поскольку методь позволяют исследовать закономерности моделей независимо от их конкретной природы.

Ключевые слова: производственные функции, метод наименьиих квадратов, формуль, экспериментальные данные, параметры, уравнения.

За всю многовековую историю математика не была унитарной наукой. Математика - это язык, это ключ к познанию диалектического понимания природы. «Это большой город, чьи предместья не перестают разрастаться несколько хаотическим образом на окружающем его пространстве, в то время как центр периодически перестраивается, следуя каждый раз все более и более ясному плану и стремясь к все более и более величественному расположению, в то время как старые кварталы с их лабиринтами переулков сносятся для того, чтобы проложить к окраинам улицы все более прямые, все более широкие, все более удобные». В подтверждение тому теория вероятностей - математическая наука о количественных закономерностях моделей случайных явлений независимо от их конкретной природы и математическая статистика, занимающаяся разработкой методов сбора, регистрации и обработки результатов наблюдений с целью познания закономерностей случайных массовых явлений.

Методы обработки экспериментальных данных, изложенные в статье, следует применять при заполнении лабораторных, расчетно-графических, контрольных работах; в научно-исследовательской работе, при курсовом и дипломном проектировании на различных факультетах, поскольку методы позволяют исследовать закономерности моделей независимо от их конкретной природы [1, с. 35].

Подбор производственных функций и определение их параметров методом наименьших квадратов: Требуется составить уравнение динамики роста урожайности по ниже приведенным данным, характеризующим динамику роста урожайности зерновых культур (табл. 1), овощей (табл. 2), сеянных трав (табл. 3), кукурузы, плодов (табл. 4.) в учхозе СХА по годам в зависимости от удобрения (табл. 5). 
Цели работы:

1) освоить метод наименьших квадратов;

2) ознакомиться с методикой решения подбора эмпирических формул на компьютере;

3) составить уравнение по указанным данным [2, с. 78].

При выполнении работы за Х принимают одну из колонок таблицы 5 , соответствующую порядковому номеру студента в журнале $\mathrm{n}$ и номер группы N. За Y принимают столбец, соответствующий порядковому номеру студента в журнале из таблиц $1-4$.

Например, пусть студент из первой группы $(\mathrm{N}=1)$ и его порядковый номер в журнале $9(\mathrm{n}=9)$. Тогда он выбирает 1-ый столбец из табл. 5. соответствующей $\mathrm{n}=9$ с наименованием с наименованием «Год» и столбец под номером 9 из табл. 1 «Озимые» и получает таблицу 6.

Таблица 1

Урожайность зерновых (ц/га)

\begin{tabular}{|c|c|c|c|c|c|c|c|c|}
\hline 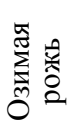 & 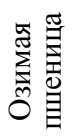 & 惥 & $\begin{array}{l}\text { ठ } \\
\text { Oొ }\end{array}$ & $\stackrel{\widetilde{\Xi}}{\stackrel{\varpi}{\leftrightarrows}}$ & 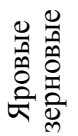 & 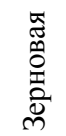 & 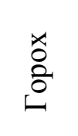 & 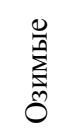 \\
\hline 1 & 2 & 3 & 4 & 5 & 6 & 7 & 8 & 9 \\
\hline 17,9 & 21,2 & 11,9 & 31,2 & 13,9 & 13,3 & 17,6 & 11,4 & 21 \\
\hline 30,1 & 27,4 & 13,5 & 30,6 & 25,4 & 19,4 & 22,3 & 8,2 & 27,7 \\
\hline 34,5 & 27,2 & 30,9 & 37,5 & 25,5 & 30,0 & 28,8 & 22,2 & 27,9 \\
\hline 33,9 & 27,7 & 32 & 26,3 & 24,4 & 29 & 29 & 18,7 & 28,7 \\
\hline 28,3 & 25,7 & 32,9 & 25,2 & 18,5 & 28,1 & 27 & 12,6 & 26 \\
\hline 28,6 & 31,6 & 38,8 & 30,2 & 21,5 & 33,2 & 32,2 & 14,6 & 31 \\
\hline 39,1 & 43,3 & 41,1 & 26,6 & 18,6 & 38 & 40,4 & - & 42,6 \\
\hline
\end{tabular}

Таблица 2

Урожайность овощей

\begin{tabular}{|c|c|c|c|c|c|}
\hline Картофель & Овощи & Огурцы & Помидоры & Капуста & $\begin{array}{c}\text { Кормовая } \\
\text { свекла }\end{array}$ \\
\hline 10 & 11 & 12 & 13 & 14 & 15 \\
\hline 90,6 & 90 & 106 & 57 & - & 340 \\
\hline 108 & 495 & 185 & 15 & 719 & 428 \\
\hline 155,4 & 245,8 & 190 & 130 & 422,7 & 326,1 \\
\hline 157,2 & 456,7 & 114 & 9 & 756,7 & 636,7 \\
\hline 117,5 & 387,1 & 50 & 27,5 & 660,1 & 570 \\
\hline 223,8 & 160,6 & 121 & 141 & 252,2 & 605,6 \\
\hline 179 & 120,6 & 45 & 239 & 130,7 & 399 \\
\hline
\end{tabular}


Урожайность сеянных трав

\begin{tabular}{|c|c|c|c|c|c|c|}
\hline 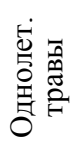 & $\begin{array}{l}\frac{\pi}{2} \\
\frac{0}{0} \\
\frac{3}{m}\end{array}$ & 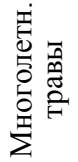 & 营 & 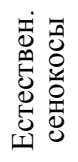 & $\begin{array}{l}\text { 官 } \\
\text { 总 } \\
\text { 总 }\end{array}$ & $\begin{array}{l}\frac{\pi}{2} \\
\frac{0}{0} \\
\frac{z}{m}\end{array}$ \\
\hline 16 & 17 & 18 & 19 & 20 & 21 & 22 \\
\hline 41,1 & 68,1 & 30,1 & 203,7 & 31,5 & 40 & 180 \\
\hline 49,7 & 145 & 53,1 & 317 & 34,6 & 41 & 185 \\
\hline 43,7 & 83,4 & $\begin{array}{l}50,9 \\
\end{array}$ & 640,8 & 31 & 41,1 & 190 \\
\hline 44,2 & 145,5 & 46 & 331,8 & 17 & 42 & 195 \\
\hline 46,4 & 104,7 & 54,3 & 306 & 17,2 & 43 & 191,7 \\
\hline 35,8 & 149,3 & 51,8 & 205,8 & 32 & 45 & 181,7 \\
\hline 59,4 & 157,6 & 58,2 & 440,2 & 31,3 & 47 & 182 \\
\hline
\end{tabular}

Таблица 4

Урожайность плодов и кукурузы

\begin{tabular}{|c|c|c|}
\hline Плоды & Кукуруза 1 & Кукуруза \\
\hline 23 & 24 & 25 \\
\hline 82,1 & 167,7 & 290 \\
\hline 58,9 & 115 & 300 \\
\hline 36,3 & 438,7 & 310 \\
\hline 67,4 & 392,9 & 301 \\
\hline 60,2 & 242 & 305 \\
\hline 58,2 & 430 & 295 \\
\hline 24,4 & 473 & 315 \\
\hline
\end{tabular}


Таблица 5

Урожайность по годам (кг/га)

\begin{tabular}{|c|c|c|c|c|c|c|c|c|c|}
\hline \multirow{2}{*}{ Год } & \multicolumn{4}{|c|}{$\begin{array}{c}\text { Удобрения } \\
\mathrm{n}=1,2,3,4,5,6,7,8,9\end{array}$} & Год & \multicolumn{4}{|c|}{ Удобрения $\mathrm{n}=23$} \\
\hline & $\mathrm{N}$ & $\mathrm{P}$ & $\mathrm{K}$ & Всего & & $\mathrm{N}$ & $\mathrm{P}$ & $\mathrm{K}$ & Всего \\
\hline 1 & 2 & 3 & 4 & 5 & 1 & 2 & 3 & 4 & 5 \\
\hline 2010 & 98 & 41 & 53 & 173 & 1981 & 120 & 7 & 38 & 166 \\
\hline 2011 & 74 & 53 & 114 & 242 & 1982 & 148 & 36 & 48 & 234 \\
\hline 2012 & 75 & 48 & 63 & 186 & 1983 & 98 & 45 & 112 & 255 \\
\hline 2013 & 128 & 85 & 157 & 371 & 1984 & 165 & 52 & 168 & 355 \\
\hline 2014 & 155 & 81 & 114 & 350 & 1985 & 107 & 37 & 50 & 195 \\
\hline 2015 & 150 & 113 & 115 & 378 & 1986 & 118 & 90 & 45 & 253 \\
\hline 2016 & 231 & 101 & 143 & 475 & 1987 & 166 & 111 & 127 & 404 \\
\hline \multicolumn{5}{|c|}{$\mathrm{n}=10,11,12,13,14$} & \multicolumn{5}{|c|}{$\mathrm{n}=24,25$} \\
\hline 1 & 225 & 175 & 178 & 578 & 1 & 100 & 54 & 63 & 218 \\
\hline 2 & 280 & 106 & 213 & 600 & 2 & 165 & 56 & 92 & 313 \\
\hline 3 & 233 & 120 & 190 & 543 & 3 & 168 & 65 & 187 & 421 \\
\hline 4 & 213 & 159 & 234 & 606 & 4 & 304 & 35 & 177 & 517 \\
\hline 5 & 139 & 107 & 150 & 396 & 5 & 195 & 70 & 105 & 370 \\
\hline 6 & 135 & 203 & 203 & 541 & 6 & 410 & 318 & 296 & 1024 \\
\hline 7 & 120 & 124 & 168 & 412 & 7 & 248 & 162 & 92 & 502 \\
\hline \multicolumn{10}{|c|}{$\mathrm{n}=15$} \\
\hline 1 & & & 53 & & 123 & & 133 & & 410 \\
\hline 2 & & & 80 & & 106 & & 213 & & 600 \\
\hline 3 & & & 33 & & 120 & & 190 & & 543 \\
\hline 4 & & & 30 & & 85 & & 223 & & 562 \\
\hline 5 & & & 53 & & 276 & & 380 & & 1010 \\
\hline 6 & & & 04 & & 70 & & 70 & & 344 \\
\hline 7 & & & 70 & & 206 & & 170 & & 746 \\
\hline \multicolumn{10}{|c|}{$\mathrm{n}=16,17,18,19,20,21,22$} \\
\hline 1 & & & 92 & & 23 & & 6 & & 122 \\
\hline 2 & & & 05 & & 29 & & 32 & & 166 \\
\hline 3 & & & 04 & & 25 & & 9 & & 138 \\
\hline 4 & & & 43 & & 80 & & 128 & & 351 \\
\hline 5 & & & 44 & & 42 & & 57 & & 244 \\
\hline 6 & & & 28 & & 28 & & 36 & & 292 \\
\hline 7 & & & 55 & & 100 & & 71 & & 326 \\
\hline
\end{tabular}

Таблица 6

Экспериментальные данные

\begin{tabular}{|l|l|l|l|l|l|l|l|}
\hline $\mathrm{X}$ & 2010 & 2011 & 2012 & 2013 & 2014 & 2015 & 2016 \\
\hline $\mathrm{Y}$ & 21 & 27,7 & 27,9 & 28,7 & 26 & 31 & 42,6 \\
\hline
\end{tabular}

Можно упростить и вместо 2010 ввести - 1, 2011 - 2 и т. д. Таким образом, заменив год на цифры 1, 2, 3, 4, 5, 6, 7, получим таблицу 7. 
Экспериментальные данные

\begin{tabular}{|l|l|l|l|l|l|l|l|}
\hline $\mathrm{X}$ & 1 & 2 & 3 & 4 & 5 & 6 & 7 \\
\hline $\mathrm{Y}$ & 21 & 27,7 & 27,9 & 28,7 & 26 & 31 & 42,6 \\
\hline
\end{tabular}

Зависимость У от $\mathrm{X}$ находят в виде $y=a x+\varepsilon$ (линейная), или $y=a x^{2}+b x+c$ (квадратичная), или другой, используя метод наименьших квадратов при определении параметров а, в, с.

Рассмотрим теперь более сложный случай [3, с.10]. Пусть предполагается, что зависимость признака $\mathrm{Y}$ от признака $\mathrm{X}$ имеет вид $y=f\left(x, \alpha_{1}, \alpha_{2}, \ldots \alpha_{m}\right)$, где $\mathrm{x}$ - значения признака $\mathrm{X}, \mathrm{y}$ - значения признака Y; $\alpha_{1}, \alpha_{2}, \ldots, \alpha_{m}$ подлежащие определению параметры, и что в результате эксперимента были получены следующие эмпирические данные таблицы 8.

Таблица 8

Эмпирические данные

\begin{tabular}{|l|l|l|l|l|l|l|}
\hline Значение признака X & $x_{1}$ & $x_{2}$ & $\cdots$ & $x_{i}$ & $\cdots$ & $x_{n}$ \\
\hline Значение признака Y & $y_{1}$ & $y_{2}$ & $\cdots$ & $y_{i}$ & $\cdots$ & $y_{n}$ \\
\hline
\end{tabular}

Метод наименьших квадратов (МНК) утверждает, что наивероятнейшие значения параметров $\alpha_{1}, \alpha_{2}, \ldots, \alpha_{m}$ дает минимум функции

$$
S=\sum_{n=1}^{n}\left(y_{i}-f\left(x_{i}, \alpha_{1}, \alpha_{2}, \ldots \alpha_{m}\right)\right)^{2}
$$

Если $f\left(x, \alpha_{1}, \alpha_{2}, \ldots \alpha_{m}\right)$ имеет непрерывные частные производные по всем своим параметрам, то необходимым условием минимума функции представляет систему $\mathrm{m}$ уравнений с $\mathrm{m}$ - неизвестными:

$$
\frac{\partial S}{\partial \alpha_{1}}=0 ; \frac{\partial S}{\partial \alpha_{1}}=0 ; \ldots \frac{\partial S}{\partial \alpha_{m}}=0
$$

Нахождение функциональной зависимости между признаками $\mathrm{Y}$ и $\mathrm{X}$ на основании (1) называют выравниванием эмпирических данных вдоль кривой $y=f\left(x, \alpha_{1}, \alpha_{2}, \ldots, \alpha_{m}\right)$.

Если $f\left(x, \alpha_{1}, \alpha_{2}, \ldots, \alpha_{m}\right)=\alpha_{1} x+\alpha_{2}$, то этой кривой будет прямая линия $y=\alpha_{1} x+\alpha_{2}$. В этом случае система (2) может быть преобразована в так называемую нормальную систему МНК при выравнивании по прямой: 


$$
\begin{gathered}
\alpha_{1} \sum_{i=1}^{n} x_{i}^{2}+\alpha_{2} \sum_{1}^{n} x_{i}=\sum_{1}^{n} x_{i} y \\
\alpha_{1} \sum_{i=1}^{n} x_{i}+\alpha_{2} n=\sum_{1}^{n} y_{i}
\end{gathered}
$$

Система (2) при выравнивании по параболе $y=\alpha_{1} x^{2}+\alpha_{2} x+\alpha_{3}$ может быть преобразована к виду:

$$
\left\{\begin{array}{l}
\alpha_{1} \sum_{i=1}^{n} x_{i}^{4}+\alpha_{2} \sum_{1}^{n} x_{i}^{3}+\alpha_{3} \sum_{1}^{n} x_{i}^{2}=\sum_{1}^{n} x_{i}^{2} y_{i} \\
\alpha_{1} \sum_{i=1}^{n} x_{i}^{3}+\alpha_{2} \sum_{1}^{n} x_{i}^{2}+\alpha_{3} \sum_{1}^{n} x_{i}=\sum_{1}^{n} x_{i} y_{i} \\
\alpha_{1} \sum_{1}^{n} x_{i}^{2}+\alpha_{2} \sum_{1}^{n} x_{i}+\alpha_{3} n=\sum_{1}^{n} y_{i}
\end{array}\right.
$$

Пусть в результате эксперимента получена таблица 9.

Таблица 9

Вспомогательная таблица

\begin{tabular}{|c|c|c|c|c|c|c|c|}
\hline$x_{i}$ & 23 & 29 & 25 & 80 & 42 & 28 & 100 \\
\hline$y_{i}$ & 40 & 41 & 41,1 & 42 & 43 & 45 & 47 \\
\hline
\end{tabular}

Здесь $y_{i}$ - урожайность однолетних трав в учхозе СХА; $x_{i}$-количество внесенных удобрений.

Построим на плоскости точки с соответствующими координатами (23; $40) ;(29 ; 41)$...; $(100 ; 47)$ рисунок 1 . Плавно соединим точки [4, с.79]. Точки с координатами $(80 ; 42)$ и $(28 ; 450$ удалены от предполагаемой линии. Поэтому при подборе зависимости $y=a x+b$, эти значения исключим из рассмотрения. По оставшимся пяти значениям подберем формулу и найдем параметры а и b методом наименьших квадратов.

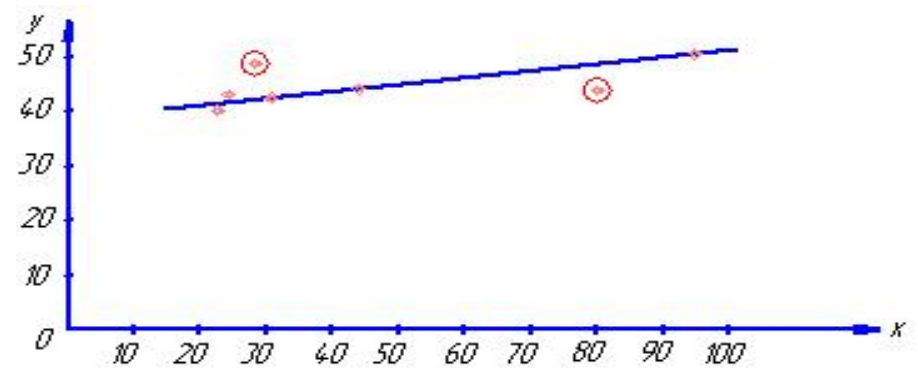

Рис. 1. Графическое изображение эмпирических данных 
Так как выравниваются эмпирические данные вдоль прямой, то пользуемся системой (3) [5, с. 32]. Результаты вычислений удобно вести с помощью таблицы 10.

Схема расчета параметров а и $\mathrm{b}$ МНК

\begin{tabular}{|l|l|l|l|l|l|l|l|}
\hline $\mathrm{N}$ & $x_{i}$ & $y_{i}$ & $x_{i} y_{i}$ & $x_{i}^{2}$ & $y_{i}=a x_{i}+b$ & $\varepsilon_{i}=Y_{i}-y_{i}$ & $\varepsilon_{i}^{2}$ \\
\hline 1 & 23 & 40 & 920 & 529 & 40,6598 & 0,6598 & 0,43534 \\
2 & 25 & 41,1 & 1027, & 625 & 40,892 & $-0,274$ & 0,07576 \\
3 & 29 & 41 & 5 & 841 & 41,1674 & 0,1679 & 0,02819 \\
4 & 42 & 43 & 1189 & 1764 & 42,2672 & $-0,7328$ & 0,536996 \\
5 & 10 & 47 & 1806 & 1000 & 47,714 & 0,174 & 0,030276 \\
& 0 & & 4700 & 0 & & & \\
\hline$\sum$ & 21 & 212, & 9642, & 1375 & - & - & 1,105874 \\
\hline
\end{tabular}

В систему (3) для $\mathrm{n}=5$, имеющую вид:

$$
\left\{\begin{array}{l}
a \sum_{1}^{5} x_{i}^{2}+b \sum_{1}^{5} x_{i}=\sum_{1}^{5} x_{i} y_{i} \\
a \sum_{1}^{5} x_{i}+5 b=\sum_{1}^{5} y_{i}
\end{array}\right.
$$

подставляем данные из табл. 3.6., получаем:

$$
\left\{\begin{array}{l}
13759 a+219 b=9642,5 \\
219 a+5 b=212,1
\end{array}\right.
$$

Решаем систему (5), находим $\mathrm{a}=0,084602 ; \mathrm{b}=38,714428$.

Уравнение динамики роста урожайности (производственная функция) имеет вид: $\mathrm{y}=0,084602 \mathrm{x}+38,714428(6)$.

Оценим погрешность полученного результата и заполним соответствующие столбцы в таблице 9. Для этого по формуле (31) для каждого $x_{i}$ находим $y_{i}$. Затем вычисляем $\varepsilon_{i}=Y_{i}-y_{i}$, и находим $\varepsilon_{i}^{2}$. Таким образом, параметры а и b в уравнении (6), рассчитанные МНК, получены с точностью 1,1 .

Рассмотрим пример криволинейной корреляции. Пусть в результате эксперимента получена таблица 11.

Таблица 11

Урожайность (ц/га) озимой пшеницы по годам

\begin{tabular}{|l|l|l|l|l|l|l|l|}
\hline $\mathrm{x}$ & 2010 & 2011 & 2012 & 2013 & 2014 & 2015 & 2016 \\
\hline $\mathrm{y}$ & 31,9 & 27,4 & 27,2 & 27,7 & 25,7 & 31,6 & 43,3 \\
\hline
\end{tabular}


Построим на координатной плоскости точки с координатами $\left(x_{i}, y_{i}\right)$. В дальнейшем года заменим на цифры 1, 2, 3, 4, 5, 6, 7, что не повлияет на результат исследования.

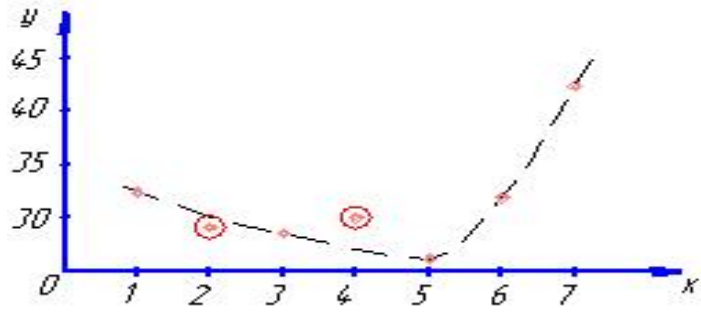

Рис. 2. Эмпирические данные и линия регрессии

Плавно соединив эмпирические данные линией, будем выравнивать по параболе $\mathrm{y}=\mathrm{ax}+\mathrm{BX}+\mathrm{c}$, исключив из рассмотрения точки, соответствующие 2011 и 2014 гг. Параметры а, в, и с определим МНК по формуле (3), имеющий вид для $\mathrm{n}=5$ :

$$
\left\{\begin{array}{l}
a \sum_{1}^{5} x_{i}^{4}+b \sum_{1}^{5} x_{i}^{3}+c \sum_{1}^{5} x_{i}^{2}=\sum_{1}^{5} x_{i}^{2} y_{i} \\
a \sum_{1}^{5} x_{i}^{3}+b \sum_{1}^{3} x_{i}^{2}+c \sum_{1}^{5} x_{i}=\sum_{1}^{5} x_{i} y_{i} \\
a \sum_{1}^{5} x_{i}^{2}+b \sum_{1}^{5} x_{i}+5 c=\sum_{1}^{5} y_{i}
\end{array}\right.
$$

Расчеты проведем в таблице 12.

Таблица 12

Схема расчетов параметров а, в и с МНК

\begin{tabular}{|c|c|c|c|c|c|c|c|c|c|c|}
\hline$\Pi / \Pi$ & $x_{i}$ & $y_{i}$ & $x_{i}^{4}$ & $x_{i}^{3}$ & $x_{i}^{2}$ & $x_{i}^{2} y_{i}$ & $x_{i} y_{i}$ & $y_{i}=a x_{i}^{2}+b x_{i}+c$ & $b_{i}$ & $\varepsilon_{i}^{2}$ \\
\hline 1 & 2 & 3 & 4 & 5 & 6 & 7 & 8 & 9 & 10 & 11 \\
\hline 1 & 1 & 319 & 1 & 1 & 1 & 31,9 & 31,9 & 33,2 & 1,3 & 1,69 \\
2 & 2 & 272 & 16 & 8 & 4 & 108,3 & 54,4 & 25,97 & -123 & 1,51 \\
3 & 3 & 257 & 81 & 27 & 9 & 231,3 & 77,1 & 25,24 & $-0,46$ & 0,21 \\
4 & 4 & 316 & 256 & 64 & 16 & 505,6 & 126,4 & 31,31 & $-0,29$ & 0,08 \\
5 & 5 & 433 & 625 & 125 & 25 & 1082,5 & 216,5 & 44,08 & 0,78 & 0,6 \\
\hline$\Sigma$ & 15 & 159,7 & 977 & 225 & 55 & 1960,1 & 506,3 & 159,8 & - & 4,09 \\
\hline
\end{tabular}


Подставляя в формулу данные из таблицы, получим:

$$
\left\{\begin{array}{l}
977 a+225 b+55 c=1960,1 \\
225 a+55 b+15 c=506,3 \\
55 a+15 b+5 c=159,7
\end{array}\right.
$$

Решая, находим а $=3,35 ; \mathrm{в}=-17,38 ; \mathrm{c}=47,23$.

Динамика роста урожайности озимой пшеницы по годам описывается производственной функцией

$$
y=3,35 x^{2}-17,38 x+47,23
$$

Оценим погрешность полученного результата. Для этого найдем для каждого $x_{i}$ значения $y_{i}$ по формуле (9), затем вычислим разность между теоретическим значением $Y_{i}$ и эмпирическим $y_{i}$, т.е. $\varepsilon_{i}=Y_{i}-y_{i}$ и найдем $\varepsilon_{i}^{2}$, заполнив соответствующие столбцы 9, 10, 11 в табл. 3.3.4. В результате проведенного исследования делаем вывод, что параметры а, в и с в формуле определены МНК) [6, с. 12].

Следует отметить, что рассмотренные в примерах математические модели-упрощенные, о чем свидетельствует и полученная погрешность. Но даже на этих моделях можно сделать прогноз на ближайшую перспективу, варьируя переменные величины в рамках модели.

Выполнять данную работу следует с применением вычислительной техники разного уровня от микрокалькуляторов до ППЭВМ с привлечением к расчетам пакета прикладных программ, т. е. от частичного автоматизирования до полной автоматизации процесса.

На практике, работая со студентами дневного отделения, есть студенты, которые по заданному алгоритму сами составляют программы и автоматизируют всю лабораторную работу. Но интерпретацию результатов все равно им приходилось делать самостоятельно, получив модель компьютерного варианта. В случае разницы просчитанных работ с помощью калькулятора и с помощью ППЭВМ при защите работ ребятам надо было это объяснить результаты. Это активизировало их к более глубокому изучению самих цифр, точности их расчетов, заложенных в программный продукт.

Считаем, что такие работы полезны и для школьников в их научных исследованиях, а не только в вузе. Поскольку, нет ничего увлекательнее, выравнивать экспериментальные данные к любой линии, в том числе и кусочно-заданной на некоторых промежутках. А получив аналитическую модель, обучающийся превращается в руководителя того процесса, который изучает. Поскольку может получать не только интересующие его значения на построенном отрезке, но и знать изменения результата при изменении фактора, а следовательно строить краткосрочный прогноз при стабильной ситуации развития изучаемого процесса) [7, с. 21].

Возможен коллективный проект, когда весь класс или группа принимает участие и делает общий вывод по результатам исследования, а именно какую культуру для выращивания можно рекомендовать в рассмотренных условиях, для какой необходимо дополнительное исследование по объему выборки, а какую следует повременить с рекомендацией к производству. 
Работая с цифрой и ее точностью, в случае обработки эксперимента, прививается навык исследовательской деятельности и творческого поиска в решении поставленной задачи.

\section{Список литературы}

1. Волкова С.Н. К вопросу оценки качества прогнозов моделирования экосистем / С.Н. Волкова, Т.И. Романова, М.И. Пашкова [и др.] // Вестник Курской государственной сельскохозяйственной академии. - 2017. - №3. - С. 38-44.

2. Волкова С.Н. Нелинейные взаимодействия и их моделирование в социально-экологических системах / С.Н. Волкова, Е.Е. Сивак, М.И. Пашкова [и др.] // Вестник Курской государственной сельскохозяйственной академии. - 2016. - №3. - С. 77-80.

3. Сивак Е.Е. Новые нетрадиционные культуры - перспектива развития сельского хозяйства // Аграрная наука. - 2006. - №7. - С. 9-10.

4. Волкова С.Н. Последствия антропогенного воздействия в развитии сельского хозяйства / С.Н. Волкова, Ю.И. Майоров, Е.Е. Сивак [и др.] // Вестник Курской государственной сельскохозяйственной академии. - 2012. - №2. - С. 78-80.

5. Шлеенко А.В. Прогнозирование рисков, разрушающих естественные экосистемы / А.В. Шлеенко, С.Н. Волкова, Е.Е. Сивак [и др.] // Известия Юго-Западного государственного университета. - 2014. - №1 (52). - С. 30-34.

6. Волкова С.Н. Разработка технологии биоэнергетики / С.Н. Волкова, Е.Е. Сивак, В.В. Морозова [и др.] // Известия Юго-Западного государственного университета. Серия: Техника и технологии. - 2017. - Т. 2. - С. 11-14.

7. Волкова С.Н. Улучшение структуры землепользования / / С.Н. Волкова, Е.Е. Сивак, В.В. Морозова [и др.] //Вестник Курской государственной сельскохозяйственной академии. - 2017. - №1. - С. 20-24.

Глебова Мария Владимировна канд. физ.-мат. наук, доцент

Педагогический институт им. В.Г. Белинского ФГБОУ ВО «Пензенский государственный университет» г. Пенза, Пензенская область

\section{ТРЕБОВАНИЯ К ПРОВЕДЕНИЮ ДИСТАНЦИОННОГО ТЕСТИРОВАНИЯ ПО МАТЕМАТИКЕ В ЦИФРОВОЙ ОБРАЗОВАТЕЛЬНОЙ СРЕДЕ}

Аннотация: в статье предложень рекомендации по подготовке и проведению дистанционного тестирования по высшей математике у студентов нематематического профиля. Выяснено, есть ли возможность провести качественное дистанционное тестирование с помощью интернет-программ для создания тестов.

Ключевые слова: дистанционное обучение, дистаниионное тестирование, оценка знаний, оценка умений, оценка навыков.

Изменения, происходящие в настоящее время в обществе, находят свое отражение и в образовании. Сегодня, как никогда, остро стоит проблема качества дистанционного обучения и дистанционной оценки полученных знаний. «Дистанционное обучение - это взаимодействие преподавателей и студентов на расстоянии, отражающее все компоненты, присущие образовательному процессу и реализуемые конкретными средствами интернет-технологий или иными средствами, обеспечивающими

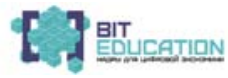


интерактивность» [2], ведущим инструментом этого обучения являются информационные технологии.

Как и при обычном, так и при дистанционном обучении также остается важным своевременное обнаружение недостаточного понимания изучаемого понятия или некоторых операций формируемого навыка. Существенную помощь в этом оказывают тестовые технологии. «Использование тестов является одним из рациональных дополнений к методам проверки знаний, умений и навыков учащихся на разных уровнях образования» [3].

Тестирование сразу всей группы студентов имеет ряд значительных преимуществ перед иными видами существующего контроля. Тестирование позволяет быстро диагностировать учебный материал большему числу студентов. Вместе с тем строгий порядок проверки знаний студентов почти исключает субъективизм. Регулярное использование тестирования студентов формирует у них дисциплинированность и стремление к соревновательности в освоении учебного материала.

В контексте дистанционного обучения тестирование студентов приобрело ряд особенностей, которые мы рассмотрим в данной статье.

Если при аудиторном тестировании преподаватель имел возможность лично присутствовать на тестировании и полностью контролировать процесс тестирования, тем самым имея возможность получить объективный результат обучения, то при дистанционном тестировании нет полного контроля над процессом ответов учащихся, нет абсолютной уверенности в том, что ученику не подсказали ответ или он не нашел его в Интернете. Чтобы свести к минимуму эту возможность, мы рекомендуем следующее.

Во-первых, ограничьте время ответа на каждый вопрос, если есть такая опция в программе создания теста,

Во-вторых, сформулируйте задачу в неклассической форме.

Например, распространенную формулировку «найти произведение матриц $\left(\begin{array}{ll}0 & 3 \\ 1 & 2\end{array}\right) \cdot\left(\begin{array}{ccc}4 & 2 & -1 \\ 3 & 1 & 0\end{array}\right) »$ заменить на формулировку «выберите вариант ответа, поясняющий вычисление элемента -1 в матрице $C=\left(\begin{array}{ll}0 & 3 \\ 1 & 2\end{array}\right) \cdot\left(\begin{array}{ccc}4 & 2 & -1 \\ 3 & 1 & 0\end{array}\right)=\left(\begin{array}{ccc}9 & 3 & 0 \\ 10 & 4 & -1\end{array}\right)$

Варианты ответа: а) $2 \cdot 1-3 \cdot 1$, б) $0 \cdot 0+1 \cdot(-1)$, в) $1 \cdot(-1)+2 \cdot 0$, г) $2 \cdot 4-3 \cdot 3$ » и т. п. Ответ на данный вопрос не требует много времени на размышление так как не требует большого числа вычислений, но при этом проверяет усвоил ли студент суть операции умножения матриц.

Или, например, распространенную формулировку «выберите уравнение эллипса» или «выберите уравнение гиперболы», заменить на «чем отличаются простейшее уравнение эллипса от простейшего уравнения гиперболы?»

Варианты ответа: а) знаком у коэффициента перед переменной $y$; б) знаком у коэффициента перед переменной $x$; в) свободным коэффициентом; г) степенью переменных.

В-третьих, ограничьте возврат к предыдущим вопросам. Это исключает возможность фотографирования задачи и поиска ее решения в Интернете из-за ограниченного времени отклика.

Для того чтобы такое тестирование не приносило большого стресса для студентов, необходимо провести с ними подготовительную работу: объяснить все организационные детали этого тестирования. 
Выясним, можно ли реализовать рекомендации, приведенные выше с помощью программ создания тестов, доступных в Интернете. Ниже приведен обзор некоторых программ для создания тестов.

Обратим внимание на следующие факты:

- свободная доступность,

- возможность задавать формулы и вставлять изображения,

- возможность регулировать время ответов на каждый вопрос,

- возможность варьировать баллы за ответы,

- возможность просматривать правильные ответы после завершения тестов.

Рассмотрим некоторые программы, доступные в Интернете для создания тестов. Рассмотрим приложение Quizizz. Его можно установить, как на компьютеры, так и на мобильные телефоны. Данное приложение бесплатное. Он имеет отдельный режим «ученик» и режим «учитель». В режиме учителя можно создавать тесты. Вы можете установить определенный лимит времени для каждой задачи. Продолжительность выполнения каждого задания определяется преподавателем в зависимости от сложности поставленной задачи. Тесты делаются либо с одним вариантом ответа, либо с несколькими, либо предлагаются задания открытого типа. Это приложение не использует задание на соответствие. Quizizz содержит интересный интерфейс. Студент, который выполняет задания, может увидеть, правильно ли он ответил на вопрос или нет, и может исправить ошибку.

Программа MyTestX является одной из наиболее широко используемых программ в нашей стране для создания тестов. Данное приложение бесплатное. Программа проста и удобна в использовании. Все студенты учатся этому быстро и легко. Каждый учитель, даже тот, у кого есть компьютер на начальном уровне, может легко создать свои собственные тесты с помощью программы MyTest. Результаты выполнения заданий выводятся тестирующему и отправляются преподавателю.

Эта программа работает с несколькими типами вариантов ответа: один или несколько; установка порядка следования, согласования, ручной ввод ответа, выбор места на изображении. Можно установить оптимальное время тестирования, установленное преподавателем. Также можно настраивать время ответа на каждое любого задание. Преподавателю очень удобно, что условия задания, параметры теста и чертежи заданий хранятся в одном файле для этого теста. Статистика для преподавателя очень хорошо представлена: преподаватель может видеть количество запусков программы, процент правильных ответов и время, проведенное в программе ученика.

Программа Kahoot - это еще одна программа для создания онлайнвикторин, опросов и тестов. Студенты могут отвечать на тесты, которые создаются учителем, со всякого устройства, имеющего доступ к Интернету, к примеру, с планшетов, ноутбуков, смартфонов и т. д. В данной программе можно включать видеофрагменты. Темп проведения викторин и тестов регулируется введением ограничения времени для каждого вопроса. Учитель может ввести баллы за ответы на эти вопросы: за правильные ответы и за скорость. Для участия в тесте студентам достаточно просто открыть сервис и ввести PIN-код, предоставленный преподавателем со своего компьютера. В этой программе можно дублировать или редактировать тесты. Это позволяет преподавателю сэкономить свое временя на разработку тестов. 
Таким образом, современное программное обеспечение для создания тестов позволяет проводить качественное дистанционное тестирование. В то же время знание общих правил тестирования и рекомендаций по дистанционному тестированию, дают возможность преподавателю грамотно проводить тестирование удаленно.

Но важно помнить, что тесты не должны использоваться преподавателем как единственное средство контроля на уроках математики. Но как один из эффективных вариантов он имеет право присутствовать в учебном процессе, в том числе и на уроках математики, он позволяет оптимизировать работу над проверкой знаний студентов, «повысить мотивацию в изучении дисциплины «Математика», и как следствие, повысить качество знаний по дисциплине «Математика» [1].

\section{Сиисок литературы}

1. Глебова М.В. Использование математических онлайн-калькуляторов для повышения качества знаний по дисциплине «Математика» у бакалавров нематематического профиля // Лучшие практики «Вызов цифрой»: материалы Всерос. науч. конф. (Чебоксары, 8 апр. 2020 г.) / редкол.: Р.И. Кириллова [и др.] - Чебоксары: ИД «Среда», 2020.

2. Тюрикова О.А. Возможности использования дистанционной формы обучения в образовательном процессе / О.А. Тюрикова [Электронный ресурс]. - Режим доступа: https://infourok.ru/vozmozhnosti-ispolzovaniya-distancionnoy-formi-obucheniya-1507736.html

3. Любомирская Н.В. Теория и практика внедрения смешанного обучения в деятельность школы / Н.В. Любомирская, Е.Л. Рудик, Е.В. Чигирева [и др.] [Электронный ресурс]. Режим доступа: https://multiurok.ru/index.php/files/kursovaia-rabota-na-tiemu-tiestirovaniiekak-forma-kontrolia-v-obuchienii-matiematiki.html

Глебова Мария Владимировна канд. физ.-мат. наук, доцент Хрянина Ирина Михайловна студентка

Педагогический институт им. В.Г. Белинского ФГБОУ ВО «Пензенский государственный университет» г. Пенза, Пензенская область

\section{ИСПОЛЬЗОВАНИЕ ВОЗМОЖНОСТЕЙ СЕРВИСА GOOGLE CLASSROOМ ДЛЯ ОРГАНИЗАЦИИ ДИСТАНЦИОННОГО ПРАКТИКО- ОРИЕНТИРОВАННОГО ОБУЧЕНИЯ МАТЕМАТИКЕ}

Аннотация: статья посвящена анализу использования возможностей сервиса Google Classroom в процессе практико-ориентированного обучения математике. Основное внимание уделяется обзору функииональных возможностей сервиса Google Classroom с позиции повьшения эффективности учебного процесса. Раскрывается, как именно можно использовать ресурс для организациии практико-ориентированных задач, объединенных общзи сюжетом.

Ключевые слова: практико-ориентированное обучение, электронные образовательные ресурсы, Google Classroom, дистанционное обучение.

Изменения, происходящие в обществе в настоящее время, определяют новые подходы к модернизации и развитию образовательной системы

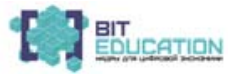


Российской Федерации. Основным требованием ФГОС к результатам освоения обучающимися основной образовательной программы основного общего образования является «развитие умений применять изученные понятия, результаты, методы для решения задач практического характера и задач из смежных дисциплин с использованием при необходимости справочных материалов, компьютера, пользоваться оценкой и прикидкой при практических расчётах» [3]. Согласно концепции развития математического образования в Российской федерации основным направлением современного образования должно стать формирование у учащихся способности применять полученные в школе знания и умения для решения конкретных жизненных задач. Поэтому необходимо организовать «практико-ориентированное обучение, направленное на развитие у учеников умений и навыков решения проблем повседневной жизни средствами математики» [2].

В марте 2020 года из-за пандемии коронавируса учебные заведения приняли решение о переходе на дистанционное обучение. В связи с этим все очные занятия были перенесены в онлайн-среду. Учителя, преподаватели и обучающиеся столкнулось с рядом проблем, но в тоже время новый формат обучения предоставил широкий спектр возможностей и перспектив для изменения и совершенствования образовательных систем. Масштабы внедрения Интернет-технологий в образовательный процесс определяются разумным стремлением участников сделать обучение более эффективным и интересным, с одной стороны, а также менее трудоемким и затратным по времени, с другой. Способствует этому процессу постоянная разработка различных виртуальных платформ и сервисов, которые производители программных продуктов свободно распространяют в академической среде. Одним из бесплатных веб-сервисов является Google Classroom.

Google Classroom - облачная платформа, организованная специально для обучения, доступная для всех владельцев личного аккаунта Google [1]. Данный ресурс предоставляет большие возможности для взаимодействия между учителем и учащимися, организации занятий в онлайн-формате, создания и управления учебными курсами. Он включает в себя множество средств для того, чтобы: создавать учебные курсы, делиться образовательными материалами, создавать, проверять и оценивать задачи в режиме реального времени, проверять уровень усвоения знаний и отслеживать прогресс успеваемости каждого, реализовать индивидуальный подход в обучении;

Главными особенностями сервиса Google Classroom является: простая настройка, экономия времени и бумаги (раздавать задания, контролировать выполнение, проверять задачи можно в одном сервисе), удобство, доступность (класс доступен бесплатно, для работы в сервисе можно использовать как компьютер, так и планшет или телефон), безопасность (в этом сервисе отсутствует реклама, а материалы и личные данные пользователей не попадают в другие сервисы) [1].

Рассмотрим возможности организации практико-ориентированного обучения математике школьников с использованием сервиса Google Classroom. Под практико-ориентированным обучением математике следует понимать деятельность, нацеленную на формирование у учащихся практических умений, необходимых в реальной жизни, посредством

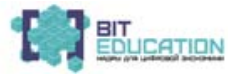


выполнения практических заданий и упражнений по математике. Основной целью практико-ориентированного метода обучения математике является создание педагогом таких условий, в рамках которых учащиеся имеют возможность реализовать свои потребности к познанию и исследованию, освоить различные формы учебной деятельности и научиться применять полученные знания в решении широкого круга жизненных проблем [2]. Большими возможностями для реализации данного метода обучения математике обладают задачи с практическим содержанием, так называемые, практико-ориентированные задачи. Это задачи, основной целью которых является формирование у учащихся умений и навыков, необходимых для применения полученных математических знаний в различных сферах практической жизни человека.

Выделим основные компоненты содержания практико-ориентированного метода обучения математике и то, как они могут быть реализованы с использованием сервиса Google класс.

1. Теоретическая часть.

Сервис Google Classroom предоставляет учителю большой выбор средств и методов организации взаимодействия с классом. Для ознакомления учащихся с теоретическим материалом можно проводить онлайнконсультации, добавлять видео-уроки и видео-лекции по математике. Возможности платформы Google Classroom в наполнении теоретической частью достаточно разнообразны. Это и лекции в электронном или видеоформате, и соответствующие разделы учебников, а также видеозаписи с YouTube.

2. Практическая (прикладная часть).

Для эффективного применения учащимися полученных теоретических знаний учитель может: публиковать задания, вопросы и материалы; рассылать объявления и начинать обсуждения; организовывать практические занятия в онлайн-режиме. B Google классе у обучающихся есть возможность делиться материалами, оставлять комментарии и общаться по электронной почте. Учитель постоянно получает информацию о выполненных работах, что позволяет ему оперативно проверять задания, ставить оценки и добавлять комментарии. Чтобы создать задание, нужно выбрать соответствующий пункт меню. Далее в диалоговом окне указать тематику, дать объяснения по оформлению и сроков выполнения, прикрепить конкретную задачу. Можно использовать любые формы: тесты с выбором одного или нескольких ответов, открытые задания, задания с использованием рисунков, диаграмм и видео и др. При этом разработать задание можно как для всех учащихся, так и для конкретного ученика.

3. Самостоятельная работа.

Данный ресурс позволяет создавать для учащихся индивидуальные задания для самостоятельной работы. Это позволяет проверить, как конкретный учащийся усвоил материал, а также своевременно выявить и устранить пробелы в знаниях. Учитель может предложить обучающимся решить индивидуально подобранную математическую задачу с практическим содержанием, проверочную работу и многие другие задания для самостоятельного выполнения. После того как ученик выполнил задание, сведения об этом автоматически поступают к учителю. Он может проверить правильность выполнения, выставить оценки, прокомментировать ответы. Если необходимо учитель может вернуть и удалить работу. 
4. Организация проектной деятельности учащихся.

Предполагает, как самостоятельную деятельность обучающихся, так и совместную с педагогом. Учащимся предлагается та или иная проблема, исследуя которую они должны получить вполне реальный, практический результат.

Для того чтобы грамотно и эффективно организовать практико-ориентированное обучение математике, учитель в своей работе должен опираться на следующие принципы: самостоятельности, свободы и сотрудничества. Google класс предоставляет возможности для реализации этих принципов. Для реализации принципа самостоятельности сервис Google предлагает множество различных источников для самостоятельной поисковой, исследовательской и практической деятельности учащихся (видеолекции, онлайн-семинары, электронные учебники и журналы, математические форумы и т. д.). Это позволяет организовать индивидуальный маршрут обучения, опираясь на особенности и возможности конкретного ученика. Принцип свободы реализуется в том, что этот сервис позволяет учащимся самостоятельно определяют какие ресурсы, они будут использовать в своей поисковой деятельности, отбирают материал, выбирают формы оформления и предоставления выполненных заданий и т. д. Также Google Classroom позволяет организовать продуктивное взаимодействие между всеми участниками образовательного процесса (онлайн-занятия, обсуждения), посредством которого учитель не только раскрывает содержание изучаемого материала, но и выстраивает сотрудничество, с учетом знаний и опыта учащихся, что позволяет тем самым реализовывать принцип сотрудничества.

Эффективным средством дистанционного практико-ориентированного обучения, позволяющим объединить все эти компоненты и принципы, является электронный курс по математике, созданный с помощью Google Classroom. Разработка таких курсов, направленных на формирование и закреплений умений, учащихся решать задачи с практическим содержанием становится всё более актуальной. Прежде всего это связано с включением таких заданий в контрольно-измерительные материалы ОГЭ и ЕГЭ по математике.

Например, в 2020 году в ОГЭ были включён блок практико-ориентированных задач, объединенных общим сюжетом. Как правило, учащимся предлагается план участка, схема или таблица, опираясь на которые они должны выполнить предложенные задания 1-5. Учитель сталкивается с проблемой: как организовать обучение школьников решению таких задач? Ведь их выполнение требует, чтобы у каждого учащегося перед глазами был раздаточный материал (план, чертеж, таблица и т. д.). В классе с большим количеством учеников, обеспечение каждого наглядным пособием требует от учителя достаточно больших затрат. Использование интерактивной доски тоже малоэффективно. В данном случае целесообразно организовать онлайн-обучение. Можно разработать электронный курс на платформе Google класс, направленный на развитие умения учащихся решать практико-ориентированные задачи ОГЭ по математике. Это позволит учителю обеспечить каждого ученика наглядным материалом для решения задания, а также выполнить большее количество заданий такого типа.

Кроме того, можно организовать индивидуальную проектную деятельность. Например, разработка плана своего домохозяйства или дачного участка и т. п. 
Анализ возможностей сервиса Google Classroom показал, что это удобный и простой инструмент дистанционного обучения, который расширяет рамки традиционных образовательных методов, обогащает их новыми возможностями. Использование Google Classroom позволяет учителю не только научить учащихся основным математическим понятиям и операциям, но и сформировать у них умение применять их в решении широкого круга практических задач. Особенно важным с точки зрения практикоориентированного обучения, является то, что данный ресурс позволяет существенно повысить скорость и качество взаимодействия между учителем и учащимися. Данный сервис предоставляет возможность найти новые подходы к организации практико-ориентированного обучения математике.

\section{Список литературы}

1. Google for Education [Электронный ресурс]. - Режим доступа: https://edu.google.com/ products/classroom/

2. Калугина Е.Ю. Образовательные возможности практико-ориентированного обучения учащихся: дис. ... канд. пед. наук. - Екатеринбург, 2000. - 215 с.

3. Федеральный государственный образовательный стандарт основного общего образования [Электронный ресурс]. - Режим доступа: https://fgos.ru/ (дата обращения: 12.10.2020).

Демина Наталья Викторовна канд. пед. наук, доцент

Сабанова Людмила Витальевна канд. пед. наук, доцент

Глинкина Екатерина Валерьевна студентка

ФГБОУ ВО «Волгоградский государственный социально-педагогический университет»

г. Волгоград, Волгоградская область

\section{ПРАКТИКА ВЫЯВЛЕНИЯ УРОВНЯ \\ СФОРМИРОВАННОСТИ ПОЗНАВАТЕЛЬНЫХ УУД У МЛАДШИХ ШКОЛЬНИКОВ \\ НА ВНЕКЛАССНЫХ ЗАНЯТИЯХ ПО МАТЕМАТИКЕ СРЕДСТВАМИ ЭЛЕКТРОННЫХ ОБРАЗОВАТЕЛЬНЫХ РЕСУРСОВ}

Аннотация: статья посвящена использованию электронных образовательных ресурсов и интерактивных средств обучения в рамках внеклассного занятия.

Ключевые слова: УУД, младиие икольники, электронные образовательные ресурсы.

За последние годы появилось достаточное количество исследований (А.А. Вихман, Н.С. Подходова, А.Ю. Попов, А.В. Рогожина, Н.А. Чуланова, Т.М. Шахова, и др.), посвященных изучению универсальных 
учебных действий в целом и познавательных в том числе, способам их развития, критериям диагностики и результативности.

Большую роль в увеличении мотивации и вовлеченности учащихся в образовательный процесс играет использование современных интерактивных средств обучения (интерактивная доска, электронные образовательные pecyрсы, Learning Apps, и т. д), так как традиционные способы подачи информации значительно уступают интерактивным.

Использование интерактивных средств обучения при организации внеклассной работы, направленной на развитие математических способностей обучающихся, позволяет выделить следующие плюсы:

- повышение производительности и наглядности;

- повышение активной мыслительной деятельности школьников;

- повышение уровня мотивации самостоятельной работы учащихся;

- формирование познавательных интересов;

- осуществление быстрой диагностики сформированности УУД.

Разработанный дидактический материал помогает выбрать тот или иной вид интерактивного средства обучения для проведения внеклассного занятия в начальных классах, а также дают возможность учителю еще на стадии подготовки внеклассной работы максимально детализировать ее содержание, эффективно отразив основные используемые интерактивные средства обучения, соответствующие теме внеклассной работы. Позволяет оценить реальность использования интерактивных средств обучения на каждом этапе внеклассной работы по математике.

Применяя на внеклассных занятиях мультимедийные презентации, интерактивные тесты, викторины, учитель не воздействует на результат обучения напрямую. Однако он вносит вклад в создание современной образовательной среды, формирует у учащихся полезные привычки - например, оценивать себя после выполнения заданий, быть готовыми работать в команде, быстро исправлять свои ошибки. Вследствие чего учащиеся привыкают к использованию цифровых ресурсов в образовательных целях.

Интересная форма подачи материала в виде веселых анимированных героев способствуют запоминанию и более успешному усвоению знаний, а также дают возможность ребенку получить опыт разрешения проблем.

Применение электронных образовательных ресурсов в обучении школьников позволяют не только сделать урок ярким, нестандартным, но и создают предпосылки для освоения способов деятельности.

Поскольку наглядно-образные компоненты мышления играют исключительно важную роль в жизни человека, то использование их в изучении материала повышают эффективность обучения.

Для исследования нами были выделены следующие познавательные действия:

- общеучебные действия (поиск и выделение необходимой информации, формирование познавательной цели);

- логические действия (умения анализировать, обобщать, сравнивать и классифицировать);

- постановка и решение проблемы (умения выделять и сравнивать стратегии решения логической задачи). 
Все это позволило выделить и обосновать три уровня сформированности познавательных УУД младших школьников средствами электронных образовательных ресурсов (низкий, средний, высокий).

Низкий уровень можно охарактеризовать нежеланием включаться в поисково-информационное направление учебной деятельности, несформированность познавательных целей и слабым проявлением логических действий, неумением выделять и сравнивать стратегии решения логической задачи, а также неумение быстро мыслить и находить правильное решение к задаче в программе «Отличник», после решения которых ученик получает соответствующую оценку, полученные оценки сохраняются - это даёт возможность ведения статистики оценок. Низкий уровень сформированности познавательного универсального действия общего приема решения задач - правильно решены 5 задач и менее.

Средний уровень характеризуется включением учащихся в поисковоинформационное направление учебной деятельности, недостаточная сформированность познавательных целей, у учащихся есть попытки выполнять логические действия, также они стараются выделять и сравнивать стратегии решения логической задачи, больше половины верно решённых задач в программе «Отличник». Средний уровень - правильно решены от 6 до 10 задач.

Высокий уровень определяется включением учащихся в поисково-информационное направление учебной деятельности, сформированность познавательных целей и проявлением логических действий, умением выделять и сравнивать стратегии решения логической задачи, умением быстро мыслить и находить верное решение к задаче в программе «Отличник». Высокий уровень - правильно решены 10 задач и более.

Использование заданий разного уровня помогает поддерживать интерес к изучению математики. Но их применение не должно вести к расслоению класса по уровню способностей. При дифференцированном подходе к учащимся значительно повышается уровень усвоения знаний, достигаются определённые положительные успехи в работе. У учащихся возникает уверенность в своих способностях. Всё это способствует активизации мыслительной деятельности учащихся и появлению положительная мотивация к процессу обучения.

Задания разного уровня предполагают дифференциацию содержания следующих заданий по уровню творчества, по уровню трудности и по объёму:

1. Дифференциация заданий по уровню творчества:

Задания разного уровня выбираются таким образом, чтобы были взаимосвязаны друг с другом. Например, творческое задание для третьего уровня должно содержать репродуктивную часть, предложенную для выполнения первого уровня.

2. Дифференциация заданий по уровню трудности:

На первом уровне предлагаются базовые задания, на втором и третьем уровнях более трудные задания.

Например:

Увеличение количества действий при решении задач (таблица). 
Таблица

\begin{tabular}{|c|c|c|}
\hline 1 уровень & 2 уровень & 3 уровень \\
\hline $\begin{array}{l}\text { Коля собрал } 16 \text { грибов, } \\
\text { а Маша - на } 3 \text { гриба } \\
\text { меньше, чем Коля. } \\
\text { Сколько грибов собрала } \\
\text { Маша? } \\
\text { Решение: } \\
16 \text { - } 3=13 \text { (грибов) }\end{array}$ & $\begin{array}{l}\text { У Пети } 6 \text { яблок, а у } \\
\text { Васи - в } 2 \text { раза больше. } \\
\text { Сколько яблок у них } \\
\text { обоих? } \\
\text { 1) } 6 \text { * } 2=12 \text { (яблок у } \\
\text { Пети) } \\
\text { 2) } 12+6=18 \text { (яблок у } \\
\text { Васи и Пети). }\end{array}$ & $\begin{array}{l}\text { Сын собрал } 18 \text { грибов. } \\
\text { Отец собрал на } 22 \text { гри- } \\
\text { бов больше, чем сын. } \\
\text { Мать собрала на } 4 \text { гри- } \\
\text { бов меньше отца. } \\
\text { Сколько всего грибов } \\
\text { собрала вся семья? } \\
\text { Решение: } \\
\text { 1) } 18+22=40 \text { (грибов } \\
\text { собрал отец) } \\
\text { 2) } 40 / 4=10 \text { (грибов } \\
\text { собрала мама) } \\
\text { 3) } 18+40+10=68 \\
\text { (грибов всего) }\end{array}$ \\
\hline
\end{tabular}

3. Дифференциация заданий по объему материала:

Дифференциация заданий по объёму материала планирует, что часть учащихся выполнит кроме основного задания ещё и дополнительные. Необходимость применения дифференциации заданий по объёму обусловлена разным темпом работы учащихся.

Учитывая описанные уровни, нами было разработано три внеклассных занятия по программе «Юный математик».

Тема первого занятия «Царииа наук».

Форма проведения: познавательно-развлекательная игра.

Цель: создать условия для формирования у учащихся математических способностей.

Задачи: способствовать формированию у учащихся приёмов мыслительной деятельности; способствовать развитию мышления, памяти связной речи детей; содействовать воспитанию чувства взаимопомощи в процессе коллективной работы.

Все учащиеся были разделены на три команды с учётом сформированности познавательной цели и логических действий. В каждой команде были учащиеся, у которых был выявлен низкий уровень сформированности познавательных универсальных учебных действий. Задания, были посильны всем учащимся.

Игра состояла из семи раундов. Первый раунд «Разминка». Всем командам предлагались блиц-вопросы из области математики. Например: «Назовите число, которое нельзя изобразить римскими цифрами?». Все команды успешно справились на данном этапе и сравняли счёт.

Второй раунд «Задание-шифровка». Командам были предложены зашифрованные слова, при помощи цифр. Например: 1) 9, 1, 5, 1, 25, 10. Каждой цифре соответствовала определённая буква. Учащимся с низким уровнем предлагалось расшифровать короткие слова, тем самым принести пользу команде. На данном этапе победу одержала первая команда, за счёт слаженной работы они быстрее справились с заданием.

Третий раунд «Ребусы». В данном задании учащимся с высоким уровнем познавательных универсальных учебных действий было легче справиться с заданием и быстро разгадать слово. Слабые ученики записывали 
результаты и старались включиться в работу со всей командой. В данном этапе все учащиеся закончили работу одновременно, сумев распределить обязанности в каждой команде. В этом раунде победу одержала вторая команда.

Четвёртый раунд «Сообрази». Данное задание способствовало развитию логики. Командам предлагалось передвинуть всего лишь одну спичку, для того, чтобы животное развернулось в другую сторону. В данном задании первыми оказалась вновь первая команда.

Пятый раунд «Больше слов». Из слова «треугольник» командам необходимо было составить как можно больше слов. Капитаны команд по очереди зачитывали результаты. В данном раунде победу одержала вторая команда. В данную работу с удовольствием включились все учащиеся.

Шестой раунд «Назови». Каждой команде необходимо было назвать 5 пословиц и поговорок, в которых встречаются числа и цифры. В данном раунде опередила первая команда. Данное задание вызвало затруднение у некоторых учащихся, это говорит о слабой мыслительной деятельности.

Седьмой раунд «Игра на компьютере» «Считай быстрее калькулятора». В данном раунде участвовали капитаны команд, остальные учащиеся помогали и поддерживали своих игроков. Капитанам команд необходимо было за минуту решить как можно больше выражений, а главное правильно. В данном раунде победу одержала третья команда.

В игре победу одержала первая команда. В работу включались все учащиеся, даже те, у кого низкий уровень сформированности познавательной деятельности.

В данном внеурочном занятии формируются логические действия. Учащиеся выстраивали логические цепи рассуждений при решении логических заданий, ребусов.

Тема второго занятия «Старинные единицьы измерений».

Форма проведения: игра-путешествие.

Цель: создание условий для формирования логического мышления учащихся.

Задачи: создать условие для ознакомления учащихся со старинами единицами измерения длины, площади, массы; способствовать развитию мышления, памяти связной речи детей; продолжить знакомить учащихся с традициями и обычаями русского народа.

Данное занятие было направлено на усиление логического мышления учащихся, особенно для тех, у кого низкий и средний уровень познавательной деятельности.

На данном занятии ребята отправились в путешествие вглубь веков, чтобы узнать, как измеряли в прошлом различные величины.

Ребята выбрали консультанта. Консультант получил карточку с указанием соотношения старинных единиц измерения. Путешествие состояло из станций. Первая станция Леоново 6 верст. За помощью обращались к консультанту, только после этого делали расчёты. Также каждому было предложено индивидуальное задание на карточках, если у учащихся возникали затруднение по величинам, то они обращались за помощью к консультанту.

Дальше по дороге, на аттракционах встретился Петрушка, который предложил разгадать загадки, чтобы проехать дальше. После этого 
встретился по дороге мужик. Он не мог определиться, сколько гороха купить для посева. Учащиеся помогли ему, решив задачу.

Всему классу понравилось путешествовать, но, чтобы машина времени вернула их обратно в класс, ребятам необходимо было разгадать кроссворд.

В ходе занятия все ребята были вовлечены в работу, слабые учащиеся выполняли задания наравне со всеми.

В связи с этим можно сделать вывод, что организованная работа подобным образом поспособствовала положительным результатам.

Работа на данном занятии была направлена на формирование общеучебных универсальных учебных действий. Данный этап является очень важным, так как от него зависит успешность выполняемого задания. Поэтому на уроке, решая задачи, учащиеся принимали решение не импульсивно, а обдуманно. Ребята анализировали, систематизировали и перерабатывали данную информацию, со стороны учителя ребятам были задавала наводящие вопросы: «Как вы думаете?» «Можно ли ответить на вопрос задачи сразу». Выбирали наиболее эффективный способ решения задач в зависимости от конкретных условий.

Тема третьего занятия «Занимательные задачи»

Форма проведения занятия: игра-путешествие.

Цель - способствовать формированию математических способностей, формирование приёмов мыслительной деятельности.

Задачи: способствовать пониманию способов решения нестандартных задач; способствовать развитию практического овладения и содержания логических понятий, формированию познавательных умений; способствовать формированию интереса к предмету, стремлению использовать математические знания в повседневной жизни.

На данном занятии ребята отправились в увлекательное путешествие по стране «Математика» на сказочном поезде. Первым препятствием на нашем пути открыть ворота. Для этого необходимо было сосчитать квадраты, по пути на поезде мы выполнили задание «Кто больше». Оно заключалось в том, что из слова «арифметика» нужно было составить как можно больше слов. Первая станция, к которой мы прибыли «Задачкино». Учащимся были предложены задачи в стихотворной форме, их легко было решить всем учащимся. Вторая станция, на которой мы оказались «Внимательная». На этой станции учащимся были представлены более сложные задачи. Например: в автобусе ехали 25 человек. На первой остановке вышли 7 человек, зашли 4 человека. На следующей остановке вышли 12 человек, зашли 5 человек. На следующей остановке вышли 8 человек, зашли 6 человек. На следующей остановке вышли 2 человека, зашли 16 человек. На следующей остановке вышли 5 человек. Сколько было остановок? Следующая станция «Догадкино». Учащиеся выполняли задания в парах. Им были предложены следующие задания: 1. Запиши число 7 при помощи четырех троек и знаков действий. Найди несколько решений.

Таким образом, использование электронных образовательных ресурсов и интерактивных средств обучения позволило сделать внеклассное занятие более занимательны, интересным и результативным.

\section{Список литературы}

1. Агаркова Н.В. Нескучная математика. 1 - 4 классы. Занимательная математика. Волгоград: Учитель, 2007.

2. Агафонова И. Учимся думать. Занимательные логические задачи, тесты и упражнения для детей 8-11 лет. - СПб., 1996.

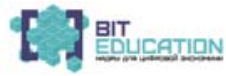


3. Белякова О.И. Занятия математического кружка. 3-4 классы. - Волгоград: Учитель, 2008 .

4. Лавриненко Т.А. Задания развивающего характера по математике. - Саратов: Лицей, 2002.

5. Узорова О.В. Вся математика с контрольными вопросами и великолепными игровыми задачами. 1-4 классы / О.В. Узорова, Е.А. Нефёдова. - М., 2004.

6. Занимательная математика. Смекай, отгадывай, считай. (Материалы для занятий с учащимися 1-4 классов. Логические и комбинаторные задачи, развивающие упражнения) / сост. Н.И. Удодова. - Волгоград: Учитель, 2008.

7. Подходова Н.С. Особенности формирования познавательных универсальных учебных действий (на примере сравнения) / Н.С. Подходова, Е.Ф. Фефилова // Вестник Северного (Арктического) федерального университета. Сер. Гуманитарные и социальные науки. 2013. - №4. - C. 139-146.

8. Тонких А.П. Логические игры и задачи на уроках математики. - Ярославль, 1997.

9. Чилингирова Л. Играя, учимся математике. Пособие для учителя: пер. с болг. / Л. Чилингирова, Б. Спиридонова. - М.: Просвещение, 1993.

10. Чопова С.В. Формирование познавательных универсальных учебных действий учащихся профильных классов: дис. ... канд. пед. наук / С. В. Чопова. - М., 2013. - 168 с.

11. Чуланова Н.А. Практическая составляющая модели развития познавательных универсальных учебных действий / Н.А. Чуланова // Актуальные вопросы регионального образования. - 2013. - №10. - С. 89-95.

12. Шахова Т.М. Формирование у учащихся 5-х классов познавательных и регулятивных универсальных учебных действий в работе с тематическим и рефлексивным языковыми портфелями при обучении русскому языку: автореф. дис. ... канд. пед. наук / Т.М. Шахова. Орел, 2014. - 16 c.

\section{Егорова Кристина Владимировна}

студентка

Орский гуманитарно-технологический институт (филиал) ФГБОУ ВО «Оренбургский государственный университет»

г. Орск, Оренбургская область

\section{ПРОФИЛЬНАЯ НАПРАВЛЕННОСТЬ ОБУЧЕНИЯ МАТЕМАТИКЕ В УСЛОВИЯХ СРЕДНЕГО ПРОФЕССИОНАЛЬНОГО ОБРАЗОВАНИЯ}

Аннотация: в статье предлагается один вариант решения проблемьл профильной направленности обучения математике специилистов среднего звена. Автором описана разработанная методика, модель, ход и результат экспериментальной проверки эффективности данной модели и методики теоретико-эмпирического исследования «Обеспечение качества образовательных прочессов в профессиональном образовании».

Ключевые слова: профильная направленность обучения, модель, методика, профессиональнье задачи, эксперимент.

Инновационное развитие экономики России, цифровизация социальноэкономических отношений, основу которой составляет математика, диктуют новые требования к качеству математической подготовки специалистов среднего звена. Перед средними профессиональными организациями в новых условиях рыночной экономики возникают следующие задачи: необходимость формирования у студентов адаптивной функции к 
использованию математического аппарата в профессиональной деятельности; необходимость реализации в учебно-воспитательном процессе гуманистической, развивающей функции с целью формирования личности, способной к творческому подходу относительно использования математических знаний на рабочем месте; реализация принципа профильной направленности обучения математике в среднем профессиональном образовании.

Решение указанных задач предполагает поиск новых путей, позволяющих подготовить из студента будущего специалиста среднего звена, ясно представляющего место математики на производстве, не теряющегося при возникновении каких-либо производственных ситуаций, требующих использование математического аппарата.

Основной задачей среднего профессионального образования является подготовка высококвалифицированных специалистов, конкурентоспособных на рынке труда, компетентных, ответственных, свободно владеющих своей профессией и ориентированных в смежных областях деятельности, способных к профессиональному росту и профессиональной мобильности в условиях информатизации общества и развития новых наукоемких технологий. Математика как фундаментальная дисциплина имеет большие возможности для формирования ключевых компетенций специалиста, как профессиональных, так и личностных. В силу специфики своего содержания данный учебный предмет формирует способность к самообразованию, поиску и усвоению новой информации, умение планировать и адекватно оценивать свои действия, принимать решения в стандартных и нестандартных ситуациях, работать в коллективе и команде, развивает силу и гибкость ума, способность к аргументации и другие качества, необходимые современному специалисту. Цель обучения математике в техникуме состоит в том, чтобы студент, во-первых, получил фундаментальную математическую подготовку в соответствии с программой, а во-вторых, овладел навыками математического моделирования в области будущей профессиональной деятельности.

В данной работе рассматриваются результаты, полученные в рамках реализации на кафедре математики, информатики и физики Орского гуманитарно-технологического института (филиала) ОГУ теоретико-эмпирического исследования «Обеспечение качества образовательных процессов в профессиональном образовании» (номер госрегистрации-АААА16-116020960161-9) по созданию модели обеспечения профильной направленности обучения математике в условиях среднего профессионального образования. Цель исследования заключалась в разработке методики обучения математике, использование которой обеспечит готовность будущих специалистов среднего звена к использованию математического аппарата в профессиональной деятельности. Гипотезой исследования являлось предположение о том, что профильная направленность обучения математике в условиях среднего профессионального образования будет обеспечена, если:

- будут определены теоретические аспекты обеспечения профильной направленности обучения математике в условиях среднего профессионального образования;

- будет спроектирована модель обеспечения профильной направленности обучения математике в условиях среднего профессионального образования; 
- будет разработана, апробирована и экспериментально обоснована методика реализации модели обеспечения профильной направленности обучения математике в условиях среднего профессионального образования.

Разработанная модель включает в себя взаимосвязанные компоненты: целевой, содержательной, деятельностно-процессуальный и результативно-оценочный.

Целевой компонент - обеспечить профильную направленность обучения математике специалистов среднего звена.

Содержательной частью модели являться электронное учебное пособие «Математика для специалистов среднего звена». Пособие содержит задачи профильной направленности, творческую работу и проверочные тесты. В данное пособие входят темы:

- корни, степени и логарифмы;

- прямые и плоскости в пространстве;

- комбинаторика;

- координаты и векторы;

- основы тригонометрии;

- функции и графики;

- многогранники и круглые тела;

- начало математического анализа;

- уравнения и неравенства.

Деятельностно-процессуальный компонент включает практическое обучение и внеурочную работу.

Результативно-оценочный компонент проводится с помощью проверочных работ и тестов по изученным темам, которые были созданы в Google Form.

Методика заключается в том, что на занятиях разбираются и решаются задачи профильной направленности. Так же домашнее задание и внеурочную деятельность выдают с помощью электронного пособия «Математика для специалистов среднего звена». Оно создано с помощью бесплатной платформы Google Site и очень удобное в использовании.

B процессе исследования была разработана дополнительная профессиональная программа повышения квалификации «Профильная направленность обучения математике специалистов среднего звена в условиях дополнительного образования».

Программа предназначена для учителей математики средних специальных учебных заведений, методистов и преподавателей педагогических колледжей, специалистов методических служб и органов, осуществляющих управление в сфере образования и ориентирована на формирование у обучающихся конкретных знаний, умений, навыков относительно подготовки в области методической работы обучения математике специалистов среднего звена.

В программу входят 4 модуля:

1) профильная направленность обучения математике специалистов среднего звена в процессе формирования понятий;

2) профильная направленность в обучении математическим суждениям и их доказательств;

3) реализация профильной направленности обучения началам математического анализа в организациях среднего профессионального образования; 
4) методы решения практико-ориентированных заданий по математическому анализу в организациях среднего профессионального образования.

Задача эксперимента провести занятия с использованием методики и среды Google Site (в экспериментальной группе) и без использования (в контрольной группе) у обучающихся 1 курса.

Для проверки эффективности использования методики использовался критерий Вилконсона-Манна-Уитни и программа «Педагогическая статистика».

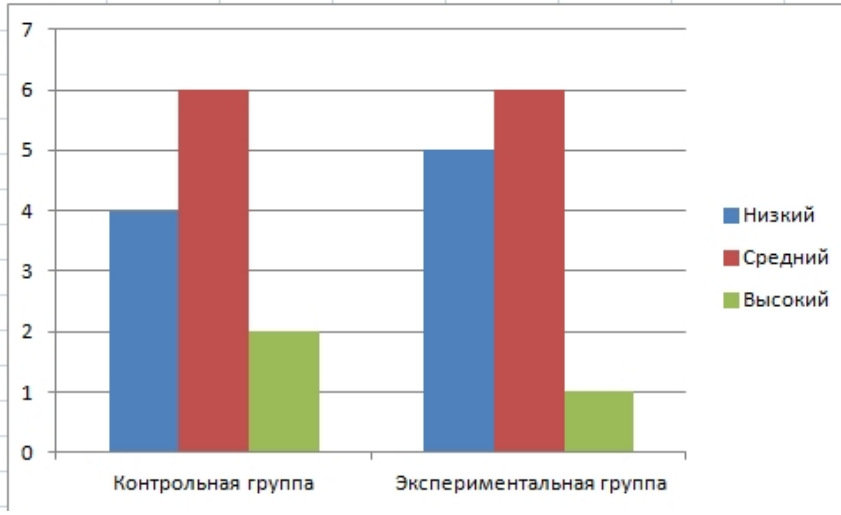

Рис. 1. Сравнительный анализ результатов контрольной и экспериментальной группы до эксперимента

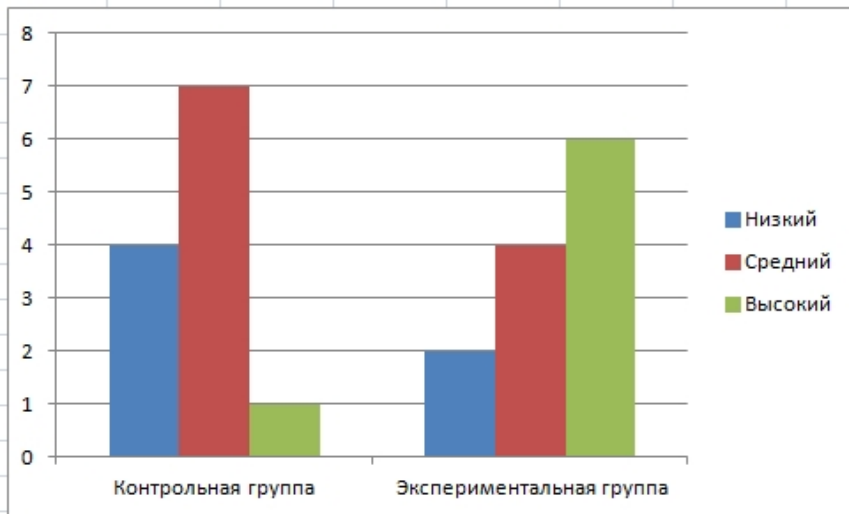

Рис. 2. Сравнительный анализ результатов контрольной и экспериментальной группы после эксперимента 
В результате данного эксперимента в группах возникло различие уровня знаний, вызванное эффективностью использования методики с применением пособия в Google Site на занятиях.

\section{Сиисок литературы}

1. Егорова К.В. Профильная направленность обучения математике как современная проблема среднего профессионального образования: перспективы / К.В. Егорова // Актуальные проблемы методики обучения информатике и математике в современной школе: материалы Междунар. науч.-практ. интернет-конференции / под ред. Л.Л. Босовой, Д.И. Павлова. - М., 2019. $-765 \mathrm{c}$.

2. Гладкая Е.О. Обеспечение качества математической подготовки специалистов по обслуживанию электрического и электромеханического оборудования как проблема среднего профессионального образования / Е.О. Гладкая, Т.И. Уткина // Всероссийская научно-методическая конференция города Оренбург / Университетский комплекс как региональный центр образования, науки и культуры. - Оренбург, 2019. - 3562 с.

3. Мордкович А.Г. Профессионально-педагогическая направленность специальной подготовки учителя математики в педагогическом институте: дис. ... д-ра пед. наук. - М., 1986. $-358 \mathrm{c}$.

4. Уткина Т.И. Теоретические основы управления качеством подготовки учителя математики: дис. ... д-ра пед. наук. - М., 2005. - 396 с.

\section{Елизарова Екатерина Юрьевна старший преподаватель \\ Красильникова Светлана Владимировна студентка}

ФГБОУ ВО «Нижегородский государственный педагогический университет им. К. Минина» г. Нижний Новгород, Нижегородская область

\section{ИНТЕРПОЛЯЦИОННЫЕ ФОРМУЛЫ НЫЮТОНА КАК ОСНОВА ЧИСЛЕННОГО ДИФФЕРЕНЦИРОВАНИЯ}

Аннотация: данная статья посвящена численному дифференцированию, которое является основой для вычислительных методов, рассматриваемых как в школьном, так и в вузовском курсе математики. Авторами рассмотрень формуль приближенного дифференцирования как альтернативного способа дифференцииции функций. Особое внимание уделяется исследованию области применимости данных формул, решаеMblx в MS Excel.

Ключевые слова: численные методы, численное дифференцирование, интерполяционнье формуль Ньютона.

Актуальность данной темы «Интерполяционные формулы Ньютона как основа численного дифференцирования» заключается в противоречии между широкой применимостью сложного дифференциального исчисления в различных науках, таких, как экономика, физика, астрономия, и недостаточной проработанностью вопроса о методах вычисления значения производной дискретно заданной функции. 
И. Ньютон и Г. Лейбниц являются основоположниками дифференциального исчисления. Оно было создано в XVII веке на основе следующих задач:

- о разыскании касательной к произвольной линии;

- о разыскании скорости при произвольном законе движения [1].

Различные методы численного дифференцирования обширно применяются на практике, когда численно нужно решить одно или несколько дифференциальных уравнений. Методы численного дифференцирования используются в тех случаях, когда нужно отыскать какую-либо производную, поиск которой аналитически затруднен или элементарно невыполним, если функция задана таблично. В таких случаях исходную функцию у (х) замещают, аппроксимируют более простой функцией $\varphi(\mathrm{x})$ и считают, собственно, что приближенно верно равенство: у $(\mathrm{x})=\varphi^{\prime}(\mathrm{x})$ [3].

В этой работе, мы расскажем о первой и второй интерполяционных формулах Ньютона, как они выводятся и для чего они необходимы. Кроме этого будут рассмотрены конкретные примеры нахождения приближённого значения производной функции по заданным табличным данным.

Рассмотрим первую интерполяционную формулу Ньютона.

Пусть задана функция $\mathrm{y}=\mathrm{f}(\mathrm{x})$ на отрезке $\left[\mathrm{x}_{0}, \mathrm{x}_{\mathrm{n}}\right]$, который разбит на $\mathrm{n}$ одинаковых отрезков (случай равноотстоящих значений аргумента). $\Delta \mathrm{x}=$ $\mathrm{h}=$ const. Для каждого узла $\mathrm{x}_{0}, \mathrm{x}_{1}=\mathrm{x}_{0}+\mathrm{h}, \ldots, \mathrm{x}_{\mathrm{n}}=\mathrm{x}_{0}+\mathrm{n} \cdot \mathrm{h}$ определены значения функции в виде: $\mathrm{f}\left(\mathrm{x}_{0}\right)=\mathrm{y}_{0}, \mathrm{f}\left(\mathrm{x}_{1}\right)=\mathrm{y}_{1}, \ldots, \mathrm{f}\left(\mathrm{x}_{\mathrm{n}}\right)=\mathrm{y}_{\mathrm{n}}$.

Конечные разности первого порядка имеют следующий вид:

$$
\begin{gathered}
\Delta \mathrm{y}_{0}=\mathrm{y}_{1}-\mathrm{y}_{0} \\
\Delta \mathrm{y}_{1}=\mathrm{y}_{2}-\mathrm{y}_{1} \\
\quad \cdots \ldots . \\
\Delta \mathrm{y}_{\mathrm{n}-1}=\mathrm{y}_{\mathrm{n}}-\mathrm{y}_{\mathrm{n}-1} .
\end{gathered}
$$

Конечные разности второго порядка имеют следующий вид:

$$
\begin{aligned}
& \Delta^{2} \mathrm{y}_{0}=\Delta \mathrm{y}_{1}-\Delta \mathrm{y}_{0} \\
& \Delta^{2} \mathrm{y}_{1}=\Delta \mathrm{y}_{2}-\Delta \mathrm{y}_{1}
\end{aligned}
$$

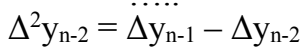

Аналогично определяются конечные разности высших порядков:

$$
\begin{gathered}
\Delta^{\mathrm{k}} \mathrm{y}_{0}=\Delta^{\mathrm{k}-1} \mathrm{y}_{1}-\Delta^{\mathrm{k}-1} \mathrm{y}_{0} \\
\Delta^{\mathrm{k}} \mathrm{y}_{1}=\Delta^{\mathrm{k}-1} \mathrm{y}_{2}-\Delta^{\mathrm{k}-1} \mathrm{y}_{1} \\
\Delta^{\mathrm{k}} \mathrm{y}_{\mathrm{i}}=\Delta^{\mathrm{k}-1} \mathrm{y}_{\mathrm{i}+1}-\dddot{\Delta}^{\dddot{k}-1} \mathrm{y}_{\mathrm{i}, \mathrm{i}}, \mathrm{i}=0,1, \ldots, \mathrm{n}-\mathrm{k}
\end{gathered}
$$

Заметим, что конечные разности функций удобно располагать и подсчитывать в таблицах, например, с помощью MS Excel.

Пусть для функции $\mathrm{y}=\mathrm{f}(\mathrm{x})$ заданы значения $\mathrm{y}_{\mathrm{i}}=\mathrm{f}\left(\mathrm{x}_{\mathrm{i}}\right)$ для равностоящих значений независимых переменных: $\mathrm{x}_{\mathrm{n}}=\mathrm{x}_{0}+\mathrm{n} \cdot \mathrm{h}$, где $\mathrm{h}-$ шаг интерполяции. Необходимо найти полином $\mathrm{P}_{\mathrm{n}}(\mathrm{x})$ степени не выше $\mathrm{n}$, принимающий в точках (узлах) $\mathrm{x}_{\mathrm{i}}$ значения: $\mathrm{P}_{\mathrm{n}}\left(\mathrm{x}_{\mathrm{i}}\right)=\mathrm{y}_{\mathrm{i}}, \mathrm{i}=0, . ., \mathrm{n}$. Запишем интерполирующий полином в виде:

$$
\begin{aligned}
& P_{n}(x)=a_{0}+a_{1}\left(x-x_{0}\right)+a_{2}\left(x-x_{0}\right)\left(x-x_{1}\right)+\cdots \\
& +a_{n}\left(x-x_{0}\right)\left(x-x_{n-1}\right)
\end{aligned}
$$

Задача построения многочлена сводится к определению коэффициентов $\mathrm{a}_{\mathrm{i}}$ из условий:

$$
\begin{gathered}
\mathrm{P}_{\mathrm{n}}\left(\mathrm{x}_{0}\right)=\mathrm{y}_{0} \\
\ldots \\
\text { BIT }
\end{gathered}
$$




$$
\mathrm{P}_{\mathrm{n}}\left(\mathrm{x}_{\mathrm{n}}\right)=\mathrm{y}_{\mathrm{n}}
$$

Полагаем в интерполирующий полиноме $\mathrm{x}=\mathrm{x}_{0}$, тогда, т.к. второе, третье и другие слагаемые равны $0, \mathrm{P}_{\mathrm{n}}\left(\mathrm{x}_{0}\right)=\mathrm{y}_{0}=\mathrm{a}_{0} \mathrm{a}_{0}=\mathrm{y}_{0}$. Найдем коэффициент $\mathrm{a}_{1}$. При $\mathrm{x}=\mathrm{x}_{1}$ получим:

$$
\begin{gathered}
P_{n}\left(x_{1}\right)=y_{1}=y_{0}+a_{1}\left(x_{1}-x_{0}\right) ; \\
y_{1}=y_{0}+a_{1}\left(x_{1}-x_{0}\right) \\
a_{1}=\frac{y_{1}-y_{0}}{x_{1}-x_{0}}=\frac{\Delta y_{0}}{h}
\end{gathered}
$$

Для определения $\mathrm{a}_{1}$ составим конечную разность второго порядка. При $\mathrm{x}=\mathrm{x}_{1}$ получим:

$$
\begin{gathered}
P_{n}\left(x_{2}\right)=y_{2}=y_{0}+\frac{\Delta y_{0}}{h}\left(x_{2}-x_{0}\right)+a_{2}\left(x_{2}-x_{0}\right)\left(x_{2}-x_{1}\right)=y_{0}+2 \Delta y_{0}+a_{2} 2 h^{2}, \\
a_{2}=\frac{y_{2}-y_{0}-2 \Delta y_{0}}{2 h^{2}}=\frac{y_{2}-y_{0}-2 y_{1}+2 y_{0}}{2 h^{2}}=\frac{y_{2}-2 y_{1}+y_{0}}{2 h^{2}} \\
=\frac{\left(y_{2}-y_{1}\right)-\left(y_{1}-y_{0}\right)}{2 h^{2}}=\frac{\Delta y_{1}-\Delta y_{1}}{2 h^{2}}=\frac{\Delta^{2} y_{0}}{2 ! h^{2}}
\end{gathered}
$$

Аналогично можно найти другие коэффициенты. Общая формула имеет вид.

$$
a_{k}=\frac{\Delta^{k} y_{0}}{k ! h^{k}}, k=1 . . n
$$

Подставляя эти выражения в формулу полинома, получаем:

$$
\begin{gathered}
P_{n}(x)=y_{0}+\frac{\Delta y_{0}}{1 ! h}\left(x-x_{0}\right)+\frac{\Delta^{2} y_{0}}{2 ! h^{2}}\left(x-x_{0}\right)\left(x-x_{1}\right)+\cdots \\
+\frac{\Delta^{n} y_{0}}{n ! h^{n}}\left(x-x_{0}\right) \ldots\left(x-x_{n-1}\right)
\end{gathered}
$$

где $\mathrm{x}_{\mathrm{i}}, \mathrm{y}_{\mathrm{i}}-$ узлы интерполяции; $\mathrm{x}-$ текущая переменная; $\mathrm{h}-$ разность между двумя узлами интерполяции $\mathrm{h}$ - величина постоянная, т.е. узлы интерполяции равноотстоят друг от друга.

$$
\begin{gathered}
P_{n}(x)=y_{0}+\frac{\Delta y_{0}}{1 ! h}\left(x-x_{0}\right)+\frac{\Delta^{2} y_{0}}{2 ! h^{2}}\left(x-x_{0}\right)\left(x-x_{1}\right)+\cdots+\frac{\Delta^{n} y_{0}}{n ! h^{n}}\left(x-x_{0}\right) \ldots(x \\
\left.-x_{n-1}\right)
\end{gathered}
$$

Этот многочлен называют интерполяционным полиномом Ньютона для интерполяции в начале таблицы (интерполирование «вперед») или первым полиномом Ньютона. Для практического использования этот полином записывают в преобразованном виде, вводя обозначение $t=\frac{\left(x-x_{0}\right)}{h}$, тогда

$$
P_{n}(x)=y_{0}+t \cdot \Delta y_{0}+\frac{t(t-1)}{2 !} \cdot \Delta^{2} y_{0}+\cdots+\frac{t(t-1) \ldots(t-n+1)}{n !} \cdot \Delta^{n} y_{0}
$$

Эта формула применима для вычисления значений функции для значений аргументов, близких к началу интервала интерполирования. Для получения выражения для приближённого дифференцирования по первой интерполяционной формуле Ньютона, необходимо исходную первую интерполяционную формулу Ньютона продифференцировать [2; 4]. 


$$
\begin{aligned}
P_{n}(x)= & y_{0}+t \cdot \Delta y_{0}+\frac{t \cdot(t-1)}{2 !} \cdot \Delta^{2} y_{0}+\frac{t(t-1)(t-2)}{3 !} \cdot \Delta^{3} y_{0} \\
& +\frac{t \cdot(t-1)(t-2)(t-3)}{4 !} \cdot \Delta^{4} y_{0} \ldots+\frac{t(t-1) \ldots(t-n+1)}{n !} \cdot \Delta^{n} y_{0}
\end{aligned}
$$

Производя перемножение биномов выражения, получим:

$$
\begin{aligned}
P_{n}(x) & =y_{0}+t \Delta y_{0}+\frac{t^{2}-\mathrm{t}}{2} \cdot \Delta^{2} y_{0}+\frac{t^{3}-3 t^{2}+2 t}{6} \cdot \Delta^{3} y_{0} \\
& +\frac{t^{4}-6 t^{3}+11 t^{2}-6 \mathrm{t}}{24} \cdot \Delta^{4} y_{0} \\
& +\frac{t^{5}-10 t^{4}+35 t^{3}-50 t^{2}+24 t}{120} \cdot \Delta^{5} y_{0}+\cdots
\end{aligned}
$$

Так как $\frac{d y}{d x}=\frac{d y}{d t} * \frac{d t}{d x}=\frac{1}{h} \frac{d y}{d t}$, то

$$
\begin{aligned}
f^{\prime}(x) & =\frac{1}{h}\left[\Delta y_{0}+\frac{2 t-1}{2} \cdot \Delta^{2} y_{0}+\frac{3 t^{2}-6 \mathrm{t}+2}{6} \cdot \Delta^{3} y_{0}\right. \\
& +\frac{2 t^{3}-9 t^{2}+11 \mathrm{t}-3}{12} \cdot \Delta^{4} y_{0}+\cdots
\end{aligned}
$$

Рассмотрим иллюстрацию применения формул на примере.

Пример 1. Вычислим приближенное значение производной функции $\mathrm{f}$ $(\mathrm{x})=\sin (\mathrm{x})$ в точке $x=0,62$, с использованием формулы, основанной на первой интерполяционной формуле Ньютона. Найдем абсолютную погрешность результата.

Пусть задана точка $x=0,62$ и функция, заданная с помощью следующей таблицы.

$$
\begin{array}{llllllll} 
& & & & & & & \text { Таблица } \\
\mathrm{x} & 0,6 & 0,7 & 0,8 & 0,9 & 1,0 & 1,1 & 1,2 \\
\operatorname{Sin}(\mathrm{x}) & 0,5646 & 0,6442 & 0,7174 & 0,7833 & 0,8415 & 0,8912 & 0,9320
\end{array}
$$

Определим к какому концу таблицы, заданная точка $x$ располагается ближе. Так как точка располагается ближе к началу интервала интерполирования, то для нахождения производной воспользуемся первой интерполяционной формулой Ньютона:

$$
\begin{aligned}
f^{\prime}(x)=\frac{1}{h}\left[\Delta y_{0}+\right. & \frac{2 t-1}{2} \cdot \Delta^{2} y_{0}+\frac{3 t^{2}-6 \mathrm{t}+2}{6} \cdot \Delta^{3} y_{0}+\frac{2 t^{3}-9 t^{2}+11 \mathrm{t}-3}{12} \cdot \Delta^{4} y_{0} \\
& +\ldots
\end{aligned}
$$

Составим таблицу конечных разностей. Для удобства подсчета предлагается использовать программу Excel (рис. 1). 


\begin{tabular}{|l|r|r|r|r|r|r|r|}
\hline yi & \multicolumn{1}{|c|}{$\Delta \mathrm{y} 0$} & $\Delta 2 \mathrm{y} 0$ & $\Delta 3 \mathrm{y} 0$ & $\Delta 4 \mathrm{y} 0$ & $\Delta 50$ & $\Delta 6 \mathrm{y} 0$ \\
\hline $\mathrm{y0}$ & 0,0796 & $-0,0064$ & $-0,0009$ & 0,0005 & $-0,0009$ & 0,0017 \\
\hline $\mathrm{y} 1$ & 0,0732 & $-0,0073$ & $-0,0004$ & $-0,0004$ & 0,0008 & \\
\hline y2 & 0,0659 & $-0,0077$ & $-0,0008$ & 0,0004 & & \\
\hline y3 & 0,0582 & $-0,0085$ & $-0,0004$ & & & \\
\hline y4 & 0,0497 & $-0,0089$ & & & & \\
\hline y5 & 0,0408 & & & & & \\
\hline y6 & & & & & & \\
\hline
\end{tabular}

Рис. 1

Рассчитаем приближенное значение производной функции $\mathrm{f}(\mathrm{x})=$ $\sin (\mathrm{x})$ в точке $x=0,62$. Полагая, что $\mathrm{x}_{0}=0,6, \mathrm{x}=0,62, \mathrm{~h}$ (шаг интерполяции) $=0,1$, найдем $t=\frac{\left(x-x_{0}\right)}{h}$. Подставляя в формулу исходные данные, получим $\mathrm{t}=0,2$.

$$
\begin{gathered}
f^{\prime}(0,62)=\frac{1}{0,1}\left[0,0796+\frac{2 * 0,2-1}{2} \cdot(-0,0064)+\frac{3(0,2)^{2}-6+2}{6} \cdot(-0,0009)\right. \\
+\frac{2 \cdot(0,2)^{3}-9 \cdot(0,2)^{2}+11 \cdot(0,2)-3}{12} \cdot(-0,0005)
\end{gathered}
$$

Для подсчета приближенного значения производной также воспользуемся программой Excel. В результате получим, что

$$
f^{\prime}(0,62)=0,8133433
$$

Вычислим абсолютную погрешность результата. Учитывая, что

$$
f^{\prime}(x)=\cos (x)
$$

то $f^{\prime}(0,62)=0,813878$. Абсолютная погрешность результата будет равна

$$
\Delta=|0,813878-0,8133433|=0,0005351
$$

Таким образом, можно сделать вывод, что между производной, найденной по формуле Ньютона и производной, найденной стандартным способом, существует минимальная погрешность.

Рассмотрим вторую интерполяционную формулу Ньютона [4].

Второй интерполяционный полином Ньютона применяется для нахождения значений функций в точках, расположенных в конце интервала интерполирования. Запишем интерполяционный многочлен в виде:

$$
\begin{aligned}
P_{n}(x) & =a_{0}+a_{1}\left(x-x_{n}\right)+a_{2}\left(x-x_{n}\right)\left(x-x_{n-1}\right)+\cdots \\
& +a_{n}\left(x-x_{n}\right)\left(x-x_{n-1}\right) \ldots\left(x-x_{1}\right)
\end{aligned}
$$

Коэффициенты $\mathrm{a}_{0}, \mathrm{a}_{1}, \ldots, \mathrm{a}_{\mathrm{n}}$ определяем из условия: $\mathrm{P}_{\mathrm{n}}\left(\mathrm{x}_{\mathrm{i}}\right)=\mathrm{y}_{\mathrm{i}} \mathrm{i}=0, \ldots, \mathrm{n}$. Полагаем в интерполяционном многочлене $\mathrm{x}=\mathrm{x}_{\mathrm{n}}$, тогда

Полагаем $\mathrm{x}=\mathrm{x}_{\mathrm{n}-1}$, тогда:

$$
\begin{gathered}
P_{n}\left(x_{n}\right)=a_{0} \\
P_{n}\left(x_{n}\right)=y_{n}=a_{0}, \\
a_{0}=y_{n}
\end{gathered}
$$

$$
P_{n}\left(x_{n-1}\right)=y_{n-1}=y_{n}+a_{1}\left(x_{n-1}-x_{n}\right), h=x_{n}-x_{n-1}
$$

Следовательно, $a_{1}=\frac{y_{n}-y_{n-1}}{h}=\frac{\Delta y_{n-1}}{h}$. 
Полагаем $\mathrm{x}=\mathrm{x}_{\mathrm{n}-2}$, тогда

$$
\begin{gathered}
P_{n}\left(x_{n-2}\right)=y_{n-2}=y_{n}+\frac{\Delta y_{n-1}}{h}\left(x_{n-2}-x_{n}\right)+a_{2}\left(x_{n-2}-x_{n}\right)\left(x_{n-2}-x_{n-1}\right), \\
y_{n-2}=y_{n}+\frac{\Delta y_{n-1}}{h}(-2 h)+a_{2} * 2 h^{2}=y_{n}-2 \Delta y_{n-1}+a_{2} 2 h^{2}, \\
a_{2}=\frac{\Delta^{2} y_{n-2}}{2 ! h^{2}}
\end{gathered}
$$

Аналогично можно найти другие коэффициенты многочлена:

$$
\begin{gathered}
a_{3}=\frac{\Delta^{3} y_{n-3}}{3 ! h^{3}} \\
a_{n}=\frac{\Delta^{n} y_{0}}{n ! h^{n}}
\end{gathered}
$$

Подставляя эти выражения в формулу (1), получим вторую интерполяционную формулу Ньютона или многочлен Ньютона для интерполирования «назад».

Введем обозначения:

$$
\begin{aligned}
P_{n}(x)= & y_{n}+\frac{\Delta y_{n-1}}{h}\left(x-x_{n}\right)+\frac{\Delta^{2} y_{n-2}}{2 ! h^{2}}\left(x-x_{n}\right)\left(x-x_{n-1}\right) \\
& +\frac{\Delta^{3} y_{n-3}}{3 ! h^{3}}\left(x-x_{n}\right)\left(x-x_{n-1}\right)\left(x-x_{n-2}\right)+\cdots \\
& +\frac{\Delta^{n} y_{0}}{n ! h^{n}}\left(x-x_{n}\right)\left(x-x_{n-1}\right) \ldots\left(x-x_{1}\right),
\end{aligned}
$$

$$
\begin{gathered}
\frac{x-x_{n}}{h}=t \text { или } x=x_{n}+t h \\
\frac{x-x_{n-1}}{h}=\frac{x-\left(x_{n}-h\right)}{h}=t+1 \\
\frac{x-x_{n-2}}{h}=\frac{x-\left(x_{n-1}-2 h\right)}{h}=t+2 \\
\frac{x-x_{1}}{h}=\frac{x\left(x_{n}-2 h\right)}{h}=t+n-1
\end{gathered}
$$

Произведя замену, получим

$$
P_{n}(x)=y_{n}+t \Delta y_{n-1}+\frac{t(t+1)}{2 !} \Delta^{2} y_{n-2}+\cdots+\frac{t(t+1) \ldots(t+n-1)}{n !} \Delta^{n} y_{0}
$$

Это вторая формула Ньютона для интерполирования «назад» $[3 ; 4]$. Для получения выражения для приближённого дифференцирования по второй интерполяционной формуле Ньютона, необходимо исходную вторую интерполяционную формулу Ньютона продифференцировать.

$$
\begin{gathered}
P_{n}(x)=y_{\mathrm{n}}+t \cdot \Delta y_{\mathrm{n}-1}+\frac{t(t+1)}{2 !} \cdot \Delta^{2} y_{\mathrm{n}-2}+\frac{t(t+1)(t+2)}{3 !} \cdot \Delta^{3} y_{\mathrm{n}-3} \\
+\frac{t(t+1)(t+2)(t+3)}{4 !} \cdot \Delta^{4} y_{\mathrm{n}-4}+\cdots \\
+\frac{t(t+1) \ldots(t+n-1)}{n !} \cdot \Delta^{n} y_{0}
\end{gathered}
$$


Производя перемножение биномов выражения, получим:

$$
\begin{aligned}
P_{n}(x)= & y_{\mathrm{n}}+t \cdot \Delta y_{\mathrm{n}-1}+\frac{t^{2}+\mathrm{t}}{2} \cdot \Delta^{2} y_{\mathrm{n}-2}+\frac{t^{3}+3 t^{2}+2 t}{6} \cdot \Delta^{3} y_{\mathrm{n}-3} \\
& +\frac{t^{4}+6 t^{3}+11 t^{2}+6 \mathrm{t}}{24} \cdot \Delta^{4} y_{\mathrm{n}-4} \\
& +\frac{t^{5}+10 t^{4}+35 t^{3}+50 t^{2}+24 t}{120} \cdot \Delta^{5} y_{\mathrm{n}-5}+\cdots
\end{aligned}
$$

Так как $\frac{d y}{d x}=\frac{d y}{d t} * \frac{d t}{d x}=\frac{1}{h} \frac{d y}{d t}$ то

$$
\begin{aligned}
f^{\prime}(x) & =\frac{1}{h}\left[\Delta y_{\mathrm{n}-1}+\frac{2 t+1}{2} \cdot \Delta^{2} y_{\mathrm{n}-2}+\frac{3 t^{2}+6 \mathrm{t}+2}{6} \cdot \Delta^{3} y_{\mathrm{n}-3}\right. \\
& \left.+\frac{2 t^{3}+9 t^{2}+11 \mathrm{t}+3}{12} \cdot \Delta^{4} y_{\mathrm{n}-4}+\cdots\right]
\end{aligned}
$$

Проиллюстрируем вычисление производной функции на основе второй интерполяционной формулы Ньютона.

Пример 2. Вычислим приближенное значение производной функции $\mathrm{f}$ $(\mathrm{x})=\cos (\mathrm{x})$ в точке $x=1,59$, с использованием формулы, основанной на второй интерполяционной формуле Ньютона. Найдем абсолютную погрешность результата.

Пусть функция задана в следующей табличной форме.

\begin{tabular}{|l|r|r|r|r|r|r|r|}
\hline $\mathrm{x}$ & 1 & 1,1 & 1,2 & 1,3 & 1,4 & 1,5 & 1,6 \\
\hline $\cos (\mathrm{x})$ & 0,8415 & 0,8912 & 0,932 & 0,9636 & 0,9854 & 0,9975 & 0,9996 \\
\hline
\end{tabular}

Определим, к какому концу таблицы, заданная точка $x$ располагается ближе. Так как точка располагается ближе к концу интервала интерполирования, то для нахождения производной воспользуемся второй интерполяционной формулой Ньютона:

$$
\begin{aligned}
f^{\prime}(x) & =\frac{1}{h}\left[\Delta y_{\mathrm{n}-1}+\frac{2 t+1}{2} \cdot \Delta^{2} y_{\mathrm{n}-2}+\frac{3 t^{2}+6 \mathrm{t}+2}{6} \cdot \Delta^{3} y_{\mathrm{n}-3}\right. \\
& \left.+\frac{2 t^{3}+9 t^{2}+11 \mathrm{t}+3}{12} \cdot \Delta^{4} y_{\mathrm{n}-4} \cdots\right]
\end{aligned}
$$

Составим таблицу конечных разностей с помощью таблиц Excel.

\begin{tabular}{|l|r|r|r|r|r|r|}
\hline yi & \multicolumn{1}{|l|}{$\Delta \mathrm{y} 0$} & $\Delta 2 \mathrm{y} 0$ & $\Delta 3 \mathrm{y} 0$ & $\Delta 4 \mathrm{y} 0$ & $\Delta 5 \mathrm{y} 0$ & $\Delta 6 \mathrm{y0}$ \\
\hline y0 & 0,0497 & $-0,0089$ & $-0,0003$ & $-0,0003$ & 0,001 & $-0,0021$ \\
\hline y1 & 0,0408 & $-0,0092$ & $-0,0006$ & 0,0007 & $-0,0011$ & \\
\hline y2 & 0,0316 & $-0,0098$ & $1 \mathrm{E}-04$ & $-0,0004$ & & \\
\hline y3 & 0,0218 & $-0,0097$ & $-0,0003$ & & & \\
\hline y4 & 0,0121 & $-0,01$ & & & & \\
\hline y5 & 0,0021 & & & & & \\
\hline y6 & & & & & & \\
\hline & & & & & & \\
\hline
\end{tabular}

Так как $\mathrm{x}_{0}=1,0, \mathrm{x}=1,59, \mathrm{~h}$ (шаг интерполяции $)=0,1$ и $\mathrm{t}=5,9$ 


$$
\begin{gathered}
f^{\prime}(1,59)=\frac{1}{0,1}\left[0,0021+\frac{2 \cdot 5,9+1}{2} \cdot(-0,01)+\frac{3 \cdot(5,9)^{2}+6 \cdot 5,9+2}{6} \cdot(-0,0003)\right. \\
+\frac{2 \cdot(5,9)^{3}+9 \cdot(5,9)^{2}+11 \cdot(5,9)+3}{12} \cdot(-0,0004)
\end{gathered}
$$

Для подсчета приближенного значения производной также воспользуемся программой Excel.

$$
f^{\prime}(1,59)=-0,953898
$$

Вычислим абсолютную погрешность результата. Учитывая, что

$$
f^{\prime}(x)=-\sin (x)
$$

то $f^{\prime}(1,59)=-0,99982$. Абсолютная погрешность результата будет равна $\Delta=|0,99982-0,953898|=0,04592$

Таким образом, можно сделать вывод, что между производной, найденной по формуле Ньютона и производной, найденной стандартным способом, существует минимальная погрешность.

Мы рассмотрели первую и вторую формулы Ньютона и выяснили, для чего они используются, проиллюстрировав на примерах. Материал, представленный в данной статье, может быть использован в занятиях по математике: здесь содержится не только расширенный материал по дифференцированию функций, но приведены примеры, иллюстрирующие возможность включения обучаемых в процесс формирования навыков работы с MS Excel. Также данная статья может быть рекомендован всем желающим, которые хотят усовершенствовать свои математические знания.

\section{Список литературы}

1. Бахвалов Н.С. Численные методы / Н.С. Бахвалов, Н.П. Жидков, Г.М. Кобельков. М.; СПб.: Лаборатория базовых знаний, 2002. - 632 с.

2. Вержбицкий В.М. Основы численных методов. - М.: Высшая школа, 2002. - 840 с.

3. Лимонникова Е.В. Вычислительная математика. - Северодвинск: Севмашвтуз, 2010. $-36 \mathrm{c}$.

4. Моделирование в электроэнергетике: интерполяционный многочлен в форме Ньютона [Электронный ресурс].- Режим доступа: http://simenergy.ru/math-analysis/digitalprocessing/79-newton-polynomial (дата обращения: 01.11.2020). 
Кораблева Диана Александровна

бакалавр, учитель

МБОУ «Лицей №2 им. Б.А. Слободскова»

г. Тула, Тульская область

\section{ТЕХНОЛОГИИ ДОСТИЖЕНИЯ МЕТАПРЕДМЕТНЫХ РЕЗУЛЬТАТОВ ВО ВНЕКЛАССНОЙ РАБОТЕ ПО МАТЕМАТИКЕ У ПОДРОСТКОВ В УСЛОВИЯХ ДИСТАНЦИОННОГО ОБУЧЕНИЯ}

Аннотация: изменение обучающей среды требует использования таких технологий, которые были бы ориентированы на личность и деятельность учашегося по достижению метапредметных результатов, а также могли бы быть реализованы в условиях дистанционного обучения без потери своей эффективности. Статья посвящена диалоговьм технологиям.

Ключевые слова: метапредметные результаты, внеклассная работа, математика.

Метапредметные результаты - способы деятельности, которые применимы не только в рамках образовательного процесса, но и используются при решении проблем в реальных жизненных условиях; освоенные по результатам изучения одного или нескольких учебных предметов [1].

Одной из отличительных особенностей ФГОС II поколения являются повышенные требования к организации внеурочной деятельности. внеурочная деятельность стала обязательной частью образовательного процесса, которая также призвана обеспечивать результаты освоения ООП.

Системно-деятельностный подход к образовательному процессу предполагает не только разработку и реализацию урока, а также организацию и проведение внеурочных занятий по предмету. Метапредметные результаты обеспечиваются за счет формирования системы УУД, организационных форм, которые обеспечивают интеграцию содержания образования и деятельности обучающегося.

К метапредметным универсальным учебным действиям относят: регулятивные УУД, познавательные УУД, коммуникативные УУД, в основе которых лежит концепция структуры и динамики психологического возраста и теории развития [2]. К регулятивным УУД относятся целеполагание, планирование и организация деятельности, самоконтроль, самооценивание и т. п. К познавательным УУД - исследовательские действия, переработку и структурирование информации, работу с научными понятиями и т. П. Коммуникативные УУД направлены на осуществление межличностного общения. М.М. Поташник и М.В. Левит к метапредметным результатам обучения, кроме УУД (регулятивных, коммуникативных, познавательных), относят межпредметные и надпредметные умения и навыки [3]. Следовательно, в работе вместе должны предусматриваться межпредметные связи и точки соприкосновения различных областей для решения практических задач, творчества. Методология занятий должна быть ориентирована на организацию деятельностного, личностно 
развивающего обучения с учетом различных индивидуальных возможностей ученика [4].

Анализируя опыт работы по организации внеурочной деятельности, мы выяснили, что педагоги зачастую используют во внеурочных занятиях дидактические игры [5], интегрирование внеурочного курса из разных предметов [6], составление авторских программ, сочетающих в себе элементы привычных базовых учебных предметов и уроков искусств [7] и т. д.

Анализ психологических особенностей подростков поколения $\mathrm{Z}$ показал необходимость разработки программы внеурочной деятельности по математике, в которой будут использоваться различные формы работы учащихся в группах: решение интересных качественных и количественных задач во время игры, подготовки и реализации проектной деятельности, а также проведение различных математических конкурсов. Такая форма работы позволит включить в процесс не только интеллектуально одаренных учеников, но и слабо успевающих, которые зачастую с удовольствием ходят с друзьями на всевозможные кружки по предметам, а также данная форма работы может быть успешно реализована в условиях дистанционного обучения.

Как уже отмечалось, современные подростки существуют в системе диалога, а не монолога. На основе анализа литературы [8; 9] можно утверждать, что использование диалога в обучении имеет древние традиции. Диалог является пусковым механизмом мышления человека и основой любого человеческого взаимодействия, в том числе и учебного.

Большое значение для педагогического истолкования диалога, с нашей точки зрения, имеет концепция М.М. Бахтина [10]. Автор утверждает, что истина рождается между людьми, совместно ее ищущими в процессе их диалогового взаимодействия. Согласно данной концепции, учитель может сделать возможным диалогическое общение между учениками группы. Для этого необходимо дать каждому из его участников ощущение внутренней уверенности в себе и своих силах, уверенности в принятии себя другими участниками диалога; создать условия для того, чтобы у каждого возникло желание действовать, желание раскрыть себя для других, и других участников диалога для себя; создать особое пространство взаимодействия, где каждый осознает свою ценность, а также ценность и неповторимость других участников диалога.

Для возникновения диалога необходимо: неоднозначно толковать содержание учебного предмета; ставить перед учащимися задачу, проблему, вопрос; содержание предъявлять с разных позиций; давать возможность ученику представить свою позицию.

Анализ деятельности с разных позиций является еще одним из необходимых педагогических механизмов формирования метапредметных умений учащихся. Работа в парах сменного состава позволяет ученикам занимать позиции то учащегося, то обучающего, а во время рефлексии предполагается анализ деятельности и с «метапозиции». В пространстве учебной деятельности необходимо построить личное пространство ученика, исключающее доминирующее положение учителя как посредника между предметом и учащимся [11].

Актуальным механизмом формирования метапредметных умений учеников является наличие субъект-субъектных отношений между учителем и учащимися. Организация учебной деятельности по принципу

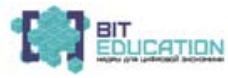


«Каждый - цель, каждый - средство», это значит, что при организации взаимодействия учеников, учеников и учителей должна быть взаимная выгода, т.е. каждый реализует свои цели за счет разных взаимодействий и разных коопераций с остальными участниками учебного процесса, позволяя за счет себя решать свои цели.

Таким образом, изменение обучающей среды требует использования таких технологий, которые были бы ориентированы на личность и деятельность учащегося по достижению метапредметных результатов, а также могли бы быть реализованы в условиях дистанционного обучения без потери своей эффективности, как это происходит с диалоговыми технологиями.

\section{Список литературы}

1. Концепция федеральных государственных стандартов общего образования /под ред. А.М. Кондакова, А.А. Кузнецова - М.: Просвещение, 2008. - 39 с.

2. Формирование универсальных учебных действий в основной школе: от действия к мысли. Система заданий: пособие для учителя / под ред. А.Г. Асмолова. - 4-е изд. - М.: Просвещение, 2014. - 159 с.

3. Поташник М.М. Как помочь учителю в освоении ФГОС: методическое пособие / М.М. Поташник, М.В. Левит. - М.: Педагогическое общество России, 2014. - 320 с.

4. Даутова О.Б. Управление введением ФГОС основного общего образования / О.Б. Даутова, О.Н. Крылова, О.Г. Матина [и др.] - СПб.: КАРО, 2013. - 160 с.

5. Сушенцова Н.В. Формирование метапредметных универсальных учебных действий во внеурочной деятельности по математике в 5-6 классах / Н.В. Сушенцова, Н.И. Мерлина // Вестник ЧГПУ им. И.Я. Яковлева. - 2016. - №1 (89).

6. Глазырина О.Ф. Пути достижения метапредметных результатов при использовании активных форм обучения через интегрированный курс внеурочной деятельности / О.Ф. Глазырина, Т.Ф. Переберина, Ю.А. Гельжинис // Вестник науки и образования. - 2019. - Ч. 1. №1 (55).

7. Афанасьева Т.В. Развитие интеллектуальных способностей младших школьников во внеурочной деятельности в условиях реализации ФГОС НОО // Вестник ЧГПУ им. И.Я. Яковлева. - 2016. - №2 (90).

8. Мамардашвили М.К. Формы и содержания мышления (к критике гегелевского учения о формах познания) / М.К. Мамардашвили. - М.: Высш. шк., 1968.

9. Федотова Е.Л. Педагогическое взаимодействие учителя и учащихся: опыт эмпирического исследования / Е.Л. Федотова. - Иркутск: Изд-во Иркут. гос. пед. ун-та, 2000. - 122 с.

10. Бахтин М.М. Проблемы поэтики Ф.М. Достоевского / М.М. Бахтин. - М.: Художественная литература, $1972 .-470 \mathrm{c}$.

11. Паравян Е.В. Содержание рефлексии учащихся в разновозрастной группе / Е.В. Паравян, Е.А. Пономарева // Коллективный способ обучения: научно-методический журнал. - 2005. - №8. - С. 126-132. 
Мотрюк Екатерина Николаевна канд. техн. наук, заведующая кафедрой ФГБОУ ВО «Ухтинский государственный технический университет» г. Ухта, Республика Коми

\section{ПРЕПОДАВАНИЕ ВЫСШЕЙ МАТЕМАТИКИ В ВУЗЕ ПРИ ДИСТАНЦИОННОМ ОБУЧЕНИИ}

Аннотация: в статье рассмотрены особенности технических, методических составляющих и влияние психотипа личности на процесс обучения.

Ключевые слова: высиая математика, вуз, дистанционное обучение.

В настоящее время очное обучение совмещается с дистанционным (ДО) во всех вузах РФ, что связано с пандемией коронавируса. В этой связи как у преподавателей, так и у студентов возникают различные проблемы как методические, так психологические. Возникает необходимость модифицировать, перестраивать работу. Преподавателю приходится разрабатывать много дидактических и методических материалов, студенту приспосабливаться к режиму работы без непосредственного общения с преподавателем, или с минимизацией такового. На преподавателя в этом случае ложится дополнительная работа по обеспечению эффективного процесса работы, например, созданию и поддержке дистанционного курса. При этом качество процесса обучения, а также полученных при этом знаний и навыков напрямую зависит от степени проработанности электронного курса ДО и от уровня подготовки студента к работе в необходимых программах на персональном компьютере (ПК).

Для прохождения дистанционного обучения высшей математике в нашем вузе и студент, и преподаватель должны хорошо ориентироваться в структуре оболочки Moodle [1], уметь работать с различными типами файлов: pdf, doc, ppt, pps, swf и др. В оболочке Moodle используются при обучении математике следующие элементы: лекции, задания, тесты, форумы, глоссарий.

Рассмотрим основные параметры, касающиеся аудиторной работы при очном обучении и ДО [2]. Например, если на курс отводится 4 зачетных единицы, то это $36 * 4=144$ академических часа и $144 * 1,7=389$ листа формата A4. Далее будем вести расчеты исходя из этих данных. На аудиторную работу отводится $20 \%$ от общего количества академических часов, на самостоятельную - остальные. Один академический час в ДО приравнивается к 2,7 листам формата А 4, 14 шрифтом с одинарным интервалом. Таким образом, для лекций и практик выделено $144 * 0,2 * 2,7=$ 78 листов формата А4. А это главные элементы, способствующие качественному процессу обучения.

Лекция. Ее можно подготовить в виде элемента лекция или файла pdf, doc, ptt и др. Для проверки знаний можно включать в конце лекции контрольные вопросы для проверки освоения материала. Возможно включение аудиофайлов, с проговариванием изучаемых формул. Например, таких как $\mathrm{n} !-\ll н-ф а к т о р и а л »,-\frac{d t}{d x}$ «д т по д х». Можно подготовить видеофайл с 
лекцией, но тут необходима техническая помощь для проведения съемки и время. Опытным путем было выявлено, что для эффективности процесса обучения на видеолекции не должно выделяться более 10-15 минут. Если материала много, сделать блоками, два видеофайла. На все лекции по плану отводится 10 академических часов.

Однако лекции такого формата можно заменить онлайн-занятиями в zoom, jitsi meet, google meet т. д. Здесь опять же возникает проблема времени для подготовки качественной презентации, в частности, по разделам высшей математики не избежать необходимости использования обилия формул и выкладок. В zoom еще можно использовать доску, но мышкой писать не очень удобно. Если демонстрировать wordфайл, писать там, то набивание формул будет затягивать время, и внимание студентов будет теряться. Здесь для лучшего восприятия материала оптимально было бы использовать анимацию, чтобы создать видимость очной лекцией с последовательным фиксированием информации на доске.

Практическое занятие. Данный элемент в оболочке можно ввести как лекцию, только с разбором практических заданий. Отводится тоже 10 академических часов.

При практическом занятии также можно обратиться к zoom, jitsi meet, google meet т. д. Здесь необходима обратная связь. Выход только в том, чтобы дать время для решения задачи или ее части всей группе, после ктонибудь из студентов тут же показывает свой результат на экране для всех (фотографирует и пересылает на ПК, набивать формулы в Worde при демонстрации не эффективно, теряется время и все внимание концентрируется на создании формул), и далее следует сверка результатов, пояснение моментов, на которые стоит обращать внимание и где были, если были, ошибки. Рекомендуются следующие нормативы: для 1 часа лекции по учебному плану в виде презентации - 10 слайдов; 1 час лекции соответствует конспекту 4 страниц А4, кегль 12, на 1 час лекции 1-2 видеопрезентации по 7-9 минут; вопросы для самоконтроля - на 1 час лекции 10-15 вопросов.

Вебинар. Это онлайн-семинар, позволяющий собеседникам, которых может быть много, например, вся группа, показывать различные материалы, файлы, презентации. Можно проводить в определенное время в реальном режиме, но качество связи оставляет желать лучшего. То, что студент решит в тетради и захочет показать, преподавателю с другой стороны экрана может быть плохо видно. Подходит больше для гуманитарных дисциплин.

Стоит обратить внимание на тот момент, что как при проведении лекции, так и практики, у студента должны быть все необходимые технические средства, и он должен уметь ими с легкостью пользоваться. В противном случае психологическое напряжение, вызванное этим не умением, сведет процесс учебы на нет, да еще и будет способствовать возникновению нервозности. Не маловажным является тот момент, что не все имеют необходимые технические средства, в том числе и доступ в интернет. Без этого обучение невозможно. Но это уже не вопрос для рассмотрения в этой статье.

Контрольные мероприятия. На весь курс ДО планируется 43 элемента в системе. С активной обратной связью в курсе должно быть

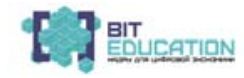


12 интерактивных элемента (элемент задание, проверяется преподавателем), 27 с пассивной интерактивностью (элемент тест, проверяет система). На промежуточный и текущий контроль - 4 элемента. Количество элементов на неделю (семестр длится 17 недель) - 2,5.

Задание. Является активным элементом, с обратной связью. Для уменьшения нагрузки, связанной с проверкой заданий, можно организовать самопроверку.

Tecm. Является пассивным элементом, проверяется системой. Для дисциплины математика для обучения и контроля применимы следующие виды тестовых вопросов: множественный выбор, числовой, вычислимый, на соответствие, альтернативный. Их разнообразие позволяет развивать логическое мышление. Для корректной проверки база вопросов должна содержать примерно 200 вопросов на 1 зачетную единицу.

Если учесть, что элементы контроля (задания, тесты, вопросы) планируются по 30 минут минимум, то это $2,5 * 30$ минут $=75$ минут $=1$ час 15 минут в неделю. Не стоит забывать, что еще студенту надо выполнить контрольную работу в семестр помимо этого. Это только на контрольные мероприятия! Однако при очном обучении этот процесс занимает меньше времени, и контроль усвоения материала легче фиксировать при очных занятиях. Все задания должны соответствовать требованиям ГОС по техническим специальностям. Обычно эффективно проводить тестирование не более часа. Это необходимо для того, чтобы студент не переутомился.

Журнал оценок. Имеется возможность видеть оценки за каждое контрольное задание, сумму баллов, как для студента, так и для преподавателя. Можно анализировать результат и принимать действия по исправлению и своевременной ликвидации долгов.

Форум. В данном элементе могут обсуждаться любые вопросы, как по изучаемой теме, так и по процессу обучения. Это как быстрый обмен текстовыми сообщениями. Вопросы для обсуждения видны всем участникам курса. Чат и форум необходим для текущего контроля работы студентов и разрешения возникших трудностей при выполнении работ.

Преподавателю для создания всех элементов приходится тратить много времени, а в отсутствии достаточного его количества страдает качество. Хочется отметить, что проведение контроля с активной связью для преподавателя превращается в индивидуальный контроль, при большом количестве студентов в группе это очень большая нагрузка.

Большим недостатком ДО является то, что работы, которые выполняет студент, могут быть решены другим человеком, и это можно проверить только при очной встрече, видео-диалоге или вебинаре, при подключении прокторинга (а это дополнительные затраты, поэтому это не везде возможно, подробнее https://ht-lab.ru/knowledge/articles/print.php?f=print\&p= 4455). Это позволяет подтвердить личность кандидата, объективно оценить его знания, исключить шпаргалки и прочие уловки на экзамене.

По опыту работы можно рекомендовать увеличить число аудиторных часов в ДО, так как по расчету на 20 плановых академических часов приходится только 54 листа А 4, и это только 14\%, а не 20\%. Или увеличивать процентное содержание самостоятельной работы студентов. Кстати, на самостоятельную работу предлагается изучение 311 листов формата A4. Необходимо учесть также, чтобы студент тратил в неделю на обучение времени в соответствии с учебными планами. Например, для дисциплины 
в 4 зачетных единицы - не более 4,5 часов в неделю, если обучение длится 32 недели.

Далее обсудим как влияют особенности характера личности студента на процесс и качество обучения при очном и дистанционном формате. Есть студенты, которые хотят учиться; другие учатся из-под палки, их нужно постоянно дергать; третьи считают, что они все знают и так, к ним тоже нужен особый подход. Проблема в том, что при дистанционном формате, даже на онлайн занятии это сделать сложнее, так как индивидуальный подход при очном обучении можно использовать на одном занятии, оценивая сразу всю аудиторию. При ДО необходимо с каждым студентом дискутировать отдельно, либо отвечать на вопросы, либо побуждать выполнять задания, а также помогать находить и исправлять ошибки.

В студенческом возрасте психотип личности может быть еще не уравновешен, однако основа должна уже быть. Особенности темперамента (холерик, флегматик, меланхолик, [3]) определяют такие особенности личности, как работоспособность, сосредоточенность, переключаемость, отвлекаемость внимания, скорость восприятия, запоминания, узнавания, актуализации знаний, скорость мыслительной деятельности и т. д., а также по динамическим особенностям эмоционально-волевой сферы. Возможность прокрутить лекционное или практическое занятие при ДО позволяет компенсировать медленный темп умственной деятельности студентам-интровертам. Однако необходимость соблюдения шаблонов, систематизации, планирования и проверки выполняемой работы, вызывает трудности у студентов-экстравертов, которые тяжело переносят однообразие и монотонность. В этом случае можно дать им не стандартное задание, которое может их заинтересовать. А мотивировать тех, кому не интересно, можно не только хорошей оценкой, но и посредством наглядных, дидактических и технических средств обучения (компьютерные учебные пособия; флэш-анимационные карточки с дозированной помощью, с образцами решения задач (алгоритмами действий); постановка заданий к наглядной информации). В настоящее время возможность изучения материала с прохождением тестов, интересными заданиями и вопросами, по 9000 курсам для ВО и СПО имеется в ЮРАЙТе. Большинство вузов имеет доступ к этой среде, в том числе и УГТУ.

Отметим теперь, что у каждого человека может преобладать тот или иной канал восприятия информации. Выделяют следующие основные типы. Визуалы лучше воспринимают информацию через зрительные представления. Аудиалы лучше воспринимают информацию через слуховые представления. Кинестетики лучше воспринимают информацию через кожные и внутренние ощущения, чувства. Логики (дигиталы, дискреты) - лучше воспринимают информацию через рассуждения, отрываясь от непосредственного ощущения. Понятно, что устный рассказ лучше всего воспринимают аудиалы (таких людей может быть до 10\%). Рисунки, надписи, чертежи и таблицы, а также яркие зрительные образы, переданные в речи - визуалы (до 70-90\%). Кинестетики (до 40\%) лучше воспринимают информацию, ощупывая, обводя контуры, представляя себе внутренние ощущения, делая что-то руками. Логики (по ним нам пока данные не известны) требуют времени на осмысление и опираются на абстрактные знания и понятия. Таким образом, как при очном, так и при дистанционном обучении, необходимо это учитывать и использовать все виды 
представления информации, и ее обработки студентами. Хотя при очном обучении говорить на языке, очевидном, убедительном для собеседника легче, так как имеется более тесный контакт.

Еще одним недостатком дистанционного формата является преобладание сидячего образа жизни, чтение материала с экрана ПК, выполнение различных заданий за компьютером. Чтобы избежать переутомления, необходимо делать гимнастику для глаз, для нормализации мозгового кровообращения, для снятия утомления с плечевого пояса и рук, с туловища и ног, через определенные промежутки времени - медики рекомендуют каждые 45 минут. Не обязательно делать много упражнений, достаточно размяться, хватит 5-7 минут. Комплексы можно найти в свободном доступе в Интернете.

\section{Заключение}

Несмотря на указанные недостатки ДО, данный вид обучения является интересным, особенно для молодых и активных. Это оптимальный вариант в сложившейся в связи с коронавирусом ситуации, необходимостью изоляции для уменьшения вероятности заражения. Перспективы ДО связаны с мобильностью, разнообразием образовательных методик, учитывающих особенности типа обучения, изучаемого предмета, разнообразие психотипов личности, типов восприятия информации, дальнейшим развитием технологических средств.

\section{Список литературы}

1. Андреев А.В. Практика электронного обучения с использованием Moodle / A.В. Андреев, С.В. Андреева, И.Б. Доценко. - Таганрог: Изд-воТТИ ЮФУ, 2008. - 146 с.

2. Методические указания по разработке электронного ресурса. - Ухта: УГТУ, 2011. - 19 с.

3. Аверин В.А. Психология личности. - СПб: Изд-во В.А. Михайлова, 1999. - 89 с.

Пономарева Юлия Андреевна

бакалавр техн. наук, магистрант

ФГБОУ ВО «Набережночелнинский государственный

педагогический университет»

г. Набережные Челны, Республика Татарстан

\section{РОЛЬ ИНФОРМАЦИОННЫХ ТЕХНОЛОГИЙ В ОБУЧЕНИИ МАТЕМАТИКЕ}

Аннотация: в статье рассматривается роль информационных технологий в обучении математике.

Ключевые слова: информационные технологии, информатизация, электронные образовательные ресурсы.

В современном обществе прогрессивно развивается наука семиотика. Данный процесс «семиотизации» общества можно охарактеризовать как появление и формирование многочисленных знаковых систем, благодаря которым образуется многокомпонентное «информационное поле», представляющее собой специфическое информационное окружение человека. Возможности информационных технологий безграничны, поэтому возникает проблема информационно-коммуникативной адаптации человека в обществе. В настоящее время социум осознает, что будущее невозможно без информатизации всех сфер человеческой жизни. 
Поток информации, с которым сталкивается человек каждый день, становится все более мощным. Это приводит к тому, что с каждым годом прогрессирует разрыв между общим количеством научных знаний и той частью, которая усваивается в образовательном учреждении.

Современный учащийся должен уметь приспосабливаться к различным жизненным ситуациям; развивать самостоятельно необходимые предметные знания для решения практических задач; владеть навыками преодоления стереотипов мышления; развивать способность к адаптации в постоянно меняющейся информационной среде; быть гибкой, мобильной, проявляющей проницательность, толерантной, творчески инициативной, конкурентоспособной личностью [5].

По этой причине способы и методы обучения меняются в преподавании существующих знаний так и в обучении поиска, хранения, выбора, качественной обработки информации и ее применения.

Информатизация - это совокупность мер, направленных на обеспечение использования знаний во всех видах школьной деятельности.

Целью современного урока является формирование ярких представлений о предмете и образного мышления в целом. Большие возможности для реализации информатизации заложены именно в использовании компьютера в школе.

В современной системе образования используются самые различные инновационные технологии. Развитие новых информационных технологий в образовании, мотивирует специалистов на разработку новых программных пакетов и приложений, реализующих методологические идеи, связанные с доступом к учебной информации, проверкой правильности полученных результатов, оценкой подготовки и т. д.

Современный специалист должен обладать базовой информационной подготовкой, поскольку увеличивается объем научно-технической информации и образовательное учреждение не в состоянии обеспечить учащихся полным объемом знаний на всю их сознательную жизнь. Следовательно, самым главным в профессиональной компетентности является не информированность ученика, а умение использовать современные технологии для решения возникших проблем в разных сферах деятельности.

Информационные технологии имеют особое значение во всех сферах деятельности человека, особенно в обучении. Благодаря информационным технологиям и интернету, учащиеся могут совместно работать над проектами, а также они получают доступ к информационным ресурсам не только своей школы или вуза, но и к другим источникам в стране и за рубежом.

Специфика компетентного обучения с помощью информационных технологий состоит в том, что учащимися усваивается не информация, предложенная учителем, а прослеживаются этапы возникновения данного знания. В процессе учебной деятельности появляются благоприятные условия для формирования и развития личностных качеств учеников.

Использование информационных технологий помогает учителю наглядно представить необходимые дидактические единицы учебной информации, повысить интерес учащихся к математике, содействовать накоплению учащимися опорных фактов и способов деятельности по образцу.

При использовании информационных технологий в процессе обучения происходит существенное изменение учебного процесса, например:

1) переориентация на развитие воображения и мышления, как основных процессов познания, которые важны для качественного обучения; 
2) формируется эффективная организация самостоятельной познавательной деятельности учащихся;

3) появляется способность к творчеству, сотрудничеству и самосовершенствованию.

При использовании информационных технологий по-прежнему сохраняются все основные этапы урока. В контексте традиционного урока электронные версии некоторой части учебного материала делают процесс получения знаний более полным и эффективным.

На уроках математики посредством компьютера можно решить проблему отсутствия подвижной наглядности, например, когда дети под руководством учителя на экране монитора анализируют взаимоотношения множеств, сравнивают способом наложения геометрические фигуры.

В старших классах, например, можно обучить основам прикладных пакетов (MathLab, Maxima) для наглядного представления функций, их графиков и обучить посредством этих программ началу математического анализа.

Компьютер - это также мощнейшее средство для творчества детей. Экран притягивает внимание, которого порой сложно добиться при фронтальной работе с классом. На экране можно быстро преобразовать деформированный текст, превратив отдельные предложения в связный текст. Но для того, чтобы учащиеся могли использовать компьютер как помощник, обучить их основам работы с компьютером, интернетом и прикладными пакетами программ. При помощи современных информационных технологий, например, электронных образовательных ресурсов и эффективных методов обучения можно заинтересовать учащихся и облегчить усвоение материала.

Применение современных информационных технологий позволяет заменить многие традиционные средства обучения. Во многих случаях такая замена оказывается довольно-таки действенной, потому как она помогает поддерживать и стимулировать у учащихся интерес к изучаемому предмету. Информационные технологии создают возможности для учителя сочетать разнообразные средства, способствующие более глубокому и осознанному усвоению изучаемого материала, экономят время урока, позволяют организовать образовательный процесс.

\section{Список литературы}

1. Барышникова Г.Б. Психолого-педагогические теории и технологии начального образования / Г.Б. Барышникова. - Ярославль: ЯГПУ, 2009.

2. Педагогический энциклопедический словарь / гл. ред. Б.М. Бим-Бад. - М.: Большая рос. энцикл., 2002. $-528 \mathrm{c}$.

3. Информационные и дистанционные технологии в образовании: путь в XXI веке. - М., 1999.

4. Леонтьев А.Н. Деятельность, сознание, личность. - М.: Политиздат, 1975.

5. Молоков Ю.Г. Актуальные вопросы информатизации образования / Ю.Г. Молоков, А.В. Молокова // Образовательные технологии: Сб. науч. ст. Вып. 1 / под ред. И.М. Бобко. Новосибирск: СИОТ РАО, 1997. - С. 77-81. 
Попова Татьяна Александровна

студентка

ФГБОУ ВО «Мордовский государственный педагогический институт им. М.Е. Евсевьева» г. Саранск, Республика Мордовия

\section{РОЛЬ МЕТОДОВ МАТЕМАТИКИ В ОБУЧЕНИИ ПРОГРАММИРОВАНИЮ}

Аннотация: в статье описаны условия для успешного решения задач программирования. Одним из них является умение организовать конвергенциию методы предметных дисциилин. Автором рассмотрены некоторые методы математики, которые можно внедрить в прочесс обучения программированию, и определена их роль.

Ключевые слова: программирование, алгоритмическое мылиление, междисииплинарность, конвергенция, численные методы, математическое моделирование, вычислительный эксперимент, математическая логика, математическая статистика, математический анализ.

Помимо наличия у учащихся системы знаний, умений и навыков, приобретенных ими в процессе изучения технологии программирования, успешный результат достигается за счет умения переносить знаний сформированных на одном предмете в другой, а также комплексное использование фундаментальных знаний различных предметов.

Задачи междисциплинарного характера способствуют развитию у учащихся умений моделировать процессы, представленные в задаче [2, с. 65]. При реализации междисциплинарных связей математики и информатики у учащихся формируются умения составлять математическую модель того или иного процесса, а умения реализовать их на компьютере говорит о развитие алгоритмических способностей, наличие которых просто необходимо в условиях современного мира.

Необходимым условием решения задач по программированию является: развитое, у учащихся, алгоритмическое мышление, умение исследовать различные процессы, обычно начинающиеся с их моделирования, т. е. отражения реального процесса через математические соотношения [1, с. 51].

Учебные задачи по программированию включают в себя практическую и прикладную направленность, что обуславливает целесообразность внедрение методов других дисциплин при обучении данной дисциплине. Специфические особенности математики схожие с особенностями программирования подталкивают на конвергенцию их методов [3, с. 123].

Рассмотрим методы математики и определим роль их использования при обучении программированию.

Математические методы подразделяются на: численные методы, метод математического моделирования, метод вычислительного эксперимента, методы математической логики, методы математической статистики, функционально-графический метод [4, с. 20].

Численные или вычислительные методы - методы решения математических задач в численном виде. Численные методы считают методами приближённого решения математических задач, сводящиеся к выполнению конечного числа элементарных, как правило, арифметических, операций над числами. 
К задачам вычислительной математики относят: решение линейных и нелинейных, дифференциальных, интегральных уравнений и их систем; нахождение собственных значений и векторов матрицы; задачи аппроксимации, интерполяции, экстраполяции.

Численные методы широко используются в различных специализированных математических пакетах и системах программирования как инструмента решения прикладных задач [4, с. 24]. В задачах программирования часто требуется выполнить огромное количество действий, более того, есть задачи, где без достаточно сложных численных методов не удалось бы получить ответа. Таким образом, численные методы - это не только альтернатива аналитическим подходам при решении задач программирования, но и в подавляющем большинстве случаев - единственный реализуемый подход решения этих задач.

Математическое моделирование - это метод исследования явлений, процессов или систем объектов, путем построения их математических моделей, исследование этих моделей, позволяющее получить, с некоторым приближением, характеристики рассматриваемого реального объекта.

Математическая модель - это приближенное описание какого-либо класса явлений или объектов реального мира на языке математики.

Основные этапы математического моделирования: 1) построение модели; 2) решение математической задачи, к которой приводит модель; 3) интерпретация полученных следствий из математической модели; 4) проверка адекватности модели; 5) модификация модели. То есть анализ математических моделей включает в себя изучение постановки задачи, выбор модели, анализ и обработку входной информации, численное решение математических задач, возникающих в связи с исследованием модели, анализ результатов вычислений, и, наконец, вопросы, связанные с реализацией полученных результатов.

Для наиболее точных и сложных моделей основными методами решения являются численные методы, требующие проведения большого объема необходимых вычислений, для этого целесообразно использовать систему программирования. Часто в решениях задач по программированию для количественного и даже качественного результата необходимо использовать формальное описание изучаемого явления, «перевести» все существующие сведения о нем на язык математики в виде уравнений, тождеств, неравенств, т. е. составить математическую модель. Необходимо помнить, что модель должна строиться для решения определенного класса задач или конкретной задачи исследования системы.

Bычислительный эксперимент представляет собой исследование физической проблемы средствами математики. По сути, вычислительный эксперимент, - это эксперимент над математической моделью объекта на ЭВМ, который состоит в том, что по одним параметрам модели вычисляются другие её параметры и на этой основе делаются выводы о свойствах явления, описываемого математической моделью.

Он включает в себя следующие этапы: постановка задачи; разработка вычислительного алгоритма; создание программы, способной реализовать созданный вычислительный алгоритм; проведение необходимых расчетов на электронно-вычислительных машинах; обработка полученных результатов, анализ исследования, формирование выводов. Таким образом, метод вычислительного эксперимента реализуется в языках программирования [3, с. 65].

Математическая логика - это метод формирования доказательств и опровержения различных положений. Сейчас она широко используется в 
различных языках программирования, позволяя делать программы максимально удобными и нересурсозатратными.

Математическая статистика включает в себя математические методы систематизации и использования статистических данных для научных и практических выводов. В программировании она играет огромную роль: благодаря статистике создаются динамические программы.

Понимание принципов математического анализа помогает в решении сложных задач в программировании.

Функционально-графический метод основан на геометрической интерпретации задачи и применяется в основном при решении задач двумерного пространства. Данный метод позволяет геометрически подтвердить справедливость теорем линейного программирования.

Таким образом, мы определили роль методов математики в обучении программированию. Использование методов математики в обучении программированию повышает междисциплинарность, а это отвечает современным требованиям к обучению предметных дисциплин и образованию в целом [2, с. 67].

\section{Список литературы}

1. Радаева Т.А. Обучение программированию в системах с интегрированной средой разработки / Т.А. Радаева // Актуальные вопросы теории и практики обучения информатике в школе: сборник научно-методических трудов студентов и молодых ученых по материалам Всероссийской молодежной научной интернет-конференции «Информационное общество и молодежь» / редкол.: А.А. Зубрилин, М.А. Фролова; Мордов. гос. пед. ин-т. - Саранск, 2017. - С. 48-52.

2. Радаева Т.А. Конвергентное обучение - новый этап современного образования / T.А. Радаева // Сетевое взаимодействие как условие формирования нового качества профессионального образования: сборник материалов IV Всерос. науч.-практ. конф. - Борисоглебск, 2019. - 235 с.

3. Сафонов В.И. Методические цели использования методов информатики и ИКТ в изучении математики / В.И. Сафонов // Гуманитарные науки и образование. - 2014. - №1 (17). C. 64-67.

4. Сафонов В.И. Реализация междисциплинарности в подготовке педагогических кадров / В.И. Сафонов // Актуальные вопросы организации научно-методического обеспечения университетского образования: сборник трудов Междунар. научно-практической интернетконференции. - Минск: Белорусский государственный университет, 2017. - С. 120-124.

5. Сафонов В.И. Реализация методов математики и информатики с использованием возможностей специализированных программных продуктов / В.И. Сафонов // Учебный эксперимент в образовании. - 2016. - №3 (79) - С. 19-26. 
Шакирова Регина Валерьевна

бакалавр техн. наук, преподаватель ГАПОУ «Набережночелнинский педагогический колледж» г. Набережные Челны, Республика Татарстан

\section{ЭЛЕКТРОННЫЕ ОБРАЗОВАТЕЛЬНЫЕ РЕСУРСЫ КАК СРЕДСТВО ОБУЧЕНИЯ ДИСКРЕТНОЙ МАТЕМАТИКЕ}

Аннотация: статья обосновывает актуальность использования информационных технологий в процессе обучения дискретной математике и степень разработанности проблемы в научных исследованиях. Автор описывает важность владения методами дискретной математики. В работе приведена структура электронного образовательного ресурса.

Ключевые слова: дискретная математика, информационные технологии, электронный образовательный ресурс, учебный проиесс.

В настоящее время дискретная математика является интенсивно развивающимся разделом математики. Это связано с повсеместным распространением компьютерных систем, языком описания которых она является. Кроме того, дискретная математика является теоретической базой информатики, которая всё глубже и глубже проникает не только в науку и технику, но и в повседневную жизнь.

Стало привычным соглашаться, что преподавание дискретной математики представляет собой сложную и междисциплинарную деятельность. Большинство понятий математики преподаются через абстрактный язык. В учебной программе недостаточно анализа этих фундаментальных понятий. Обычно они даются без детального анализа, как если бы они были очевидны. Понятие доказательства является чем-то очень нечетким для большинства студентов, и даже необходимость строгого обоснования утверждения не так ясна для большинства из них. Тем не менее, все они будут писать сложные программы, и весьма важно, чтобы они понимали основные вопросы корректности программ.

Умение логически понимать и решать задачу, которая будет поставлена перед любым программистом (независимо от языка программирования) является основополагающей, без логики невозможно полноценно и правильно решить задачу. Корректной можно считать только ту программу, которая исполняет функции, указанные в её технической спецификации, однако результат на уровне тестирования может кардинально отличаться в условиях реальной работы, поэтому необходимо проверить корректность алгоритма: нужно проверить изменения переменных программы, которые оно используется на всех этапах работы алгоритма (до, во время работы и после). Базовые математические знания должны быть частью научной культуры студента, изучающего компьютерные науки.

Электронный образовательный ресурс является универсальной и необходимой формой в процессе обучения [3]. Электронный образовательный ресурс (ЭОР) - это совокупность программных средств, информационных, технических, интерактивных материалов, полнотекстовых электронных изданий, включая аудио и видеоматериалы, иллюстративные материалы и каталоги электронных библиотек, размещенные на компьютерных носителях и в сети Интернет [2]. Электронный ресурс на деле осуществляет индивидуальный подход к каждому ученику. Основное отличие электронного образовательного ресурса от традиционных печатных 
изданий заключается в обязательном наличии интерактивного взаимодействия между учеником и компьютером. При помощи него каждый обучающийся может заниматься самостоятельно. Пропустив занятие, ученик сможет сам изучить ту или иную тему при помощи электронного учебника [4]. Многоуровневость позволяет изучать предмет с различной степенью глубины. И наконец, использование нетрадиционных форм подачу и контроля материала оживляет и создает благоприятную обстановку в учебной группе.

Проблеме компьютеризации математических курсов посвящены работы Е.Ю. Жоховой, Р.А. Майера, В.Р. Майера, Д.В. Майера и др. В работах этих авторов рассмотрены вопросы применения компьютерных технологий в курсах алгебры и геометрии.

Использование математических пакетов в процессе преподавания теории вероятностей и математической статистики посвящены работы А.М. Андронова, А.В. Ванюрина, Л.Я. Гринглаз, Е.А. Копытова, С.А. Самсоновой, М.А. Суворовой.

Значительно меньше исследований, посвященных проблеме использования информационных технологий в курсе дискретной математики. А.С. Алфимова в своей работе исследовала аспекты использования информационных технологий в рамках курса дискретной математики в школе. В данных исследованиях показана эффективность применения информационных технологий в организации самостоятельной работы учащихся, в обеспечение дифференциации обучения и повышении его качества [1].

Для повышения эффективности обучения студентов среднего профессионального образования возникает необходимость в разработке электронного образовательного ресурса «Дискретная математика».

Электронный образовательный ресурс предназначен для наглядной демонстрации объяснения нового материала, закрепления пройденного, обобщения и систематизации знаний. В каждом разделе имеется теоретический материал, примеры решения задач и практические задания.

Во вкладке Учебник предложен теоретический материал по всем темам разделов дискретной математики с примерами решения задач. Учебник состоит из разделов:

- теории множеств и комбинаторика;

- теории графов;

- элементов математической логики;

- логику предикатов;

- теории автоматов.

Задачник включает в себя комплекс задач по всем темам дискретной математики, имеются задачи для самостоятельного решения и задачи повышенной сложности.

Во вкладке Демонстрации также предложен теоретический материал по каждой лекции дискретной математики в виде демонстрационной программы или видеоматериала.

Контроль знаний содержит тестовые задания по разделам.

Ниже представлена схема электронного ресурса по дискретной математике. 


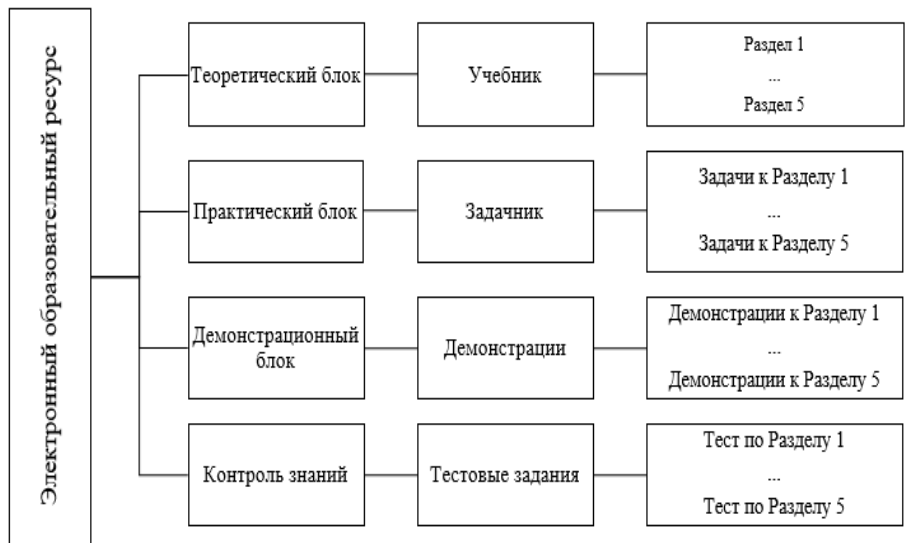

Рис. 1. Структура электронного образовательного ресурса

Электронный образовательный ресурс «Дискретная математика» обеспечивает не только освоение базовых понятий и конструкций дискретной математики, но и способствует усилению самостоятельности, формированию и развитию профессиональной мотивации, контролю и самоконтролю учебной деятельности обучающихся.

\section{Список литературы}

1. Алфимова А.С. Методика преподавания элективного курса «Элементы дискретной математики» с использованием информационно-коммуникационных технологий для учащихся естественно-математического профиля обучения: дис. канд. пед. наук. - Махачкала, 2009. $-158 \mathrm{c}$.

2. Исупова Н.И. Использование электронных образовательных ресурсов для реализации активных и интерактивных форм и методов обучения / Н.И. Исупова, Т. Н. Суворова // Концепт. - 2014. - Т. 26. - С. 136-140.

3. Урбанович Ю.П. Современные электронные образовательные ресурсы в образовательной практике / Ю.П. Урбанович, Н.В. Ломовцева // Новые информационные технологии в образовании: материалы 8-й Междунар. науч.-практ. конф. / Рос. гос. проф.-пед. ун-т. - Екатеринбург, 2015. - С. 92-95.

4. Дистанционное обучение в школьном курсе информатике [Электронный ресурс]. Режим доступа: http://www.bestreferat.ru (дата обращения: 03.06.2020).

5. Создание электронного обучающего комплекса [Электронный ресурс]. - Режим доступа: http://www.bestreferat.ru (дата обращения: 02.06.2020). 


\title{
ЛУЧШИЕ ПРАКТИКИ «ВЫЗОВ ЦИФРОЙ» ПО ПРЕДМЕТНОЙ ОБЛАСТИ «ИНФОРМАТИКА»
}

\author{
Анетова Айжан Жакановна \\ магистр техн. наук, старший преподаватель \\ Тулегулов Амандос Дабысович \\ канд. физ.-мат. наук, ассоциированный профессор
}

Ешпанов Владимир Сарсембаевич д-р ист. наук, профессор

Казахский университет технологии и бизнеса г. Нур-Султан, Республика Казахстан

\section{РАЗВИТИЕ ОБУЧАЮЩИХСЯ В ПРОЦЕССЕ РАЗРАБОТКИ ТВОРЧЕСКИХ КОМПЫЮТЕРНЫХ ПРОЕКТОВ В УСЛОВИЯХ ДОПОЛНИТЕЛЬНОГО ОБРАЗОВАНИЯ НА ФАКУЛЬТАТИВНЫХ ЗАНЯТИЯХ ПО ПРЕДМЕТУ «ИНФОРМАТИКА»}

Аннотация: в статье изучен образовательный процесс современной школь, строящийся с целью формирования у обучающиххя креативности $u$ положительной мотивации восхождения к научному исследованию, умения добиваться конечного результата, а также развития действенных, жизненно значимых знаний, необходимых для развития их личности. В работе обосновано, что данные качества ичелесообразно развивать в процессе осуществления метода разработки творческих компьютерных проектов в условиях дополнительного образования на факультативных занятиях по предмету «Информатика».

Ключевые слова: общеобразовательная школа, обучающиеся, прочеес развития личности, компьютерные проектьл, разработка творческих проектов, факультативные занятия, предмет «Информатика».

Социально-экономические преобразования в обществе диктуют необходимость формирования личности, обладающей способностью эффективно и нестандартно решать жизненные проблемы. В этой связи перед общеобразовательной школой встает важная задача - создание благоприятных условий для развития личности школьника, что, в свою очередь, требует оптимизации учебного процесса с учетом индивидуально-психологических особенностей учащихся, создания условий для раскрытия и развития потенциальных возможностей и творческих способностей каждого из них, где творцом способов учения является сам ученик, а также формирование действенных, жизненно значимых знаний, необходимых для развития его личности, и т. д.

В Законе «Об образовании» в качестве высшей цели образования определено становление саморазвивающейся и самоопределяющейся личности, способной к открытому творческому взаимодействию с окружающей

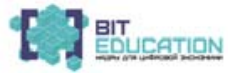


средой и обществом. Одним из приоритетных направлений педагогической науки в настоящее время является поиск новых путей развития детей и их креативности в процессе образования.

На уроках информатики в ходе деятельности по разработке творческих компьютерных проектов можно способствовать формированию положительной мотивации и креативности обучающихся, восхождению их к научному исследованию, обучению умению добиваться конечного результата в любой сфере деятельности. Разработка творческих компьютерных проектов - это процесс и результат разработки программного обеспечения для образования детей и подростков на основе изучения новых информационных технологий. При этом осуществляется личностно-ориентированный подход к деятельности, который предполагает гуманистические отношения, демократизацию и наличие таких технологий, в которых взрослый и ребенок объединены в совместной деятельности [1, с. 36].

Проблема личностно-ориентированного образования с учетом особенностей каждого ученика для раскрытия и развития его потенциальных возможностей успешно может быть решена в процессе разработки творческих компьютерных проектов. Метод творческих компьютерных проектов, применяемый нами в дополнительном образовании (факультативные занятия по предмету «Информатика»), крайне мало исследован, поэтому нет определенных требований к проектам такого типа. Несмотря на то, что в настоящее время идет увлечение презентациями, недостаточно внимания уделяется назначению, цели и уровню их разработки как по содержанию, так и по форме. Поэтому необходимо разработать требования к творческому компьютерному проекту школьника.

В ходе осуществления данной деятельности были определены следующие задачи:

1) разработать рекомендации для школьников, учителей общеобразовательных школ и педагогов дополнительного образования детей и молодежи по организации практической деятельности при создании творческих компьютерных проектов;

2) определить требования к оценке качества компьютерных творческих проектов.

Методологическую базу исследования составляют:

- гуманистический подход, ориентированный на уважительное отношение к ребенку, на выявление и развитие индивидуальных способностей школьника;

- личностно-деятельностный подход, основанный на создании педагогических условий для успешного развития личности школьника в практической деятельности;

- системный и синергетический подходы, предусматривающие исследование проблемы в условиях целостного педагогического процесса.

Важное значение для исследования имеют труды ученых, занимающихся проблемами самореализации личности (Н.Л. Кулик, В.И. Муляр, Г.К. Чернявская и др.). Изучая психолого-педагогические аспекты воспитания личности, мы опираемся на теории возрастных особенностей школьников, раскрытых в трудах Л.И. Божович, Л.С. Выготского, В.В. Давыдова, Д.И. Фельдштейна и др. Проблемы развития человеческой личности в процессе разнообразной деятельности, условия развития 
и саморазвития личности раскрыты в работах Б.Г. Ананьева, Л.С. Выготского, Б.С. Гершунского, В.А. Петровского, С.Л. Рубинштейна и др.

В процессе организации деятельности по разработке творческих компьютерных проектов предполагается использование комплекса методов взаимодополняющих друг друга, как теоретический анализ философской и психолого-педагогической литературы, изучение программно-методических документов; педагогический эксперимент, анкетирование, тестирование, метод экспертных оценок, наблюдение, беседа; обобщение авторского педагогического опыта практической деятельности по изучаемой проблеме; качественный и количественный анализ результатов предметно-практической деятельности школьников [2, с. 55].

Общий план организации деятельности по разработке творческих компьютерных проектов включает в себя несколько этапов (таблица 1).

Таблица 1

План организации деятельности по разработке творческих компьютерных проектов

\begin{tabular}{|c|c|}
\hline Этап & $\begin{array}{c}\text { Деятельность, организуемая на этапах по разработке } \\
\text { творческих компьютерных проектов }\end{array}$ \\
\hline \multirow[t]{2}{*}{1} & $\begin{array}{l}\text { Изучение особенностей интересов и склонностей школьников в } \\
\text { научно-технической области, уровня их развития и } \\
\text { профессиональной ориентации }\end{array}$ \\
\hline & Обработка результатов исследования \\
\hline 2 & $\begin{array}{l}\text { Анализ современного опыта общеобразовательной школы, } \\
\text { дополнительного образования детей и подростков, направленного на } \\
\text { становление личности школьника и его развитие в процессе } \\
\text { разработки компьютерных творческих проектов }\end{array}$ \\
\hline \multirow[t]{2}{*}{3} & $\begin{array}{l}\text { Разработка и издание программы «Мой творческий компьютерный } \\
\text { проект», способствующей успешному развитию личности школьника } \\
\text { и профессиональной ориентации }\end{array}$ \\
\hline & $\begin{array}{l}\text { Апробация программы «Мой творческий компьютерный проект» в } \\
\text { общеобразовательных школах и учреждениях дополнительного } \\
\text { образования }\end{array}$ \\
\hline \multirow[t]{2}{*}{4} & $\begin{array}{l}\text { Проведение научно-практического семинара «Новые педагогические } \\
\text { технологии как средство развития личности школьника» }\end{array}$ \\
\hline & $\begin{array}{l}\text { Разработка методических рекомендаций для школьников, учителей } \\
\text { общеобразовательных школ и педагогов дополнительного } \\
\text { образования по организации деятельности при создании и оценке } \\
\text { компьютерных творческих проектов }\end{array}$ \\
\hline 5 & $\begin{array}{l}\text { Подготовка и публикация научных статей в российских научных } \\
\text { журналах и других источниках педагогической области }\end{array}$ \\
\hline
\end{tabular}

В ходе проведения данной деятельности выявлены достаточные педагогические условия эффективности развития личности в процессе разработки творческих компьютерных проектов, как создание ситуации успеха, организация работы с компьютерными творческими проектами, восхождение к научно-исследовательской деятельности [3, с. 29].

Ожидаемыми результатами деятельности по разработке творческих компьютерных проектов является: 1) повышение уровня развития личности школьника в процессе разработки творческих компьютерных 
проектов; 2) мой творческий компьютерный проект: авторская программа; 3) методические рекомендации для школьников, учителей общеобразовательных школ и педагогов дополнительного образования по организации деятельности при создании и оценке компьютерных творческих проектов и др. [4, с. 118$]$.

Таким образом, с целью оптимизации учебного процесса, создания условий для творческих способностей каждого учащегося целесообразной является организация деятельности по разработке творческих компьютерных проектов в условиях дополнительного образования по предмету «Информатика».

\section{Список литературь}

1. Байбородова Л.В. Проектная деятельность школьников в разновозрастных группах: пособие для учителей общеобразовательных организаций / Л.В. Байбородова, Л.Н. Серебренников. - М.: Просвещение, 2013. - 175 с.

2. Гончарова О.В. Использование идей аэрокосмического программирования в работе с трудными подростками / О.В. Гончарова // Социально-педагогические аспекты работы с неадаптированными подростками: сб. мат. межвузовского научного семинара (25 декабря 2003 года, Вологда). - Вологда. 2004. - С. 54-58.

3. Гончарова О.В. Звездный мир: методические материалы / О.В. Гончарова, Э.В. Зауторова. - Вологда, 2005. - 40 с.

4. Джонсонс Дж.К. Методы проектирования / Дж.К. Джонсонс. - М., 1986. - 326 с.

Бахматова Светлана Владимировна канд. физ.-мат. наук, учитель ГБОУ СОШ №617 Приморского района Санкт-Петербурга г. Санкт-Петербург

Иванова Ираида Павловна канд. пед. наук, заведующая кафедрой ФГБОУ ВО «Чувашский государственный педагогический университет им. И.Я. Яковлева»

г. Чебоксары, Чувашская Республика

\section{УРОКИ ИНФОРМАТИКИ КАК СРЕДСТВО РАЗВИТИЯ ИНФОРМАЦИОННОЙ КУЛЬТУРЫ}

Аннотация: в статье раскрываются возможности уроков информаичи в развитии информачионной культуры. Авторами приведень данные психодиагностики, раскрыты приемы и методы развития информащионной культуры.

Ключевые слова: информация, информационная культура, информационная грамотность, информационная компетентность, информационно-образовательная среда.

XXI век - век информационных технологий, и невозможно представить жизнь без гаджетов. Быстрыми темпами идет развитие технических средств. Актуальной становится проблема развития информационной культуры детей. На сегодняшний день налицо то, что молодые люди быстро осваивают технические новинки, их возможности, но в то же время, получая большой поток информации, не умеют его анализировать,

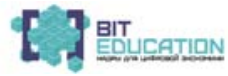


обрабатывать, систематизировать. Как отмечают психологи, бессистемная информация повышает тревожность детей, нарушает эмоциональную стабильность.

Фразу «Кто владеет информацией, тот владеет миром» ввели в оборот представители богатейшей династии Ротшильдов, эта мысль и на сегодняшний весьма актуальна. В наш век информация - это одна из самых важных ценностей, особенно, если она достоверная, востребована способность человека обрабатывать информацию.

Уроки информатики призваны помочь школьникам помочь овладеть навыками обобщения и систематизации специфических знаний, полученные в разных областях и на этой основе сформировать целостное представление о способах и методах работы с информацией, сформировать информационную культуру.

Информационная культура личности - одна из составляющих общей культуры человека; совокупность информационного мировоззрения и системы знаний и умений, которая обеспечивает целенаправленную самостоятельную деятельность по оптимальному удовлетворению индивидуальных информационных потребностей с использованием как традиционных, так и новых информационных технологий в ходе учебной, научнопознавательной и иных видов деятельности.

Критериями информационной культуры человека являются:

- адекватное формулирование своей потребности в информации;

- эффективное и рациональное осуществление поиска нужной информации, находящихся в информационных ресурсах;

- переработка информации и создание качественно новой;

- вести индивидуальные информационно-поисковые системы;

- адекватный отбор и оценивание информации;

- способность к информационному общению;

- компьютерная грамотность.

Элементами информационной культуры являются информационная компетентность и информационная грамотность, которые, несомненно, формируются на уроках информатики.

Информационная компетентность - это способность использовать информационные и коммуникационные технологии для доступа к информации, для ее поиска, организации, обработки, оценки, а также для продуцирования и передачи/распространения, которая достаточна для того, чтобы успешно жить и трудиться в условиях информационного общества. Информационная компетентность проходит три уровня развития:

- пропедевтический уровень (понимание, владение основными понятиями);

- базовый уровень (применение по образцу, выполнение задач по образцу);

- профильный уровень (творческое применение, выполнение заданий, для которых надо продемонстрировать нестандартное решение).

В состав общей информационной компетентности входят следующие блоки: информационный, блок компьютерной и информационной техники, блок операционной системы, блок прикладных программ.

Информационный блок характеризуется:

- поиском информации в различных источниках; использование различных ресурсов (книг, журналов, электронных пособий, Интернета) для нахождения нужной информации; 
- представлением информации в структурированном виде, с использованием таблиц, схем, диаграмм и др. способов;

- выбором способов доведения информации до пользователя с учетом возможностей современной техники.

Блок компьютерной и информационной техники: объяснение структуры современного ПК и обоснование назначения его основных устройств; выбор компьютерной и информационной техники для адекватного решения задач; обоснование способов взаимодействия компьютеров с другой техникой, служащей для сбора, хранения, обработки и передачи информации.

Блок операционной системы: настройка пользовательского интерфейса Windows; работа с файлами; знание основных команд; использование стандартных программ Windows.

Блок прикладных программ: создание и редактирование текстов с рисунками, таблицами, формулами, графиками в редакторе MS Word; построение диаграмм и графиков с помощью MS Excel; поиск информации в Интернете с использованием различных поисковых систем; создание и разработка веб-сайтов, используя редактор визуального веб-конструирования; создание и обработка баз данных.

Информационная грамотность - это набор умений и навыков, позволяющий находить информацию, критически ее оценивать, выбирать нужную информацию, использовать ее, создавать новую информацию и обмениваться информацией.

Она включает:

- стройную, логически связанную, преемственную систему знаний информационных технологий, в том числе компьютерных;

- умения и навыки любой деятельности, связанной с информацией;

- умения и навыки планирования своей деятельности, проектирования и построения информационных моделей;

- дисциплину общения и структурирования сообщений;

- использование современных технических средств жизни.

Также в структуре информационной культуры необходимо наличие у личности осознанной мотивации, которая включает удовлетворение своих информационных потребностей на базе знаний ИКТ; повышение своего общекультурного, общеобразовательного и профессионального кругозора; развитие умений и навыков информационной деятельности и информационного общения на основе использования информационных и телекоммуникационных технологий, в том числе компьютерных; определенный стиль мышления, главной характеристикой которого являются самостоятельность и креативность.

Повышению информационной культуры обучающихся способствует систематическое выполнение заданий на преобразование форм представления информации. Способность создавать собственный информационный продукт на основе самостоятельно найденной, критически оцененной и преобразованной информации является важнейшим свойством творческой личности, развитие которой является первостепенной задачей современной системы образования.

Следовательно, можно говорить о том, что между становлением творческой личности и формированием информационной культуры личности существует тесная связь. Она проявляется в том, что повышение 
продуктивности любого вида интеллектуального труда, сущность которого состоит в работе с информацией (ее анализе, сопоставлении, сравнении, классификации и обобщении), невозможно без соответствующего уровня информационной культуры личности. Без новой информации невозможно развитие воображения, рождение новых образов, развитие творческого мышления, интуиции. Но все это требует от творческой личности не только определенных психофизических качеств, но и специальных знаний, умений, навыков, опыта, системы взглядов в сфере работы с информацией и информационными технологиями, то есть с тем, что составляет сущность информационной культуры личности.

Учебная дисциплина информатика обладает огромными возможностями для формирования информационной культуры, так как само понятие «информация» является ключевым по отношению ко всему курсу информатики и информационных технологий.

Когда с учащимися 6 классов провели исследование, с целью выявления как они понимают «информационную культуру», для чего нужен компьютер, из каких источников получают информацию. Результаты данного опроса показали, лишь 14\% (4 ученика) знают определение термина «информационная культура», 76\% (22 ученика) считают, что информация играет важную роль в жизни человека, говоря об источниках информации, ученики отметили телевидение, компьютер, интернет. Многие ученики наличие компьютера дома считают обязательным 89\% (27 учеников), но лишь 28\% (5 учеников) хотели бы использовать компьютер для учебы.

Полученные результаты свидетельствуют о том, что нужна системная работа в формировании информационной культуры. С этой целью необходима работа по формированию умения поиска данных в различных источниках, в развитии способности использования в своей деятельности компьютерных технологий; в овладении основами аналитической переработки информации. Итак, ученик должен овладеть практическими способами работы с различной информацией.

Информационная культура формируется постепенно, это долгий процесс, где все участники должны приложить максимум усилий. Информационная культура формируется на каждом уроке, начиная с 5 по 11 класс. Вначале дети учатся искать и отбирать информацию, овладевают навыками правильной обработки графической и текстовой информации.

На уроках информатики обучающиеся учатся избирательно отбирать информацию, на уроках закладываются основы правильной отработки графической и текстовой информации. Уроки информатики способствуют формированию у учащихся умения измерять и на профессиональном уровне обрабатывать информацию: оформление рефератов с соблюдением всех требований, докладов, обработка графических файлов, создание документа любой сложности в электронном виде, работа с большими данными.

При подготовке к урокам учитель информатики использует электронные ресурсы учебного назначения: мультимедийные курсы; презентации к урокам; логические игры; тестовые работы; ресурсы Интернет; электронные энциклопедии.

Составляющими информационно-образовательной среды являются учебник, который обеспечивает выход на другие образовательные ресурсы, призванные помочь учащимся «добирать» необходимую информацию, представленную в разных формах в других компонентах учебно-методического комплекта. Электронное приложение к учебнику, где 
возможно расширение информационного поля путем вовлечения в учебный процесс медиаресурсы, способствующие развитию познавательной активности учащихся. Также рабочая тетрадь, позволяющая учащимся формировать и закреплять полученные знания и умения. Важным составляющим является сайты интернет-поддержки, это среда, где сотрудничают учащиеся, учителя, родители, учащиеся могут получать информацию для самообразования.

Таким образом, развитию информационной культуры в учебной деятельности способствует использование информационно-поисковых систем, систематизация информации по заданным признакам, извлечение данных и представление их в табличной форме, составление плана информационного сообщения, выбор формы его изложения, видоизменение формы, знаковой системы, носителя информации, установление ассоциативных и практических связей между информационными сообщениями.

Эффективными методом формирования элементов информационной культуры является проблемный метод, который формирует умение ставить перед собой проблему, сравнивать и выбирать информационный материал, переводить знания, умения и навыки, полученные при изучении информатики, на уровень межпредметных связей и надпредметных понятий.

На уроках информатики эффективна организация самостоятельного поиска информации, учащиеся знакомятся с новыми источниками информации, которые будут актуальными для изучения других дисциплин (электронные учебники, видеоуроки и т. д.). Но при такой работе учитель должен направлять учеников: проверенные сайты и адреса. Также поток информации большой и противоречивый, учеников нужно учить критически относится к любой информации. Важным является то, чтобы ученики могли анализировать сообщения одноклассников.

Организованная работа по развитию информационной культуры способствовала тому, что ученики стали осознаннее подходить к использованию и подбору информации. Это подтверждают и данные повторного опроса, и деятельность на уроках. Большее число учеников стали понимать, что такое информационная культура 63\% (20 учеников), увеличилось количество учеников, которые считают, что информация важна в жизни человека. Важным моментом является то, что ученики стали использовать компьютер для учебы.

Если у учащихся заложены основы осознания необходимости быть информационно культурным, грамотным человеком, информационная культура ученика будет развиваться и совершенствоваться от класса к классу.

Показателем результативности формирования информационной культуры являются и результаты успеваемости по предмету, положительная мотивация к обучению, активизация познавательной деятельности обучающихся, сформированные навыки исследовательской деятельности, обеспечивающие доступ к различным справочным системам, электронным библиотекам, другим информационным ресурсам.

\section{Список литературы}

1. Гендина Н.И. Дидактические основы формирования информационной культуры // Материалы областной научно-практической конференции, г. Кемерово, 26-28 ноября 2001 г. / под общ. ред. Н.И. Гендиной, Г.А. Стародубовой. - Кемерово, 2001.

2. Груздева Е.В. Профилактика интернет-зависимости подростков / Е.В. Груздева, И.П. Иванова // Психолого-педагогическое сопровождение детей группы риска: проблемы, опыт, перспективы. - 2016. - С. 28-32. 
3. Иванова И.П. Социально-педагогические условия социализации младших школьников в интернет-среде / И.П. Иванова // Современные проблемы науки и образования. 2020. - №3. - С. 28.

4. Каракозов С.Д. Информационная культура в контексте общей теории культуры личности // Педагогическая информатика. - 2000. - №2.

5. Коротеева О.С. Новые образовательные технологии в информационном пространстве / О.С. Коротеева, Л.В. Хорева // Образовательные технологии. - 2008. - №2. - С. 64-74.

Бахмисова Мария Алексеевна аспирант, ассистент

ФГБОУ ВО «Чувашский государственный университет им. И.Н. Ульянова» г. Чебоксары, Чувашская Республика

\section{ВНЕДРЕНИЕ 3D-ТЕХНОЛОГИЙ В ОБРАЗОВАТЕЛЬНУЮ ДЕЯТЕЛЬНОСТЬ: ВРЕМЯ ГОТОВИТЬ ИНЖЕНЕРОВ БУДУЩЕГО}

Аннотация: в статье приведены моменты из занятий, примеры работ по 3D-моделированию, 3D-печати и прототипированию для учащихся школь. Современным школьникам сейчас актуальна и очень интересна технология 3D-печати и объемное моделирование, поэтому они с удовольствием осваивают данные компетенции, умения, навыки в рамках дополнительных занятий по предметам «Технологии» в школах и дополнительных иентрах, таких как ДНК им. С.А. Абрукова г. Чебоксары.

Учащиеся быстро привыкают к традичионым методам обучения, $u$ даже проекты не всегда пробуждают их интерес, поэтому данный опыт занятий по 3D-моделированию, печати и 3D-прототипированию для учащихся школ будет актуален.

Ключевые слова: иифровая трансформачия, иифровое образование, 3D-графика, Autodesk 3Ds Max, 3D-моделирование, иифровые технологии.

Сегодня очень быстро внедряются инновации в рамках цифровизации образования, и в связи с этим изменяются и требования к техническим профессиям, связанным с промышленным производством, переосмысляются задачи специалистов, которым предстоит работать на «умных» заводах, оснащенными по передовым технологиям, или проводить научные исследования. Поэтому перед школой и вузами стоит ответственная задача - в рамках профориентации дать будущим инженерам, технологам, конструкторам, проектировщикам достаточные знания и практические навыки в области современных технологий, чтобы они были полностью готовы к цифровому миру.

Поддержка инженерного образования - одна из приоритетных стратегических задач развития России. К одному из данных приоритетных направлений относится 3D-моделирование, 3D-печать, прототипирование. Уже сегодня учащиеся школ осваивают навыки 3D-моделирования и печати. 3D-технологии активно применяется в самых различных областях: от промышленности и дизайна до медицины и искусства и развивается очень быстро. 
Цифровая трансформация в настоящее время касается любой сферы, так же происходит и в образовании. Сейчас почти в каждой современной школе, техникуме, университете висят интерактивные доски, у школьников есть электронные дневники, а преподаватели активно пользуются социальными сетями, чтобы оставаться с учащимися на связи и консультировать по возникающим вопросам домашней работы онлайн. И это практично. В основе лежит принцип смешанного обучения: современные технологии позволяют повысить эффективность преподавания за счет большей визуализации материала, помогают развить личностные качества учащихся - умение анализировать, планировать, самодисциплину, чувство ответственности.

Поддержка инженерного образования - одна из приоритетных стратегических задач развития России. К одному из данных приоритетных направлений относится 3D-моделирование, 3D-печать, прототипирование. Уже сегодня учащиеся школ осваивают навыки 3D-моделирования и печати. Сегодня 3D-технологии активно применяется в самых различных областях: от промышленности и дизайна до медицины и искусства.

Еще одним важным направлением цифровизации образования является воспитание у школьников и студентов стремления к саморазвитию. Как показывает практика, современные тенденции развития 3D-технологий диктуют новые правила в организации процессов обучения и подготовки. Знакомство детей с 3D-технологиями в школе и в дополнительных образовательных кружках технического и творческого направления очень влияет на реализацию творческого потенциала личности [1].

В качестве примера в статье приведены моменты из занятий по 3D-моделированию, 3D-печати и прототипированию для учащихся школ. Современным школьникам сейчас очень интересна технология 3D-печати и объемное моделирование, поэтому они с удовольствием осваивают данные компетенции, умения, навыки в рамках дополнительных занятий по предметам «Технологии» в школах и дополнительных центрах, таких как ДНК им. С.А. Абрукова г. Чебоксары. Данные занятия важны для учащихся, так как, во-первых, развиваются навыки пространственного и логического мышления, во-вторых, поможет школьнику найти актуальную интересную профессию в будущем и в-третьих, ребята активно вовлекаются в проектную деятельность, параллельно изучая введение в черчение, и др. науки. Учащиеся быстро привыкают к традиционным методам обучения, и даже проекты не всегда пробуждают их интерес, поэтому данный опыт занятий по 3D-моделированию, печати и 3D-прототипированию для учащихся школ будет актуален.

3D-моделирование - это проектирование трехмерной модели по разработанному чертежу или эскизу. Начинается объемное моделирование с построения простейших твердотельных объектов в программе Autodesk Tinkercad, Sketchup, 3ds-max, без привязки к размерам, постепенно идет усложнения задачи и уже на втором занятии ребята проектируют свой учебный кабинет по размерам, которые измерили самостоятельно при помощи рулетки, а уже на третьем и четвертом- без особой сложности чертят и моделируют объемную модель своей школы по заданным размерам. 


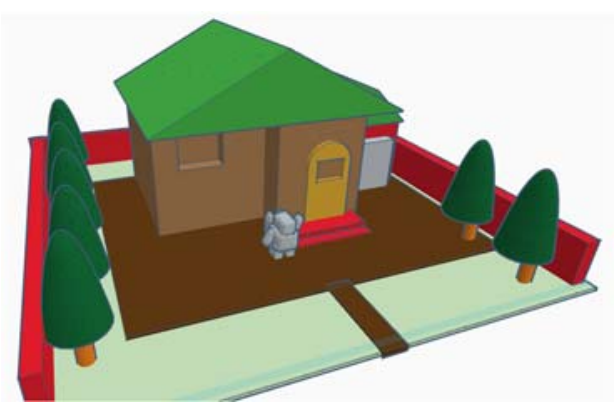

Рис. 1. Работа учащегося школы на первом занятии при знакомстве c Autodesk TinkerCad

3D-печать - это построение реального объекта по созданному на компьютере образцу 3D-модели. После построения модели, идет ее сохранения в формате STL-файла, после чего 3D-принтер, на который выводится файл для печати, формирует реальное изделие. Сам процесс печати - это ряд повторяюшихся циклов, связанных с созданием трёхмерных моделей. нанесением на рабочий стол (элеватор) принтера слоя расходных материалов, перемешением рабочего стола вниз на уровень готового слоя и удалением с поверхности стола отходов.

Циклы непрерывно следуют один за другим: на первый слой материала наносится следующий. элеватор снова опускается и так до тех пор. пока на рабочем столе не окажется готовое изделие. Применение 3D-печати - это серьезная альтернатива традиционным методам прототипирования. 3D-технологии позволяют полностью исключить ручной труд и необходимость делать чертежи и расчёты на бумаге, так как весь процесс построения модели идет в компьютерной программе. в которой есть возможность увидеть разработанную модель со всех ракурсов, и если необходимо, устранить недостатки.

Знакомство с 3D-принтером происходит разбора его основных элементов, применяемых материалов для печати, разновидностей и видов принтеров, а также метода его работы. Перед началом работы необходима обязательная настройка принтера. Для учеников школы 3D-печать уже изменила границы возможного. Радость творческого процесса вполне оправдывает подчас сложную работу. Ребята также уже задумываются над тем, где можно применить 3D моделирование и 3D-печать в будущей карьере.

Также в рамках занятий предусматривается проведение и участие во всероссийских конкурсах, олимпиадах и конференциях, где участникам предлагается создать различные модели, при создании которых нужны не только hard skills, но и soft skills. 


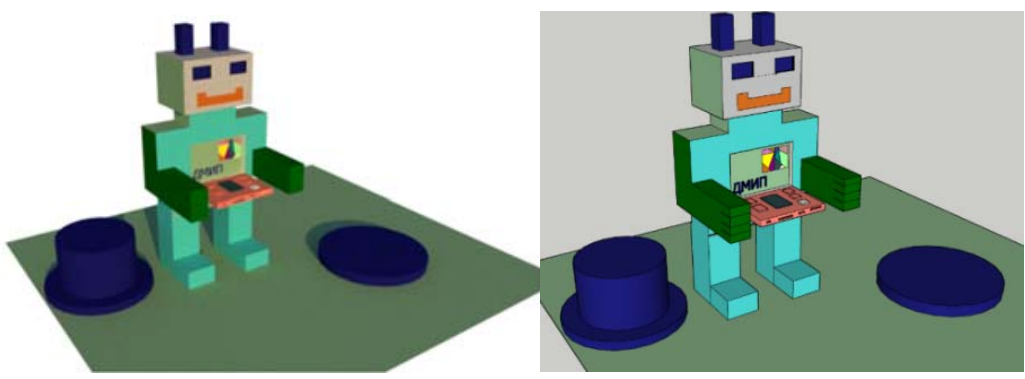

Рис. 2. Работа «Робот ДМИП» учащегося школы для участия во Всероссийской олимпиаде школьников, выполненная в программе Sketchup и V-ray рендер

C обучающимися в рамках занятий идет знакомство с 3D-принтером марки PICASO 3D. Для дальнейшей работы устанавливается специальная программа Polygon 2.0 и в ней выводятся настройки печати, также, есть программа Cura, которая сложнее, но также отлично справится с настройкой печати моделей.

Существуют различные технологии трёхмерной печати. Разница между ними заключается в способе наложения слоёв изделия. Чтобы разбираться с настройками и работой $3 \mathrm{D}$-принтера с учащимися сначала проводится пробная печать куба, и др. простых объемных тел, а затем уже разработанной по размерам головоломки, которую они после печати также должны собрать.

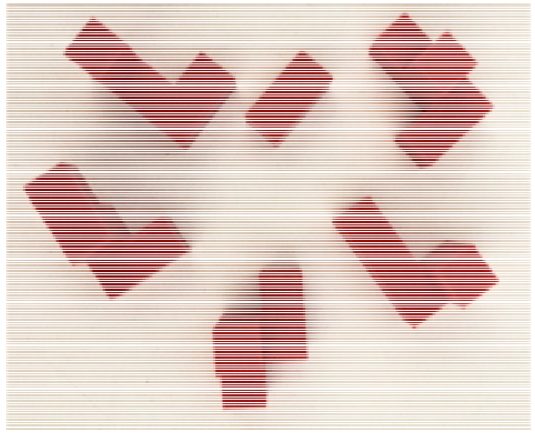

Рис. 3. Головоломка, напечатанная на 3D-принтере

После того, как учащиеся начинают чуть свободнее владеть компьютерными программами для 3D-моделированию, перед ними ставится задача разработки своего проекта и его дальнейшая защита.

Изучение 3D-технологий обусловлено практически повсеместным использованием трехмерной графики в различных сферах деятельности, знание которой становится все более значимым для полноценного развития личности. На сегодняшний день уже во многих учебных заведениях активно вводят дополнительные занятия по моделированию, и это правильно. Ведь 3D - это не только моделирование, визуализация, анимация 
и трехмерная печать. Но и технологии дополненной реальности, есть трехмерные тренажеры, симуляторы, трехмерное видео. Все это можно изучать, а еще лучше создавать в школьном возрасте, т.к. изучение программных продуктов формирует профессиональные компетенции, происходит вовлечение учащегося в научно-техническое творчество и способствует самоопределению в выборе профиля обучения.

\title{
Список литературы
}

1. Бахмисова M.A. Трехмерное моделирование в 3Ds-Max для учащихся в условиях развития цифрового образования // Педагогические и социальные вопросы образования: материалы Междунар. науч.-практ. конф. (Чебоксары, 30 март 2020 г.) / редкол.: Ж.В. Мурзина [и др.] - Чебоксары: ИД «Среда», 2020. - С. 74-77.

2. Бахмисова М.А. ВІМ-технологии и анализ междисциплинарных связей по дисциплинам в образовательной среде строительного факультета / М.А. Бахмисова, Л.А. Сакмарова // Социологические и педагогические аспекты образования: материалы Междунар. науч.практ. конф. - Чебоксары: ИД «Среда», 2019. - С. 88-93.

\author{
Дорофеев Андрей Сергеевич \\ канд. техн. наук, доцент \\ Научный руководитель \\ Сосинская Софья Соломоновна \\ канд. техн. наук, доцент \\ ФГБОУ ВО «Иркутский национальный \\ г. Иркутск, Иркутская область
} исследовательский технический университет»

\section{РАЗРАБОТКА МОДУЛЯ ДЛЯ ИНДИВИДУАЛИЗАЦИИ ПРОЦЕССА ОБУЧЕНИЯ В МОODLЕ}

Аннотация: в связи с мировой пандемией, связанной с распространением COVID-19, значительно возросла роль систем дистанционного обучения в современном образовании. В статье предлагается создать плагин для СДО Moоdle для сбора в прочессе обучения статистических данных, которые позволят получить информацию о прочессе обучения, сложности и эффективности разработанного курса для возможной модификации его структуры и настройки под обучающегося.

Ключевые слова: СДО, система дистанџионного обучения, Moоdle, моделирование процесса обучения, цепи Маркова.

Современное образование - это не только результат обучения, воспитания и развития личности, но и результат самообучения и саморазвития личности [1].

Применение в учебном процессе системы обучения позволяет систематически и оперативно оказывать обучаемому необходимую дидактическую помощь, выполнять непрерывный контроль за действиями обучаемого в процессе обучения, развивать познавательную активность и инициативу обучаемого, снизить долю непроизводительного труда преподавателя [2]. 
Ситуация с распространением коронавирусной инфекции в 2020 г. дала новый импульс системам дистанционного обучения (СДО). В настоящее время в Иркутском политехе широко применяется СДО «MOODLE» (Modular Object-Oriented Dynamic Learning Environment) бесплатная система электронного обучения, представляющая собой открытоe web-приложение, на базе которого можно создать специализированную платформу для создания электронных курсов, проведения обучения и тестирования. Открытость данной СДО позволяет создавать участникам сообщества MOODLE плагины - модули, с помощью которых можно изменить дизайн системы и расширить ее функциональные возможности системы [3].

В работе предлагается создание модуля, позволяющего на основе моделирования процесса обучения и использовании аппарата однородных цепей Маркова получить вероятностные оценки характеристик процесса обучения.

Матрица переходных вероятностей для однородной цепи Маркова имеет вид:

$$
\begin{aligned}
& \mathrm{p}_{11} \mathrm{p}_{12} \ldots \mathrm{p}_{1 \mathrm{j}} \ldots \mathrm{p}_{1 \mathrm{n}} \\
& \mathrm{p}_{21} \mathrm{p}_{22} \ldots \mathrm{p}_{2 \mathrm{j}} \ldots \mathrm{p}_{2 \mathrm{n}} \\
& \left\|p_{\mathrm{ij}}\right\|=\quad \quad \mathrm{p}_{\mathrm{il}} \mathrm{p}_{\mathrm{i} 2} \ldots \mathrm{p}_{\mathrm{ij}} \ldots \mathrm{p}_{\mathrm{in}} \\
& p_{n 1} p_{n 2} \ldots p_{n j} \ldots p_{n n}
\end{aligned}
$$

Распределение вероятностей на k-м шаге вычисляется по следующей рекуррентной формуле:

$$
p_{j}(k)=\sum_{i=1}^{n} p_{i}(k-1) p_{i j}(\mathrm{k}=1,2, \ldots ; \mathrm{j}=1,2, \ldots, \mathrm{n})
$$

Для сравнения рекуррентное соотношение, определяющее распределение вероятностей на k-м шаге для неоднородной цепи, принимает вид [4]:

$$
p_{j}(k)=\sum_{i=1}^{n} p_{i}(k-1) p_{i j}(k)(\mathrm{k}=1,2, \ldots, \mathrm{n} ; \mathrm{j}=1,2, \ldots, \mathrm{n})
$$

Процесс обучения можно рассматривать как динамическую систему, находящуюся в каждый из моментов времени $\mathrm{t}_{\mathrm{k}}$ в одном из $\mathrm{n}$ состояний [6]. Это изменение определяется матрицей переходных вероятностей Р (1). Если исключить из матрицы Р строки и столбцы, которые соответствуют поглощающим состояниям, и обозначить полученную матрицу через Q, можно вычислить фундаментальную матрицу цепи Маркова:

$$
N=(I-Q)^{-1},
$$

где I - единичная матрица.

Каждый элемент матрицы $\mathrm{N}$ есть среднее число пребываний процесса в состоянии $\mathrm{s}_{\mathrm{j}}$. В данной модели достаточно рассматривать только первую строку матрицы $\mathrm{N}$ (так как изучение определенного курса (раздела) начинается из состояния $\mathrm{s}_{1}$ ). При известных среднем времени, необходимом для прохождения ј-го шага процесса обучения - трудоемкости $\Theta_{j}$, и 
первой строке матрицы $\mathrm{N}$ можно вычислить среднюю трудоемкость прохождения всего курса (раздела) $\Theta_{\Sigma}$ :

где $l$ - размерность матрицы Q.

$$
\Theta_{\Sigma}=\sum_{j=1}^{l} n_{1 j} \cdot \Theta_{j},
$$

Для оценки дисперсии трудоемкости курса вычисляется матрица дисперсий числа пребываний процесса во множестве невозвратных состояний:

$$
D=N\left(2 N_{d g}-I\right)-N_{s q}
$$

где $\mathrm{N}_{\mathrm{dg}}-$ матрица, полученная выделением из матрицы $\mathrm{N}$ диагональных элементов, $\mathrm{N}_{\mathrm{sq}}$ - матрица, в которой каждый элемент матрицы $\mathrm{N}$ возведен в квадрат [5].

Для вычисления среднеквадратичного отклонения (СКО) числа пребываний процесса во множестве невозвратных состояний от среднего применяется известная формула:

$$
\sigma_{i j}=\sqrt{d_{i j}}
$$

Для нахождения средней трудоемкости процесса зададим оценки трудоемкости, которые первоначально оцениваются экспертно, а затем уточняются на основе накопленных экспериментальных данных прохождения каждого узла изучаемого курса.

Используя аппарат теории конечных цепей Маркова, можно найти основные характеристики процесса изучения курса (распределение вероятностей, математическое ожидание, дисперсию, СКО). Зная трудоемкости изучения каждого из разделов, на которые разбит курс, можно подсчитать априорную трудоемкость завершения процесса изучения курса, в соответствии с которой и можно разбивать курс на разделы.

Входной информацией для расчетов являются состояния, трудоемкости и таблица вероятностей переходов. Первоначальная трудоемкость и вероятности переходов оцениваются экспертно преподавателем-разработчиком курса. По мере накопления данных вероятности переходов рассчитываются в соответствии со статистикой прохождения обучения. На каждом шаге (занятие, час и т. д.) для каждого обучаемого накапливается число переходов из одного состояния в другое и количество нахождений системы в каждом из состояний. Условная вероятность перехода из одного состояния в другое равна отношению:

$$
P_{i j(t)}=P\left(S_{j(t)} / S_{i(t-1)}\right)=\frac{m_{i j}}{a_{i}},
$$

где $\mathrm{m}_{\mathrm{ij}}$ - количество нахождений обучаемого в состоянии $\mathrm{S}_{\mathrm{j}}$ при условии его нахождения в состоянии $\mathrm{S}_{\mathrm{i}}$ на предыдущем шаге; $\mathrm{a}_{\mathrm{i}}$ - общее число нахождений обучаемого в состоянии $\mathrm{S}_{\mathrm{i}}$.

Переходы нескольких обучаемых в определенные состояния являются независимыми. Зная вероятности переходов каждого k-го обучаемого, можно найти средние статистические значения вероятностей переходов, которые в дальнейшем сохраняются в профиле курса: 


$$
\overline{P_{i j}}=\frac{\sum_{k=1}^{K O L} P_{i j}^{k}}{\sum_{j=1}^{n} \sum_{k=1}^{K O L} P_{i j}^{k}},
$$

где $\mathrm{n}$ - размерность матрицы переходов; KOL - общее количество обучаемых.

Формула (9) включает нормирование элементов вычисленной матрицы.

Методика использования системы включает в себя несколько этапов (рассматриваются создание курса и обучение):

I. Подготовительный этап

1) вход преподавателя-дизайнера курса в систему (администратор предварительно регистрирует всех пользователей системы);

2) формирование разделов курса, их взаимосвязь;

3 ) формирование заданий на лабораторные и контрольные работы, занесение контролирующих вопросов, тестов;

4) тестирование студента для выяснения первоначального уровня знаний.

II. Обучение.

1) вход студента в систему (ввод имени пользователя и пароля);

2) чтение и изучение теоретического материала студентом;

3) тестирование по различным разделам дисциплины с выдачей результата и возможным откатом к началу курса, темы, параграфа и т. д.;

4) тестирование по всему курсу.

III. Получение результатов обучения.

1) вывод результатов по темам, по курсу; также возможен вывод модели текущих знаний конкретного студента, из которой легко видеть, что изучено и что предстоит еще изучить;

2) выдача набранного балла и рекомендаций (изучение основ дисциплины, каких-то отдельных тем, повторное изучение дисциплины, более углубленное изучение и т. д.).

Накопленные в процессе обучения статистические данные для конкретного курса позволяют получить информацию о процессе обучения, сложности и эффективности разработанного курса для возможной модификации его структуры с целью настройки на конкретный уровень знаний обучающихся.

\section{Список литературы}

1. Попов В.В. Дистанционное образование в свете креативной педагогики / В.В. Попов // Дистанционное образование. - 1997. - №2 - С. 13-18.

2. Пасхин Е.Н. Автоматизированная система обучения Экстерн / Е.Н. Пасхин, А.И. Митин. - М.: Изд-во Моск. ун-та, 1985. - 144 с.

3. Система электронного обучения и тестирования Moodle: обзор возможностей [Электронный ресурс]. - Режим доступа: https://www.ispring.ru/elearning-insights/moodle

4. Вентцель Е.С. Теория случайных процессов и ее инженерные приложения: учеб. пособ. для втузов / Е.С. Вентцель, Л.А. Овчаров. - 2-е изд., стер. - М.: Высш. шк., 2000. - 383 с. $272 \mathrm{c}$.

5. Кемени Дж. Конечные цепи Маркова / Дж. Кемени, Дж. Снелл. - М.: Наука, 1970. -

6. Дорофеев А.С. Модель обучающего курса и реализация программной оболочки дистанционного обучения: системный и объектный подходы / А.С. Дорофеев: дис. ... канд. техн. наук: 05.13.01. - Иркутск, 2006. - 160 с. 


\section{Дудковская Ирина Алексеевна канд. пед. наук, доцент, заведующая кафедрой Куйбышевский филиал ФГБОУ ВО «Новосибирский государственный педагогический университет» г. Куйбышев, Новосибирская область \\ ЭЛЕКТРОННОЕ УЧЕБНОЕ ПОСОБИЕ КАК СПОСОБ РАЗВИТИЯ ПОЗНАВАТЕЛЬНЫХ УНИВЕРСАЛЬНЫХ УЧЕБНЫХ ДЕЙСТВИЙ ОБУЧАЮЩИХСЯ НА УРОКАХ ИНФОРМАТИКИ}

Аннотация: в статье рассматривается электронное учебное пособие как способ развития познавательных универсальных учебных действий обучающихся на уроках информатики. Представлень различные подходы к определению понятия «электронное учебное пособие» 8 научно-методической литературе. Перечислень достоинства и недостатки электронной формы учебников и учебных пособий.

Ключевые слова: электронное учебное пособие, электронная форма учебников, обучение, познавательные универсальные учебные действия.

С приходом технического прогресса, а затем и полной цифровизацией всех сфер жизнедеятельности человека, привычные печатные книги и журналы теряют свою значимость и меркнут на фоне предлагаемых усовершенствованных электронных книг, журналов, пособий. Конечно, система российского образования не осталась в стороне, все большее количество педагогов и руководителей постоянно повышают свои навыки в области ИКТ-технологий и компетенций. На сегодняшний день, очень сложно встретить педагога, который не был бы знаком с такими понятиями, как интерактивный урок, интегрированное учебное занятие, урок с применением дистанционных технологий и уроки с применением ИКТ. Наряду с традиционными формами и методами проведения уроков, обязательным становится применение различных интернет-ресурсов, для повышения мотивации к предмету, а также к образованию у школьников в целом. Особенно актуальным эти методы и формы стаи в условиях самоизоляции и пандемии, ведь все российские школьники и педагоги были вынуждены работать в онлайн-режиме. По мнению многих специалистов в области педагогики, именно применение различных дистанционных технологий и методов ИКТ положительно влияют на динамику развития познавательных универсальных учебных действий (в том числе и электронных учебных пособий) $[1 ; 2]$. Разберем более подробно понятие и виды электронных учебных пособий, а также их основные преимущества и недостатки.

Для того чтобы понять является ли «электронное учебное пособие» эффективным средством развития познавательных универсальных учебных действий школьников при обучении информатике, необходимо ознакомимся с рабочими определениями понятия «электронное учебное пособие» и выявить положительные и отрицательные стороны его применения в учебном процессе. 
Анализируя различные научные информационные источники, было замечено, что нет единого определения понятия «электронное учебное пособие». Результаты анализа рабочих определений этого понятия представлены в таблице 1.

Таблица 1

Различные подходы к определению понятия «Электронное учебное пособие» в научно-методической литературе

\begin{tabular}{|c|c|c|}
\hline № & Автор & Рабочие определение понятия \\
\hline 1 & $\begin{array}{l}\text { О.Н. Маслени- } \\
\text { кова (2016 г.) }\end{array}$ & $\begin{array}{l}\text { Электронное учебное пособие (по определению спе- } \\
\text { циалистов ЮНЕСКО, е-learning - обучение с помо- } \\
\text { щью Интернета и мультимедиа) - это информацион- } \\
\text { ное средство, благодаря которому возможно приме- } \\
\text { нение электронных технологий в обучении }\end{array}$ \\
\hline 2 & $\begin{array}{l}\text { Я.А. Ваграменко } \\
(2000 \text { г.) }\end{array}$ & $\begin{array}{l}\text { Электронное учебное пособие - это «помощник», } \\
\text { разработанный в общедоступном формате, имею- } \\
\text { щий лицензионные ограничения для участников об- } \\
\text { разовательной деятельности }\end{array}$ \\
\hline 3 & $\begin{array}{l}\text { М.И. Семенов } \\
(2005 \text { г.) }\end{array}$ & $\begin{array}{l}\text { Электронная форма учебников и учебных пособий - } \\
\text { это аудиовизуальное средство, необходимое для } \\
\text { адаптации школьника в информационном мире }\end{array}$ \\
\hline 4 & $\begin{array}{l}\text { И.Г. Судак } \\
(2011 \text { г.) }\end{array}$ & $\begin{array}{l}\text { Электронная форма учебников и учебных пособий - } \\
\text { это стимулятор разнообразной творческой, самосто- } \\
\text { ятельной и исследовательской деятельности }\end{array}$ \\
\hline 5 & $\begin{array}{l}\text { Е.С. Полат } \\
(2015 \text { г.) }\end{array}$ & $\begin{array}{l}\text { Электронная форма учебников и учебных пособий- } \\
\text { это учебник (учебное пособие), разработанной в со- } \\
\text { ответствии с требованиями Приказа Минобрнауки } \\
\text { Российской Федерации и реализованный в формате } \\
\text { ЕРUВ, как специальная программа, содержащая } \\
\text { электронные образовательные ресурсы и расмирен- } \\
\text { ный набор инструментов навигации }\end{array}$ \\
\hline
\end{tabular}

Исходя из всего описанного выше, следует, что определение «Электронная форма учебника и учебного пособия», предложенное Е.С. Полат является наиболее полным и развернутым.

Несмотря на то, что каждый автор рассматривает рабочее определение понятия «Электронное учебное пособие» в разных аспектах, каждое из них определяет преимущество его применения на уроках информатики в отличие от печатных пособий.

Перечислим достоинства и недостатки электронной формы учебников и учебных пособий. К достоинствам можно отнести следующие нижеперечисленные возможности.

1. Адаптация и оптимизация пользовательского интерфейса, настроенного под индивидуальные запросы обучающегося. Возможность использования гипертекста и всплывающих окон с различным содержимым.

2. Использование различных средств воздействия на обучающихся, например, звуковые и анимационные модели сопровождающие теоретический материал.

3. Удобный механизм навигации в пределах электронной формы учебника или учебного пособия. Это значительно облегчает поиск необходимой информации (не нужно листать и запоминать номер страницы, для этого используются гиперссылки).

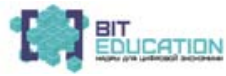


4. При использовании сетевых обучающих структур возможно обсудить положения учебника с другими школьниками (в электронном читальном зале), оставаясь на своем рабочем месте.

5. Возможность встроенного автоматизированного контроля уровня знаний обучающегося, и на этой основе автоматический выбор соответствующего уровню знаний слоя учебника.

6. Адаптация изучаемого материала к уровню знаний школьников, и как следствие, улучшенное восприятие и усвоение информации.

7. Интерактивное взаимодействие между обучающимися и элементами электронной формы учебника и электронного учебного пособия. Это главное преимущество перед печатными изданиями.

Перейдем к основным недостаткам электронных форм учебников и электронных пособий.

1. Отсутствие определенной концепции, лежащей в основе печатных изданий.

2. Большинство электронных учебных материалов несут поверхностные знания, не углубляясь в материал по теме.

3. Текст на экране хорошо воспринимается не всеми категориями обучающихся.

4. Методически непродуманное построение электронной формы учебника или учебного пособия грозит сковыванием самостоятельной деятельности школьников.

5. Избыточность мультимедийных средств может отвлекать обучающихся от конкретного задания и даже раздражать, не давать сосредоточиться.

Таким образом, благодаря использованию этих электронных средств обучения, школьники, развивая свои способности самостоятельного контроля при получении заряда положительных эмоций, учатся самостоятельно получать новые знания и новые навыки саморегуляции.

Использование такого средства обучения как электронная форма учебного пособия требует от учителя умений проводить сопоставительный анализ содержания школьного курса информатики, умений отбирать важную информацию и средства наглядности. В ходе анализа результатов исследований практикующих учителей информатики относительно использования электронных образовательных ресурсов, в том числе и электронной формы учебного пособия (далее ЭУП), выяснилось, что целесообразнее их применять не только на каждом уроке информатики, но и на каждом его этапе. Использование ЭУП на уроках информатики открывает принципиально новые возможности для развития познавательных универсальных учебных действий, обучающихся в процессе организации обучения и повышает уровень усвоения содержания предмета. С помощью применения ЭУП как средства обучения и развития познавательных универсальных учебных действий возможно обогащение содержания предмета, так как развитие информационных технологий происходит постоянно, то ЭУП кардинально отличается от традиционных, «застывших» и ежегодно не обновляемых учебниках.

\section{Сиисок литературы}

1. Дудковская И.А. Владение инновационными технологиями в образовании как одно из необходимых профессиональных качеств современного педагога // Психолого-педагогическое образование в современных условиях: материалы Всерос. науч.-практ. конф. - 2019. C. $104-108$.

2. Ижденева И.В. Особенности когнитивного обучения информатике, стимулирующие развитие познавательного интереса // Конструктивные педагогические заметки. - 2020. №8.2 (14). - C. 223-235. 


\title{
ЛУЧШИЕ ПРАКТИКИ «ВЫЗОВ ЦИФРОЙ» ПО ПРЕДМЕТНОЙ ОБЛАСТИ «ТЕХНОЛОГИЯ»
}

\author{
Никифорова Ольга Власовна \\ учитель \\ МБОУ «СОШ №9» \\ г. Чебоксары, Чувашская Республика
}

\section{ЭФФЕКТИВНОЕ ИСПОЛЬЗОВАНИЕ ИКТ НА УРОКАХ ТЕХНОЛОГИИ В СОВРЕМЕННЫХ УСЛОВИЯХ}

Аннотация: статья посвящена актуальной проблеме современного образования - электронному обучению. Основная задача статьи - обосновать использование информационных технологий как современную форму обучения. Выделены проблемы, решаемые обучаюшимися и учителем с использованием интернет-ресурсов. Показано, что эффективность информационного обучения определяется использованием педагогических технологий, которые лежат в основе проектирования и даёт реальную возможность улучшить свои знания по технологии.

Ключевые слова: информационная технология, средство, форма, тренинг кабинет.

Часто мы, учителя, задаемся вопросом: так ли уж нам необходимо владеть компьютерной технологией в своей педагогической деятельности? И как мы можем использовать свои навыки владения информационной технологией на уроке технологии? Чтобы ответить на поставленные вопросы, мы должны уточнить с какой целью будем использовать компьютерную технологию. Как известно цели использования информационных технологий в современной школе разнообразны, но самым главным из них является облегчение учителю работы, а также повысить уровень мотивации школьников, пробудить в них интерес к познавательной деятельности. При этом сохраняется индивидуальный подход в обучении ученика. Кроме того, важно помнить, что сегодня одна из актуальных задач перед учителем стоит развитие у учеников информационной грамотности, научить их владению информационными технологиями, помочь обрести стиль мышления, актуальный для информационного общества.

Постараемся разобраться, на каких этапах школьного урока лучше использовать информационные технологии, и в какой форме?

Сегодня школьники стараются идти в ногу с современной технологией. И мы учителя, сталкиваемся с такой проблемой на уроке, что обучающиеся на уроке больше интересуются с возможностями новоприобретенной техникой в виде телефона с различными возможностями, чем объяснением новой темы. Попросту говоря, они «зависают» в своих телефонах на уроке, и чтобы мы не предпринимали, вывести их из этого состояния достаточно сложно, и причем на уроке затрачиваются такое драгоценное для нас время. Вспомните себя: когда мы увлечены чем-то новым вызывающим большой интерес для нас процессом, то достаточно трудно нас оторвать от этого занятия. Вот тогда я подумала, как перевести этот порог 
во благо. И нашла решение в следующем: сегодня в интернете достаточно разной информации по одной и той же тематике. И вот мы ищем на уроке технологии на страничках различных сайтов интернета информацию по теме урока и сравниваем ее с тем, что сказано в учебнике. При этом мы одновременно решаем проблему нехватки учебников, а также развиваем у учеников информационную грамотность, учим их владению информационными технологиями, помогаем обрести стиль мышления, актуальный для информационного общества.

Решение другой проблемы - как катастрофической нехватки времени на уроке и одновременное учитывание различных психологических темпераментов обучающихся на уроке, осуществляю через использование на уроке видеоматериалов, которые сами снимаем, монтируем и озвучиваем. Хотя сегодня в сети интернет можно найти достаточное количество видеоматериалов на различные темы, но согласитесь, созданием видео занимаются различные дилетанты, чаще не умеющие общаться на профессиональном языке, или плохо владеющие профессиональными знаниями, умениями и навыками. Преимущество использования видеоматериала заключается еще и в том, что обучающийся не освоивший материал или какой-либо вопрос данного материала, может заново просматривать его несколько раз, пока не освоит.

Немаловажный вопрос занимает для учителя закрепление полученных знаний учеником. Как же успеть проверить, все ли ученики поняли тему сегодня на уроке. Здесь меня выручает различные методы обучения, и одним из таких методов является тренинг кабинет. На просторах современного интернета существуют достаточно большое количество подобных peсурсов. Мой интерес привлек сервис Online Test Pad. Чем он так интересен? Его платформа представляет собой многофункциональный конструктор для создания разнообразных учебных материалов и состоит из нескольких сервисов.

Конструктор тестов. Который поддерживает 14 типов вопросов: единственный выбор, множественный выбор, ввод числа, ввод текста, ответ в свободной форме, установление последовательности, установление соответствий, заполнение пропусков - числа / текст, интерактивный диктант, последовательное исключение, слайдер (ползунок), загрузка файла, служебный текст. При создании тестов есть возможность использовать различные картинки по теме урока. Тест всегда доступен для onlineиспользования и его смогут пройти только те, кому отправляется ссылка.

Конструктор комплексных заданий. Комплексное задание может быть использовано для различных целей. Например, для проведения викторин, контрольных, самостоятельных и домашних работ. В одно комплексное задание одновременно можно включить неограниченное количество тестов. Таким образом, в конце изучения раздела можно провести урок повторения.

Создание учебного материала имеет различные формы в виде текста, загрузки файла, видео и др. материалов. При этом отпадает необходимость иметь учебники по технологии дома каждому ученику. Перед тем как выполнить задание, сначала есть возможность повторить, причем необязательно читать, а можно посмотреть видеоролик.

Инструмент статистики. Необходим ученику для просмотра своего результата, статистики ответов и набранных баллов по каждому вопросу теста. В табличном виде представлены все результаты, регистрационные параметры тестов, результаты каждого элемента и итоговый результат, которые так же можно сохранить в Excel. 
В разделе под названием Офис учитель создает группы учеников, с которыми он будет работать. Офис имеет удобный интерфейс для организации и ведения списка всех своих учеников. Позволяет создавать отдельный тренинг-кабинет для каждого ученика, которые смогут войти в свой тренинг-кабинет под своим логином и паролем. В нем он настраивает свой профиль, выполняет поставленные задания, просматривает свои результаты, видит журнал успеваемости.

Для быстрого оценивания учителю доступен журнал успеваемости группы (с возможностью выгрузки в Excel), просмотр каждого результата, подробная статистика по всем элементам задания и результатам, графики потраченного времени. Вот такой уникальный ресурс, который помогает мне оставаться на связи со своими учениками в любое время. Но больше всего меня поразило на Online Test Pad, так это то, что на платформе с такими большими возможностями все сервисы предоставляются абсолютно бесплатно и становятся доступными сразу после регистрации. Сегодня в условиях распространения пандемии он как никогда помогает мне решать проблему обучения.

Как уже отмечалось, Основная профессиональная образовательная программа, согласно ФГОС, включает внеаудиторную самостоятельную работу как одну из форм организации учебного процесса.

Главной проблемой при организации самостоятельной работы является то, что у школьников не выработана психологическая установка на самостоятельное систематическое пополнение знаний и не развито умение ориентироваться в потоке научной и общественной информации при решении познавательных задач. В связи с этим, прежде всего, необходимо развивать способности и потребности обучающегося в самообразовании.

Моя роль как преподавателя состоит в том, чтобы для каждого определить оптимальный объем и сложность работы и реализовать план самообразования с соблюдением принципа доступности обучения. Тогда результатом выполнения внеаудиторной самостоятельной работы для каждого обучающегося станет осознание собственной успешности и компетентности, появится потребность в самообразовании.

Для руководства самим процессом самостоятельной работы обучающимися необходима регулярная консультационная помощь в преодолении затруднений. Ее осуществляю через компьютерную сеть, а именно через персональный сайт преподавателя, где для осуществления доступности источников информации сайт построен в виде электронного учебника, обучающиеся познакомившись с теоретическим материалом тут же могут проверить себя выполнив тестовое задание, для закрепления предлагается письменно ответит на вопросы и подготовить по данной теме более сложные работы.

Информационно-коммуникационные технологии создают широкие возможности для развития современного образования, прежде всего в направлении индивидуализации, создают условия для реализации творческого потенциала учителя и ученика.

\section{Список литературы}

1. Гафурова Н.В. Педагогическое применение мультимедиа средств: учеб. пособ. / Н.В. Гафурова, Е.Ю. Чурилова. - 2-е изд. перераб. и доп. - Красноярск: Сиб. федер. ун-т, 2018. - 204 c.

2. Камушкова Н.B. Online Test Pad - сервис конструкторов заданий [Электронный ресурс]. Режим доступа: https://blog.natalyakamushkova.ru/online-test-pad-servis-konstruktorov-zadanij/

3. Роготнева А.В. Организация проектной деятельности в школе в свете требований ФГОС: метод. пособ. /А.В. Роготнева, Л.Н. Тарасова. - М.: ВЛАДОС, 2018. - 120 с. 
Сергеева Алена Александровна канд. пед. наук, доцент

ФГБОУ ВО «Тульский государственный педагогический университет им. Л.Н. Толстого» г. Тула, Тульская область

\section{РЕАЛИЗАЦИЯ МЕЖПРЕДМЕТНЫХ СВЯЗЕЙ В РАМКАХ ПРЕДМЕТНОЙ ОБЛАСТИ «ТЕХНОЛОГИЯ» В УСЛОВИЯХ ЦИФРОВИЗАЦИИ ОБРАЗОВАТЕЛЬНОГО ПРОЦЕССА}

Аннотация: в статье рассмотрены основные способы реализации межпредметных связей в рамках предметной области «Технология» $в$ условиях цчифровизации образовательного прочесса. Автором раскрыт потенцииал социальных сетей «ВКонтакте», Instagram и ресурса YouTube для организации обучения в дистанционном формате.

Ключевые слова: циифровизация образовательного процесса, межпредметные связи, дистанциионное обучение, социиальнле сети, технология.

В условиях модернизации российского образования, предполагающей введение Федеральных государственных стандартов среднего (полного) общего образования нового поколения, акцентируется внимание на результаты образовательного процесса, выраженные в реализации основной образовательной программы среднего (полного) общего образования образовательными учреждениями [1].

Особое место в предметной области «Технология» занимают те проблемы, рассмотрение которых требует использования межпредметных связей в образовательном процессе. Они позволяют обеспечить единство знания, облегчить процесс понимания сути явления или процесса. Межпредметные связи способствуют лучшему формированию отдельных понятий внутри отдельных предметов, групп и систем, так называемых межпредметных понятий, то есть таких, полное представление о которых невозможно дать учащимся на уроках какой-либо одной дисциплины. Подобные связи в рамках различных предметных областей несут важную миссию в повышении практической и научно-теоретической подготовки учащихся, существенной особенностью которой является овладение школьниками обобщенным характером познавательной деятельности.

Изучение отдельных тем в рамках предметной области «Технология» тесно связано с основами различных естественнонаучных и гуманитарных наук, знания, приобретаемые обучающимися на уроках технологии, позволяют осмыслить им значимость применения на практике знаний по математике, физике, химии, биологии, изобразительному искусству и пр.

Достаточно весомую роль на уроках технологии отводится межпредметным связям при рассмотрении вопросов в разделе «Кулинария». Обучающимся на занятиях необходимо раскрывать значение их знаний по биологии, физике, химии для усвоения определенных понятий и терминов в рамках данного раздела.

Уроки в рамках материаловедения одежды связаны со знаниями учащихся по биологии, химии, физике. Биология помогает лучше

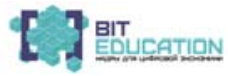


познакомиться со свойствами натуральных волокон и нитей, способами их получения и использования. Такие понятия, как прочность, упругая деформация, невозможно отделить от знаний по физике, эти свойства так и называются физико-механические. При изучении темы: химические волокна необходимы знания по химии, свойства целлюлозы, свойства различных веществ. При определении волокнистого состава тканей часто проводятся химические анализы.

Изучая раздел, связанный с моделированием и конструированием одежды, обучающиеся знакомятся с работой художника-модельера, учатся подбирать ткань к разработанным моделям, определять наиболее целесообразные средства художественного оформления швейных изделий, решать задачи сопоставления различных частей одежды. Учащиеся получают знания о том, как свойства, цвет, рисунок ткани влияют на выбор модели, зрительное ощущение пропорций в одежде. При построении чертежей выкроек швейных изделий необходимо производить расчеты по формулам, используя свои знания по математике.

Кроме того, многие разделы предметной области «Технология» связаны с изучением экономики: экономия материалов, электроэнергии, бережное отношение к оборудованию, инструментам и приспособлениями, знакомство с производительностью труда и себестоимостью продукции как экономическими категориями.

В рамках данного материала рассмотрим межпредметные связи в рамках предметной области «Технология», которые реализуются на базе МБОУ ЦО №4 г. Тулы. В условиях пандемии коронавирусной инфекции особое значение приобретает использование цифровых ресурсов для организации образовательного процесса.

В условиях дистанционного обучении педагогами МБОУ ЦО №4 г. Тулы было принято решение реализовать межпредметные связи на уроках технологии с использованием потенциала социальных сетей и YouTube.

Данный формат был выбран неслучайно: большинство обучающихсяподростков активно пользуются данным цифровым контентом, легко ориентируются в социальных сетях, владеют навыками представления там информации.

В качестве цифровых «платформ» были выбраны две социальные сети (ВКонтакте и Instagram) и ролики на различных YouTube-каналах.

«Вконтакте»- российская социальная сеть, популярная среди молодежи, позволяющая организовать безграничное общение по любым интересующим проблемам. Достоинством данной социальной сети является возможность создавать беседы с включением неограниченного количества участников [2].

На платформе Вконтакте были созданы специализированные беседы, посвященные обсуждению отдельных тем в рамках предметной области «Технология». Так при изучении элементов машиноведения, используя потенциал социальных сетей и разнообразные гиперссылки в них, мы обращаемся ко многих физическим вопросам (например, устройство, назначение, принцип действия механизмов машин), а также к черчению (составление кинематических схем), что крайне удобно сделать с использованием потенциала интернет-ресурсов.

Эта социальная сеть зарекомендовала себя как достаточно удобный мессенджер в формате дистанционного обучения: и педагог, и

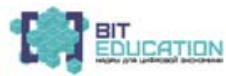


обучающиеся оперативно видят сообщения, могут отвечать на них с любых цифровых устройств. Подобный формат общения близок и понятен детям, они легко идут на контакт с педагогом, мотивированы на общение с одноклассниками и учителем.

Инстаграм - это международная социальная сеть для публикации фото, видео и текстового контента. Владельцы аккаунтов подписываются друг на друга и делятся разной информацией. Приложение Instagram бесплатно, легко скачивается на смартфон и используется без специальных навыков [3].

Достоинством данной социальной сети в рамках организации дистанционного обучения является возможность проводить оперативные прямые эфиры для освещения интересующих вопросов, выкладывать посты-фотогалереи, где пошагово можно пояснить то или иное явление, раскрыть межпредметный потенциал изучаемой темы. Особое место занимает в данной социальной сети система оценивания публикаций обучающихся: дети сами, используя «лайки», оценивают качество ответов и комментариев одноклассников, креативность в представлении результатов и т. д.

Многие подростки проводили собственные прямые эфиры, в которых демонстрировали результаты своей работы, ряд обучающихся монтировали видеосюжеты-презентации, выкладывая их в igtv-формате.

YouTube - видеохостинг, предоставляющий пользователям услуги хранения, доставки и показа видео. YouTube стал популярнейшим видеохостингом и вторым сайтом в мире по количеству посетителей. Данный ресурс позволяет предоставить обучающимся неограниченный доступ к интересующим видеосюжетам, раскрывающих межпредметный потенциал рассматриваемых на уроке вопросов.

Таким образом, можно отметить, что использование социальных сетей и YouTube-канала в качестве дополнительных «платформ» для организации дистанционного обучения достаточно эффективно. Данная работа повышает мотивацию подростков к занятиям в рамках предметной области «Технология», создает условия для максимально эффективной презентации результатов деятельности. Мы считаем, что работа в данном направлении должна быть продолжена: реализация межпредметных связей технологии с другими дисциплинами с использованием социальных сетей и YouTube станет систематическим и дополнит традиционный формат обучения.

\section{Список литературы}

1. Федеральный государственный стандарт основного общего образования [Электронный ресурс]. - Режим доступа: https://fgos.ru/ (дата обращения: 10.01.2020).

2. Социальная сеть «Вконтакте» [Электронный ресурс]. - Режим доступа: https://ru.wikipedia.org/wiki/ВКонтакте

3. Социальная сеть Инстраграм [Электронный ресурс]. - Режим доступа: https://checkroi.ru/blog/chto-takoe-instagram/ 
Для заметок 
Для заметок 
Для заметок 
Учебное издание

\section{ЛУЧШИЕ ПРАКТИКИ «ВЫЗОВ ЦИФРОЙ» ПО ПРЕДМЕТНЫМ ОБЛАСТЯМ «МАТЕМАТИКА», «ИНФОРМАТИКА», «ТЕХНОЛОГИЯ»}

Методическое пособие

г. Чебоксары, 2020 г.

Редколлегия: Е.А. Мочалова, Т.Ю. Андреева Компьютерная верстка Е.В. Кузнецова

Подписано в печать 16.11.2020 г. Дата выхода издания в свет 19.11.2020 г.

Формат 60×84/16. Бумага офсетная.

Печать офсетная. Гарнитура Times. Усл. печ. л. 5,3475.

Заказ К-759. Тираж 500 экз.

Центр научного сотрудничества «Интерактив плюс»

428005, Чебоксары, Гражданская, 75

88007750902

info@interactive-plus.ru

www.interactive-plus.ru

Отпечатано в Студии печати «Максимум»

428005, Чебоксары, Гражданская, 75

+7 (8352) 655-047

info@maksimum21.ru

www.maksimum21.ru 